\title{
New interpretations of the phylogeny and taxonomy of delthyridoid spiriferids (Brachiopoda, Lower and Middle Devonian)
}

\author{
MENA SCHEMM-GREGORY
}

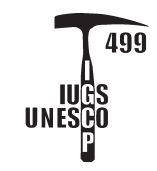

\begin{abstract}
A new phylogeny is introduced for Lower and Middle Devonian delthyridoid spiriferids with plicated fold and sulcus and bifurcating and trifurcating ribs. The new interpretation is based on side-by-side comparison of the type species of the genera with special focus on the micro-ornamentation and the style of ribbing, especially in the sulcus. During the revision of this group the following taxa are proposed: Multispiriferidae fam. nov, Ovetensispirifer novascotianus gen. et sp. nov., Turcispirifer turciae gen. et. sp. nov.; three taxa are described in open nomenclature: gen. nov. A, ?Turcispirifer sp. A, and Ovetensispirifer cf. ovetensium. In the systematic part, each genus is described including its type species of the studied group. Emended diagnoses from family to species level are given. As a consequence of this study, the geographic distribution of the taxa of each evolutionary branch emphasizes the endemicity present during Early Devonian time and its decline at the beginning of the Middle Devonian. However, on the other hand, faunal pathways are shown from Western Europe to Nova Scotia, from North Africa over Turkey to Eastern Asia and to Arctic Canada, and probably from Venezuela to North Africa. - Key words: Delthyridoidea, Spiriferida, Brachiopoda, phylogeny, palaeobiogeography, Devonian.
\end{abstract}

SCHEMM-GREGORY, M. 2008. New interpretations of the phylogeny and taxonomy of delthyridoid spiriferids (Brachiopoda, Lower and Middle Devonian). Bulletin of Geosciences 83(4), 401-448 (29 figures, 3 tables). Czech Geological Survey, Prague. ISSN 1214-1119. Manuscript received September 22, 2008; accepted in revised form November 24, 2008; issued December 31, 2008.

Mena Schemm-Gregory, Forschungsinstitut und Naturmuseum Senckenberg, Paläozoologie III, Senckenberganlage 25, D-60325 Frankfurt am Main, Germany; Mena.Schemm-Gregory@senckenberg.de

Delthyridoid spiriferids are an important tool for Devonian biostratigraphy and have been studied for almost two centuries. However, their systematics and their relationships to different faunal provinces during the Early Devonian are still a matter of debate. The systematics and phylogenetic interpretations introduced in this work are an attempt to elucidate the relationships between delthyridoid spiriferids showing the characters of the plicated fold and sulcus as well as bifurcation and trifurcation of ribs. Previous phylogenetic analyses are in most cases based on comparisons of literature. Bad illustrations and poor understanding of language used in original publications complicated the work. The result is often an erroneous report of the same genus from different faunal provinces (e.g., Solle 1953, 1971; Boucot 1959; Wang \& Rong 1986). Nevertheless, phylogenetic studies restricted to certain areas of one faunal province are of importance for consideration of global connections and evolutionary lineages for certain genera (e.g., Gourvennec 1989, Carls et al. 1993, Jansen 2001a).

In the first edition of the Treatise on Invertebrate Paleontology, Pitrat (1965) tried to establish systematics for the whole group of spiriferids and spread the genera considered in the present work through the whole Delthyridoidea Phillips, 1841 and Cyrtioidea Frederiks, 1924. In the following years several new taxa were established. Carter et al. (1994) published the preliminary version of the revised Treatise on Invertebrate Paleontology and made an attempt to revise the systematics of spiriferid delthyridoid brachiopods. Since its publication this work has been considered controversial in several ways and is characterised by certain mistakes in the diagnoses of genera, resulting in erroneous taxonomy (e.g., Jansen 2000, 2001a, b; Schemm-Gregory 2007, 2008c, in press). Most of these errors were unfortunately adopted in the next Treatise on Invertebrate Paleontology edition (Johnson \& Hou 2006, Gourvennec \& Carter 2007). Further works that do help to clarify the systematics and the palaeobiogeographical relationships of spiriferids on a global scale are, for example, Boucot (1975), Boucot \& Blodgett (2001), and Talent et al. (2001).

In this work genera from different regions, North America, Europe, North Africa, Central Asia, and South China (Fig. 1), are compared side-by-side for the first time and are, 


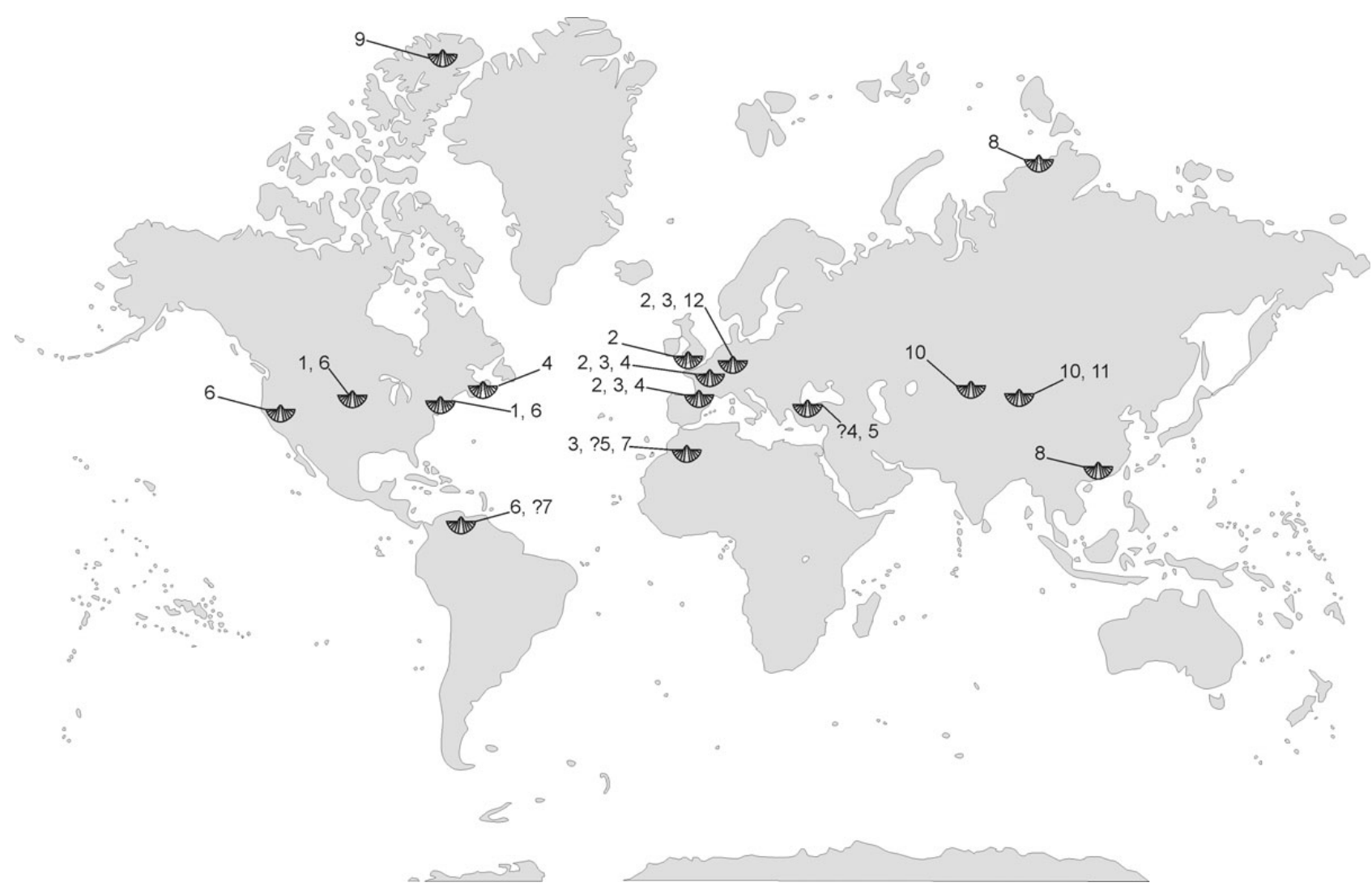

Figure 1. Occurrences of genera studied. 1 - Fimbrispirifer, 2 - Struveina, 3 - Vandercammenina, 4 - Ovetensispirifer, 5 - Turcispirifer, 6-Costispirifer, 7 -Multiplicatispirifer, 8 - Elymospirifer, 9 - Perryspirifer, 10 - Borealispirifer, 11 - gen. nov. A, 12 - Multispirifer.

where necessary, revised. Emended and new diagnoses are given for the taxa studied. As a result, unravelling the taxonomy has led to a systematics more complicated than that given in the last Treatise on Invertebrate Paleontology (Johnson \& Hou 2006, Gourvennec \& Carter 2007) with the relationships of the evolutionary branches showing an independent development for each branch during the Early Devonian and migration tendencies since the Late Emsian.

For stratigraphic assignment of Lower Devonian faunas, different subdivisions of the Devonian stages are used. In Europe and North Africa the brachiopods studied occur in neritic facies and correlation is based on the regional stages 'Siegenian' and 'Emsian' in their classical sense. For eastern North America the regional division into 'Oriskanian' and 'Onondagan' is used, although these units are still not confidently correlated to the GSSP (= Global Boundary Stratotype Sections and Points). In all other regions, if not indicated, the stages 'Pragian' and 'Emsian' are used in the GSSP sense (Gradstein et al. 2004).

\section{Material and methods}

The material is preserved as internal or external moulds of single or articulated specimens, and also as articulated or single shells. Fragments of shell material have been treated with formic acid to study micro-ornamentation impressions. Latex casts of external and internal moulds were made to study the shell morphology of the specimens. Drawings were done with the help of a camera lucida. Measurements were taken with digital calliper and rounded to $0.1 \mathrm{~mm}$. Specimens were coated with magnesium oxide prior to photographing.

\section{Institutional abbreviations}

AMNH: American Museum of Natural History, New York City, USA; D: Centre des Sciences de la Terre, Lyon, France; DEVEC-TR: General Directorate of Mineral Research and Exploration, Ankara, Turkey; FMNH PE: The Field Museum of Natural History, Chicago, USA; GZG.INV.: Geowissenschaftliches Zentrum der Universität Göttingen, Museum, Germany; IPB: Institut für Paläontologie, Universität Bonn, Germany; IV: National Geological Museum of China, Beijing, PR China; MB.B.: Museum für Naturkunde Berlin, Germany; Mbg.: Institut für Geologie und Paläontologie, Philipps Universität Marburg, Germany; MCZ: Museum of Comparative Zoology/Harvard University, Cambridge, Massachusetts, 


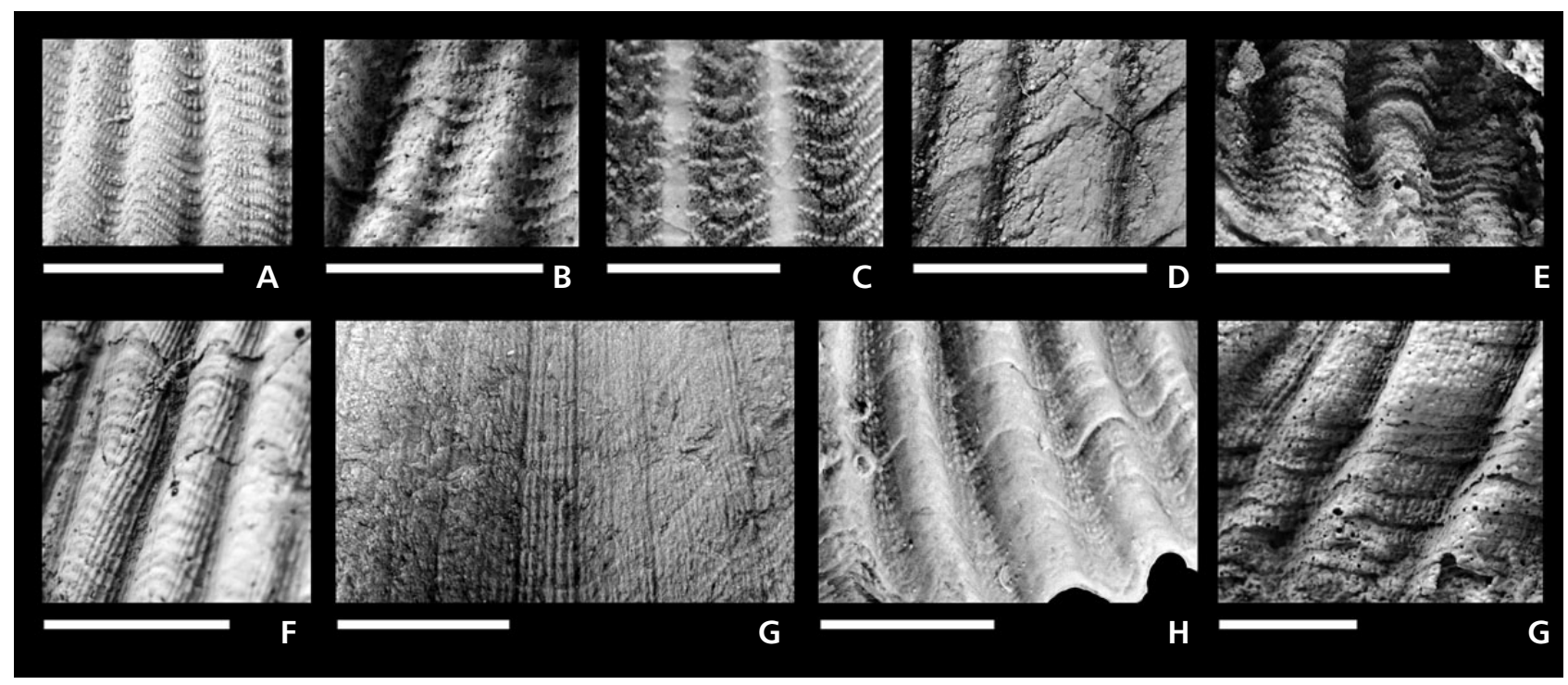

Figure 2. Micro-ornamenation of taxa studied. Scale bar represents $2 \mathrm{~mm}$. A - FMNH PE 60773. Fimbrispirifer divaricatus (Hall, 1867). B - SMF 19706. Struveina daleidensis (Steininger, 1853). $\bullet$ C - SMF 50452. Vandercammenina trigeri (de Verneuil, 1850). $\bullet$ D - Mbg. 5133. Turcispirifer turciae gen. et sp. nov. $\bullet$ E - PC 340. Ovetensispirifer ovetensium (Carls, 1986). $•$ F-SMF 66484b. Multiplicatispirifer foumzguidensis Schemm-Gregory, 2008c. $\bullet$ G - NYSM 17687. Costispirifer arenosus (Conrad, 1839). $\bullet$ H - SMF 66618. Elymospirifer kwangsienis (Hou, 1959). $\bullet$ I - SMF 66336. Multispirifer solitarius (Krantz, 1857).

USA; NHM: The Natural History Museum, London, UK; NIGP: Nanjing Institute of Geology and Palaeontology, Nanjing, PR China; NS: Geological Museum of Ministry of Geology and Mineral Resources, Beijing, PR China; NYSM: New York State Museum, Albany, USA; PC: private collection of Prof. Dr. Peter Carls, Technische Universität Braunschweig, Germany; PMO: Palaeontological Museum, Oslo, Norway; PZ: Museo del Departamento de Palaeontología de la Universidad Zaragoza, Spain; SMF: Forschungsinstitut und Naturmuseum Senckenberg, Frankfurt am Main, Germany; SKGS: South Kazakhstan Geological Survey, Tashkent; UA: University of Alberta, Canada; USNM: Smithsonian Institution/National $\mathrm{Mu}-$ seum of Natural History, Washington DC, USA; YPM: Peabody Museum/Yale University, New Haven, USA.

\section{Important morphological features}

For a reasonable and probable reconstruction, morphological features have to be considered in relation to their importance. Some characters were created at the beginning of the evolutionary development of the group and did not change through the phylogeny of a certain group whereas others appeared several times in certain branches and/or were lost after a while. To judge the value of each morphologic character in the delthyridoid spiriferids a careful study of extensive material was made. In the following section, certain morphologic characters important for the interpretation of the phylogeny are briefly described.
Micro-ornamentation. - Two types of micro-ornamentation, fimbriate and capillate, are present in the material studied (Fig. 2). Fimbriate micro-ornamentation consists of rows of micro-spines at the edge of each growth lamella whereas capillate micro-ornamentation shows capillae on the surface that are crossed by the growth lamellae. In some genera micro-spines are also developed in capillate micro-ornamentation. All fimbriate genera studied in this work show single rows of micro-spines at the edge of each growth lamella, but as more than one row of micro-spines appear in other genera (Schemm-Gregory in press), the single row of micro-spines is emphasized in the diagnoses and descriptions. In this work, the fimbriate type is considered as the initial micro-ornamentation taken over from ancestral howellellid forms. The capillate micro-ornamentation is interpreted to have developed out of a fimbriate microornamentation. However, capillate micro-ornamentation has been developed independently several times among different groups of spiriferids, e.g., Filispiriferidae Schemm-Gregory, 2008a, Eospiriferinae Schuchert, 1929. The author collected and studied specimens of Howellella elegans (Muir-Wood, 1925), the type species of Howellella Kozłowski, 1946 from the type locality Djubvik, Gotland (Sweden). These specimens show a well-developed fimbriate micro-ornamentation (Fig. 3) and are considered to be the root of the spiriferids studied (see section Phylogenetic interpretations and palaeobiogeography).

Ribs. - The radial ridges of the coarse ornamentation are described in this work as ribs. According to Williams \& Brunton (1997), ribs describe any ornament of radial ridges; 


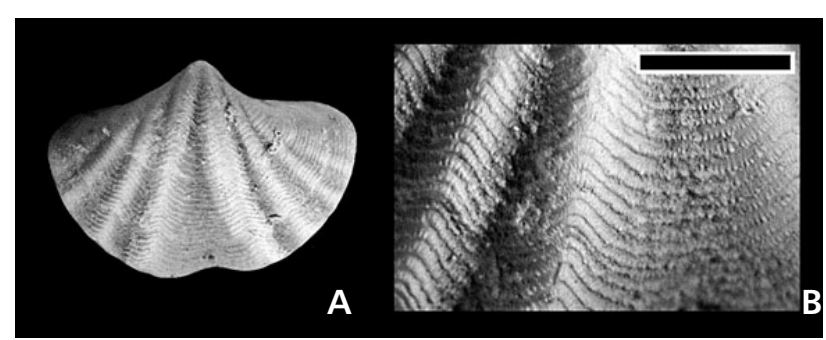

Figure 3. Micro-ornamentation of Howellella elegans (Muir-Wood, 1925), SMF 66933. Articulated specimen. Locality: Djubvik, Gotland (Sweden). Stratum: Upper Mulde Formation, Wenlock (Middle Silurian). - A - plan view on ventral valve $(\times 3.0)$. $\bullet$ B - Detailed view on micro-ornamentation. Scale bar represents $2 \mathrm{~mm}$.

costae, however, is the term for "first-formed radial ridges on external surface of brachiopod shell" (Williams \& Brunton 1997, p. 427) or coarse ribs in general, costellae are fine ribs, and capillae very fine ribs. A third term for characterising coarse ornamentation is plication. Plications are major undulations of the commissure that are reflected on the shell interior. As the differentiation between costa, costella, and capilla is subjective and these terms are often used in different senses, the neutral term 'ribs' is used in this work.

To describe bifurcation and trifurcation patterns, ribs of first, second, and third order are distinguished. Ribs of first order are the main ribs before multiplication; those of second order have bifurcated or trifurcated ribs for the first time, whereas third order ribs have multiplied twice during ontogeny. The style of ribbing is different in each taxon on the external surface either on flanks and/or in sulcus and on the fold (Fig. 4). For certain taxa no adequate or well-enough preserved material was available to give a reliable number of ribs on flanks. After all the number of ribs on flanks varies strongly during ontogeny due to the multiplication.

Dividing ribs in the sulcus. - The scheme of dividing ribs in the sulcus can also be used as a tool for determination at genus level (Fig. 5). Important characters are the median rib in the sulcus and the growth stage in which furcation occurs, as well as the rib that is dividing.

Development of secondary shell material. - Some genera of spiriferids are characterized by strong development of secondary shell material in the apical region, probably to stabilize the life position of the upwards-oriented anterior margin of the shells (Jansen 2001a). As a result, the ventral muscle field is deeply impressed in the shell material and the dental plates are embedded into shell material and may not be preserved on the internal mould (e.g., Costispirifer).

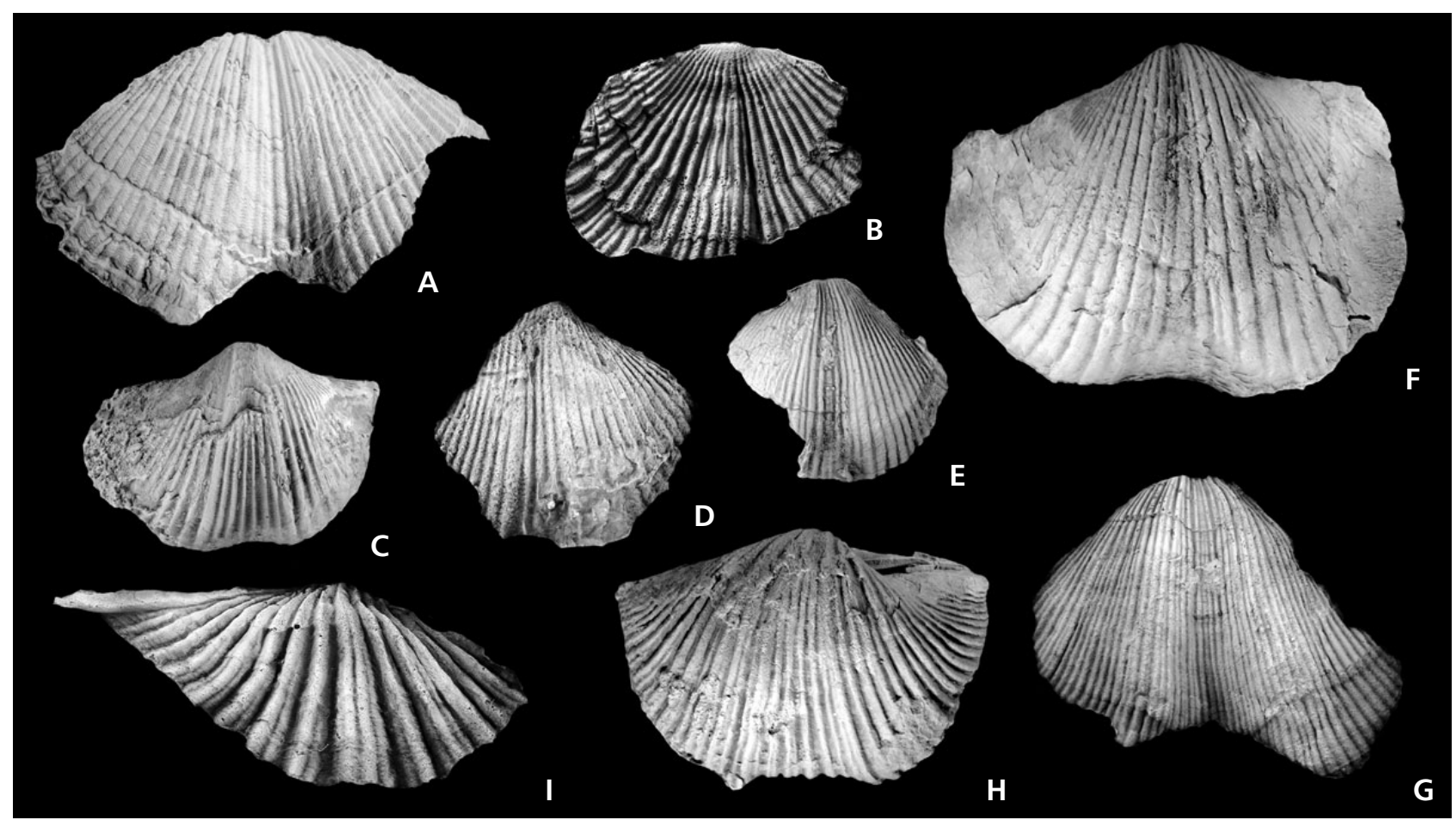

Figure 4. External shells showing multiplication of ribs of taxa studied. All figures are in original size (x 1.0) • A - FMNH PE 60773. Fimbrispirifer divaricatus Hall, 1867. • B - SMF 19706. Struveina daleidensis (Steininger, 1853). • C - SMF 50452. Vandercammenina trigeri (de Verneuil, 1850). $\bullet$ D - PC 340. Ovetensispirifer ovetensium (Carls, 1986). • E - Mbg. 5133. Turcispirifer turciae gen. et sp. nov. • F - YPM 221339. Costispirifer arenosus (Caster, 1839). • G - SMF 66484b. Multiplicatispirifer foumzguidensis Schemm-Gregory, 2008c. • H - SMF 66618. Elymospirifer kwangsienis (Hou, 1959). • I - SMF 66336. Multispirifer solitarius (Krantz, 1857). 
In genera that do not show much development of secondary shell material, the dental plates leave long and mostly thin slits on either side of the filling of the ventral muscle field on the internal mould. Strong development of secondary shell material in the dorsal apical region results in free exposed cardinalia whereas in taxa with less development of secondary shell material the cardinalia are hidden beneath the filling of the dorsal umbo on the internal mould.

Crural plates. - Crural plates are connected with the dorsal valve floor. However, until they are completely embedded into shell material several crural stages are visible (see Gourvennec 1989, p. 29, fig. 16). Juvenile specimens have to be studied to see if the crural plates are free lying and if they become embedded during ontogeny. The presence or absence of crural plates is a genus level character.

Delthyrium, deltidial lamellae, and deltidium. - The Delthyridoidea are characterised by an open delthyrium that may be restricted by a pair of deltidial lamellae. The thickness and orientation of these lamellae is regarded as a taxonomically important character (Schemm-Gregory in press). The deltidial lamellae can also be fused in the apical region forming a small deltidium.

Ctenophoridium and notothyrial shelf. - The term ctenophoridium describes the dorsal diductor field and consists of lamellae orientated in longitudinal direction. Some authors (e.g., Gourvennec 1989, Jansen 2001a) regard the number of these lamellae as an important character for systematic description, but in most cases, the preservation of internal moulds is quite poor and the lamellae are abraded, which can give the wrong impression of their number. Nonetheless, the number of lamellae indicates tendencies in phylogeny.

The ctenophoridium can be supported by a notothyrial shelf. Presence or absence of the notothyrial shelf is an important character. The absence of the shelf results in an orientation of the surface of the ctenophoridium perpendicular or oblique to the commissural plane whereas its presence is seen in a ridge on the internal mould posterior and/or beneath the filling of the dorsal umbo on the internal mould. If the ctenophoridium lies on this ridge, it is oriented parallel to the commissural plane.

\section{Phylogenetic interpretations and palaeobiogeography}

The root of the delthyridoid spiriferids probably lies in the fimbriate Howellella (Iberohowellella) Carls, 1985, as already discussed by Carls et al. (1993), from which Vandercammenina Boucot, 1975 separated. Vandercammenina, especially the early form $V$. sollei Carls, 1986 shows few ribs in the sulcus and on the fold and clearly developed crural
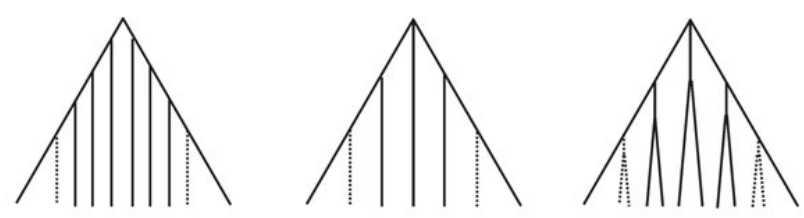

Vandercammenina trigeri

Ovetensispirifer ovetensium Struveina daleidensis

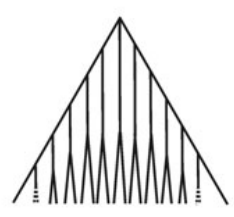

Fimbrispirifer venustus

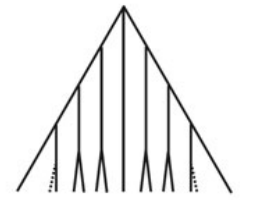

Elymospirifer kwangsiensis

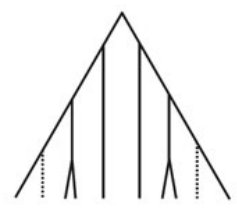

Borealispirifer bifurcatus

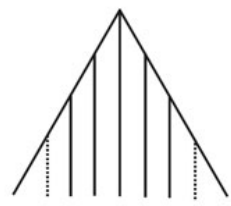

Turcispirifer turciae

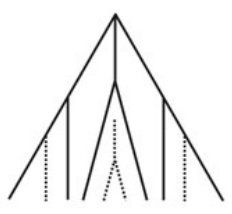

Costispirifer arenosus

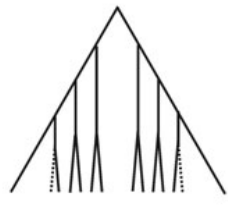

Perryspirifer scheii

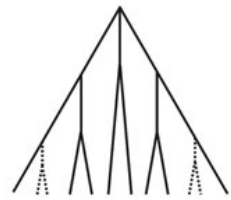

Gen. nov. A maximus
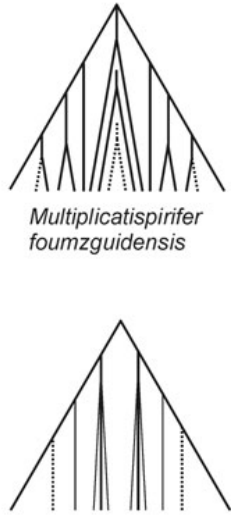

Multispirifer solitarius
Figure 5. Scheme of splitting of ribs in the sulcus of genera studied. Dotted lines describe the next ontogenetic stage.

plates. Later in the evolutionary lineage of Vandercammenina the number of ribs in sulcus and fold increases. Especially in the type species, V. trigeri (de Verneuil, 1850), a development of secondary shell material in the dorsal apical region can be noted resulting in embedded crural plates. During the Siegenian, Struveina Boucot, 1975 separated from Vandercammenina, a genus characterized by bifurcation and trifurcation of ribs on the flanks as well as in the sulcus and on the fold but also in the lack of crural plates in all of its species. Fimbrispirifer Cooper, 1942 has been found at the beginning of the Eifelian in North America. This genus is interpreted, even though crural plates are present, as being a descendent from the North African/European Struveina rather than from Vandercammenina because of the strong bifurcation and trifurcation of ribs. Migration of Fimbrispirifer might have been possible with sea-level rise at the beginning of the Eifelian (Johnson et al. 1985). Struveina became extinct during Emsian time in the classical German sense; Vandercammenina during the Eifelian.

Another lineage arising from the African forms of Vandercammenina is represented by the new genera described 
Table 1. Comparison of the fimbriate genera studied with ribbed fold and sulcus and bifurcating and trifurcating ribs on flanks, fold, and in sulcus

\begin{tabular}{|c|c|c|c|c|c|}
\hline & $\begin{array}{l}\text { Fimbrispirifer } \\
\text { Cooper, } 1942\end{array}$ & $\begin{array}{c}\text { Struveina } \\
\text { Boucot, } 1975\end{array}$ & $\begin{array}{l}\text { Vandercammenina } \\
\text { Boucot, } 1975\end{array}$ & $\begin{array}{l}\text { Ovetensispirifer } \\
\text { gen. nov. }\end{array}$ & $\begin{array}{l}\text { Turcispirifer } \\
\text { gen. nov. }\end{array}$ \\
\hline septal pillow & - & - & small & large & + \\
\hline dental plates & divergent & divergent & divergent & divergent & almost parallel \\
\hline ventral muscle field & weakly impressed & weakly impressed & moderately impressed & strongly impressed & weakly impressed \\
\hline median rib in sulcus & + & $+1-$ & - & + & + \\
\hline notothyrial shelf & - & - & - & lacking or indicated & indicated in some cases \\
\hline dental sockets & thin & thick & thin & thick & thin \\
\hline brachiophores & thin, small & thick, small & thin, small & thin, long & thin, ? \\
\hline crural plates & + & - & $+/-$ & + & + \\
\hline bicurcation of costae on flanks & + & + & rarely & - & - \\
\hline trifurcation of costae on flanks & + & + & - & - & - \\
\hline deltidium & - & - & - & - & - \\
\hline geographic occurrence & eastern North America & Europe & North Africa, Europe & Europe & Turkey, ?Morocco \\
\hline stratigraphic occurrence & $\begin{array}{l}\text { Emsian to Lower } \\
\text { Givetian }\end{array}$ & $\begin{array}{l}\text { Lower Siegenian } \\
\text { to Middle Eiflian }\end{array}$ & $\begin{array}{l}\text { Lower Siegenian } \\
\text { to Middle Eifelian }\end{array}$ & Siegenian & Siegenian to ?Emsian \\
\hline
\end{tabular}

here, Ovetensispirifer and Turcispirifer. They are interpreted as being descendents of Vandercammenina because of the presence of crural plates and fimbriate micro-ornamentation and the absence of bifurcating ribs on the flanks. Ovetensispirifer appears during the early Siegenian in the Iberian Chains (Spain) and Nova Scotia (Canada), probably also in the Istanbul Basin, Turkey (U. Jansen, pers. comm. 2008); Turcispirifer appears in Turkey and probably in Morocco during the Siegenian. The vandercammeninid ancestor of Ovetensispirifer might be close to $V$. sollei because of the small number of ribs in the sulcus and the development of crural plates that both, Ovetensispirifer and $V$. sollei show. Ovetensispirifer novascotianus sp. nov. from Nova Scotia clearly shows a faunal relationship to Ovetensispirifer ovetensium from the Iberian Chains and the Armorican Massif (France) of the Rhenish-Bohemian Region during Siegenian time based on its strong development of secondary shell material in the apical region of both valves and the elevated internal mould of the ventral muscle field. Additional brachiopods that occur together with O. novascotianus in North America are Crassirensselaeria sp. and ?Brachyspirifer aff. crassicosta (Boucot 1960a, b), but these forms are related to taxa occurring in the Ardenno-Rhenish Mountains (Belgium, Germany) of the Rhenish-Bohemian Region. Species of Turcispirifer found in Turkey show faunal affinities to North African faunas of Early Devonian age (Schemm-Gregory 2008a, b) whereas affinities between Turkey and Central Europe (e.g., de Verneuil 1869, Paeckelmann \& Sieverts 1932) turn out to be suspect. Recent studies on the palaeogeography of the Rheic Ocean show that faunal exchange seems to have been more plausi- ble between the Istanbul Basin (present day Turkey), which was then situated at the southern margin of Baltica, and North Gondwana (present day North Africa) than between the Istanbul Basin and Avalonia (present day Central Europe) (U. Linneman, pers. comm. 2008). Table 1 shows the morphological comparison of fimbriate genera discussed.

The Asian Emsian (sensu GSSP; Gradstein et al. 2004) forms that are characterised by a capillate micro-ornamentation, and in some genera also with micro-spines of different length, probably developed out of the Turkish Turcispirifer with slow-eastwards migration. The group around Borealispirifer Hou \& Su in Su \& Hou, 1993 that appears in Central and East Asia during the Emsian in GSSP sense shows relatively narrow ribs, but has bifurcation and trifurcation on the flanks as well as in the sulcus and on the fold. However, the Turkish forms show only bifurcation of ribs in the sulcus and on the fold. The occurrence of capillae with micro-spines is interpreted as a development from fimbriate to capillate micro-ornamentation. During the Early Emsian Elymospirifer Wang in Wang et al., 1974, a South Chinese and Taimyr form, probably evolved out of Borealispirifer and gave rise to the Late Emsian Perryspirifer Jones \& Boucot, 1983, which possibly migrated further eastwards with the sea-level rise at the Early/Late Emsian boundary interval (Johnson et al. 1985) from South China to the Canadian Arctic Islands.

The morphology of the European genus Multispirifer Kaplun, 1961 is quite distinct from all other genera studied in this work. A possible phylogenetic link to a potential ancestor is still missing. Its origin from an early Siegenian 
Mena Schemm-Gregory • Phylogeny and taxonomy of delthyridoid spiriferids

Table 2. Comparison of the capillate genera studied with ribbed fold and sulcus and bifurcating and trifurcating ribs on flanks, fold, and in sulcus

\begin{tabular}{|c|c|c|c|c|c|c|c|}
\hline & \multicolumn{2}{|c|}{$\begin{array}{c}\text { Costispiriferidae } \\
\text { Termier \& Termier, } 1949\end{array}$} & \multicolumn{4}{|c|}{ Elymospiriferidae Johnson \& Hou in Carter et al., 1994} & \multirow{2}{*}{$\begin{array}{c}\begin{array}{c}\text { Multispiriferidae } \\
\text { fam. nov. }\end{array} \\
\text { Multispirifer } \\
\text { Kaplun, } 1961\end{array}$} \\
\hline & $\begin{array}{l}\text { Costispirifer } \\
\text { Cooper, } 1942\end{array}$ & $\begin{array}{l}\text { Multiplicatispirifer } \\
\text { gen. nov. }\end{array}$ & $\begin{array}{c}\text { Elymospirifer } \\
\text { Wang in Wang } \\
\text { et al., } 1974\end{array}$ & $\begin{array}{c}\text { Perryspirifer } \\
\text { Jones \& Boucot, } \\
1983\end{array}$ & $\begin{array}{c}\text { Borealispirifer } \\
\text { Hou \& Su in Su \& } \\
\text { Hou, } 1993\end{array}$ & gen. nov. A & \\
\hline outline & megathyrid & megathyrid & megathyrid & megathyrid & megathyrid & megathyrid & brachythyrid \\
\hline septal pillow & - & + & - & + & $?$ & $?$ & + \\
\hline dental plates & divergent & $\begin{array}{l}\text { divergent to almost } \\
\text { parallel }\end{array}$ & divergent & divergent & divergent & almost parallel & divergent \\
\hline ventral muscle field & $\begin{array}{l}\text { strongly } \\
\text { impressed }\end{array}$ & weakly impressed & $\begin{array}{l}\text { moderately } \\
\text { impressed }\end{array}$ & $\begin{array}{l}\text { strongly } \\
\text { impressed }\end{array}$ & weakly impressed & $\begin{array}{l}\text { strongly } \\
\text { impressed }\end{array}$ & $\begin{array}{l}\text { strongly } \\
\text { impressed }\end{array}$ \\
\hline $\begin{array}{l}\text { median open } \\
\text { in sulcus }\end{array}$ & + & + & + & - & - & + & - \\
\hline notothyrial shelf & - & - & - & $?$ & $?$ & $?$ & + \\
\hline dental sockets & thin & thick & thin & thin & thin & $?$ & thick \\
\hline brachiophores & thin, small & thick, small & thin, small & thin, long & $?$ & $?$ & thick, long \\
\hline crural plates & - & - & + & + & + & + & - \\
\hline $\begin{array}{l}\text { bicurcation of costae } \\
\text { on flanks }\end{array}$ & - & - & + & + & + & + & + \\
\hline $\begin{array}{l}\text { trifurcation of costae } \\
\text { on flanks }\end{array}$ & - & - & + & + & + & - & + \\
\hline deltidium & + & - & + & $?$ & $?$ & $?$ & + \\
\hline geographic occurrence & $\begin{array}{l}\text { eastern North } \\
\text { America }\end{array}$ & North Africa & $\begin{array}{l}\text { Taimyr, South } \\
\text { China }\end{array}$ & $\begin{array}{l}\text { Canadian Arctic } \\
\text { Islands }\end{array}$ & $\begin{array}{l}\text { Kazakhstan, } \\
\text { northern China }\end{array}$ & northern China & Central Europe \\
\hline stratigraphic occurrence & Oriskanian & Emsian & Lower Emsian & Upper Emsian & Lower Emsian & Lower Emsian & Siegenian \\
\hline
\end{tabular}

form of Vandercammenina might be a reasonable possibility. The phylogenetic lineage of this genus is characterized by large forms with 'bundled' ribs, cardinalia situated on an elevated shelf, and a capillate micro-ornamentation that can also show micro-spines and is considered in this work to be an isolated evolutionary branch. Multispirifer became extinct before the Early Emsian in the classical German sense. However, this interpretation is still a matter of debate.

The family Costispiriferidae shows a capillate micro-ornamentation without micro-spines and is interpreted to have evolved from early forms of Vandercammenina. The reason for the restricted appearance of Costispiriferinae in North America and the local appearance of Multiplicatispiriferinae in Morocco remains speculative and is probably the result of incomplete preservation. However, relationships between the Anti-Atlas (Morocco) and the Appalachian Chain (eastern North America) have already been discussed, e.g., Michard (1976). ?Multiplicatispirifer weisbordi (Harris in Liddle et al., 1943) from Venezuela might represent the phylogenetic link between Costispirifer Cooper, 1942 and Multiplicatispirifer Schemm-Gregory, 2008c. In the present state of research, it is assumed that Multiplicatispiriferinae evolved out of Costispiriferinae and Schemm-Gregory (2008c) provided an attempt to reconstruct their phylogenetic relationships and migration pathways. Table 2 shows a morphological comparison of the discussed capillate genera. The interpretation of the discussed phylogenetic relationship is shown in Fig. 6.

\section{Systematic palaeontology}

Order Spiriferida Waagen, 1883

Suborder Delthyridina Ivanova, 1972

Superfamily Delthyridoidea Phillips, 1841

Family Fimbrispiriferidae Pitrat, 1965

Type genus. - Fimbrispirifer Cooper, 1942.

Emended diagnosis. - Shells with ribbed fold, sulcus, and flanks; ribs multiply by bifurcation and trifurcation; crural plates variably present. Micro-ornamentation fimbriate with single rows of micro-spines on the edge of each growth lamella. 


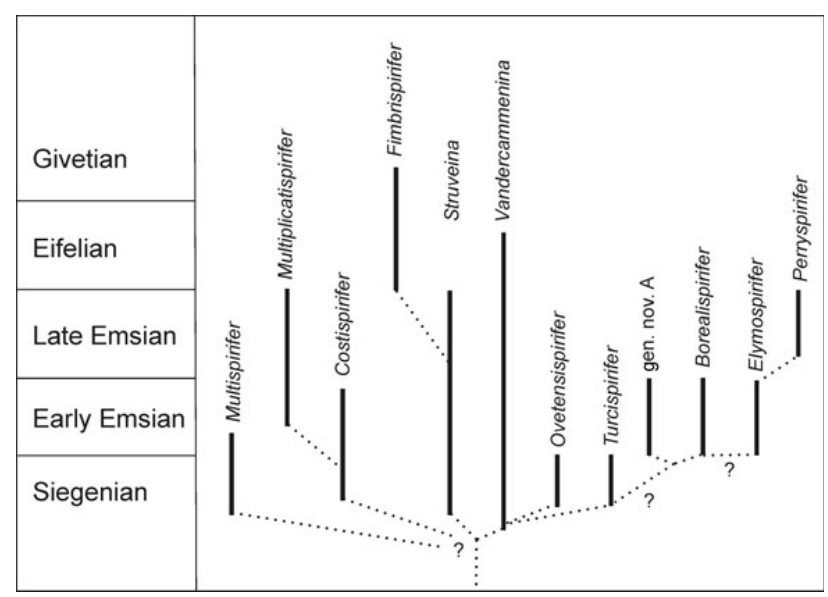

Figure 6. Proposed phylogenetic tree of delthyridoid spiriferids with ribbed fold, and sulcus as well as bifurcating and trifurcating ribs on flanks, fold, and in the sulcus. Stratigraphic stages are used in the classical German sense.

Geographic and stratigraphic occurrence. - Eastern and central North America, North Africa, Western and Central Europe, Turkey; Siegenian to lower Givetian (middle Lower Devonian to upper Middle Devonian).

Genera assigned. - Fimbrispirifer Cooper, 1942, Struveina Boucot, 1975, Vandercammenina Boucot, 1975, Turcispirifer gen. nov., Ovetensispirifer gen. nov.

Genera excluded. - Bultynckia García-Alcalde, 2004.

Remarks. - The Fimbrispiriferidae is raised to family level as published in the former Treatise on Invertebrate Paleontology (Pitrat 1965). The consideration that the Fimbrispiriferinae is a subfamily of the Hysterolitidae Termier \& Termier, 1949 is erroneous as the Hysterolitidae are defined as having a smooth fold and sulcus, occasionally with a median furrow or rib as already pointed out in (Schemm-Gregory in press). The distinct scheme of ribbing on flanks, fold, and sulcus in comparison to other delthyridoideans (Fig. 5) justifies the family following also the intention of other authors (Termier \& Termier 1949).

Discussion. - The genus Bultynckia García-Alcalde, 2004 is excluded from the Fimbrispiriferidae due to its style of ribbing. It shows bifurcation of ribs only on flanks at the anterior margin and only in some cases a rib on the walls of the sulcus. Furthermore, the fold and sulcus are rather flat on its top or bottom, sometimes showing a very coarse median rib or a broad, but shallow furrow that shows a very different style from the scheme of ribbing on the sulcus and fold of the genera of Fimbrispiriferidae considered in this work. García-Alcalde (2004) discussed the differences of Bultynckia with Vandercammenina, Struveina, Fim- brispirifer, and Multispirifer. Until further material can be studied Bultynckia is referred to the Paraspiriferinae Pitrat, 1965, as was the suggestion of García-Alcalde (2004).

\section{Genus Fimbrispirifer Cooper, 1942}

Type species. - Spirifer venustus Hall, 1860, p. 62.

Emended diagnosis. - Medium to large, biconvex to ventribiconvex. Ventral interarea curved and apsacline. Fold, sulcus, and flanks with numerous bifurcating ribs; ribs on flanks may also trifurcate. Ribs and furrows are rounded in cross section. No deltidium, dental plates short and wedge-like. Crural plates present, notothyrial shelf and septal pillow lacking. Micro-ornamentation of closely spaced, zigzag concentric growth lamellae with single rows of micro-spines at their edges.

Species assigned. - Spirifer venustus Hall, 1860, Spirifer divaricatus Hall, 1867, Spirifer grieri Hall, 1867, Fimbrispirifer tricostatus Fagerstrom, 1961.

Remarks. - Cooper (1942, p. 231) originally defined Fimbrispirifer by its fimbriate micro-ornamentation (Fig. 2A), however, on most of the material, including the holotype of the type species, the micro-ornamentation is not preserved. Thus, various authors assigned spiriferids to Fimbrispirifer emphasizing their bifurcating ribs and ribbed fold and sulcus rather than by the micro-ornamentation, which is only preserved in rare cases (e.g., Amsden 1963, Brice 1982). Havlíček (1959) defined Fimbrispirifer by simple and bifurcating ribs and ribs on flanks, fold, and in sulcus with a fimbriate micro-ornamentation. Later, Boucot (1975) separated the genera Vandercammenina and Struveina from Fimbrispirifer based on the absence and presence of crural plates and the style of ribbing. In the present work, the concept of Boucot (1975) is followed and according to his and my own studies, "Fimbrispirifer" charybdis (Barrande, 1879) has to be excluded from Fimbrispirifer due to the lack of multiplying ribs. However, 'Fimbrispirifer'-like forms are reported from the upper Eifelian beds from Skaly (Holy Cross Mountains, Poland: Halamski 2004, p. 207) but have not been considered here.

Discussion. - Fimbrispirifer differs from Struveina in its shorter dental plates, a narrower ctenophoridium, delicate cardinalia, and distinct crural plates which are always lacking in Struveina.

In contrast to Vandercammenina, Fimbrispirifer shows a thin ctenophoridium. The ctenophoridium in Vandercammenina is broader. Fimbrispirifer always has crural plates whereas in Vandercammenina the crural plates are either embedded into secondary shell material or indicated 
by a broad and rounded indentation beneath the filling of the ventral muscle field on the internal mould (Fig. 7; Gourvennec 1989, pl. 6, figs 22, 23). The ribs of Fimbrispirifer are bifurcating and trifurcating on the flanks, in Vandercammenina they bifurcate on the flanks only in very few specimens. Vandercammenina has in contrast to Fimbrispirifer no median rib in the sulcus.

The dental plates in Turcispirifer are long, thin, and oriented almost parallel to each other whereas they are small and divergent in Fimbrispirifer. A notothyrial shelf is always lacking in Fimbrispirifer, in Turcispirifer it can be indicated in some cases. Turcispirifer shows no bifurcation on its flanks whereas Fimbrispirifer shows bifurcating and trifurcating ribs on its flanks.

Ovetensispirifer differs from Fimbrispirifer in having much more secondary shell material developed in its apical region of both valves, a deeply embedded ventral muscle field, and longer dental plates. Ribs of Ovetensispirifer are bifurcating in the sulcus and on the fold in adult stages. The growth lamellae of Ovetensispirifer are at a greater distance from each other than growth lamellae in Fimbrispirifer.

Geographic and stratigraphic occurrence. - Eastern and central North America; Emsian to lower Givetian (upper Lower Devonian to upper Middle Devonian).

\section{Fimbrispirifer venustus (Hall, 1860)}

Figures 2A, 4A, 5, 7

1860 Spirifer venustus n. sp. - Hall, p. 82.

1942 Fimbrispirifer venustus (Hall, 1860). - Cooper, pp. 231, 232.

1944 Fimbrispirifer venustus (Hall, 1860). - Cooper in Shimer \& Shrock, p. 323, pl. 122, figs 32-34.

1983 Fimbrispirifer venustus (Hall, 1860). - Jones \& Boucot, pp. 333-336, fig. 2A-H.

Holotype. - Articulated shell, designated as lectotype by Jones \& Boucot (1983), stored under inventory number USNM 39489. Length $27.8 \mathrm{~mm}$, width $41.8 \mathrm{~mm}$, and thickness $24.4 \mathrm{~mm}$. A plaster cast of the holotype is stored under inventory number SMF 66613.

Type horizon and locality. - Beechwood Limestone, Hamilton Group, Givetian (upper Middle Devonian); Lebanon, Kentucky, USA.

Material.-Locality and stratum: Lebanon, Kentucky, USA.; Beechwood Limestone. 1 articulated specimen: USNM 39489 (holotype), 1 internal mould of articulated specimen USNM 39489a (paratype). Locality and stratu m: abandoned quarry $2.5 \mathrm{~km}$ SSE of Ragland, Alabama,

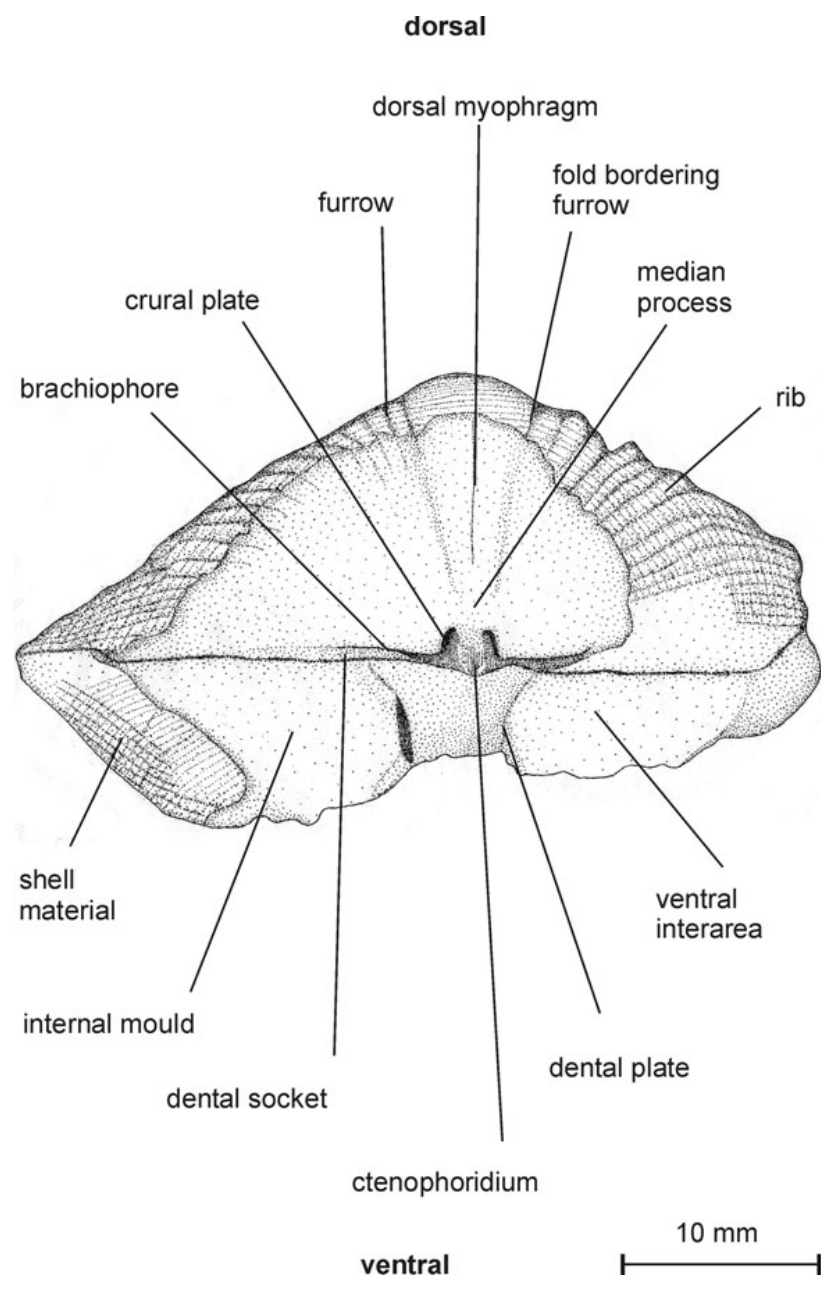

Figure 7. Morphological terms of Fimbrispirifer venustus (Hall, 1860), USNM 39489a, posterior view. Articulated specimens showing the internal mould in apical region. Crural plates, dental sockets, and dental plates are preserved as negative forms.

USA; Ragland Sandstone. 1 fragment of an external ventral mould: USNM 108217.

Emended diagnosis. - Shells medium-sized to large, transverse, and ventribiconvex in longitudinal section; megathyrid without mucronations. Fold and sulcus conspicuous with ribs bifurcating and trifurcating on flanks. Crural plates strong and well developed. Brachiophores and dental sockets delicate. Notothyrial shelf lacking. Growth lamellae at short distance to each other.

Description.-Form and size: shells medium-sized with bifurcating and trifurcating ribs on flanks. Outline semielliptic to subtriangular. Ex terior of ventral valve: interarea high, catacline to apsacline, and curved in the upper part. Delthyrium open. Deltidial lamellae and deltidium lacking. Sulcus broad and rounded in cross section. Ex terior of dorsal valve: interarea low and anacline. Fold 
moderately high. Coarse ornamentation: ribs unequally bifurcating and trifurcating on the posterior half of the flanks at the same growth stage. Each rib multiplies only once (Fig. 4A). Sulcus with median furrow. Ribs bifurcating to median from the sulcus bordering ribs always at the same growth stage (Fig. 5). Ribs on the fold bifurcating from the most lateral rib to median or from the first pair of rib to lateral. Ribs on fold and in sulcus are of same size as ribs on the flanks. All ribs fine, separated by fine furrows. Ribs and furrows rounded to angular in cross section. Micro-ornamentation: fimbriate, with single rows of micro-spines on the edge of each growth lamella. Growth lamellae well developed and close to each other. Interior of ventral valve: filling of the umbo extends to posterior over the hinge line. Almost no development of secondary shell material in apical region. Lateral apical cavities are clearly separated by dental plates from the central apical cavity. Fillings of the lateral apical cavities reaching to posterior over the hinge line almost as far as the internal mould of the ventral muscle field. Muscle field not embedded into shell material. Free portions of dental plates thin and moderately long. Ribs well impressed on the internal mould, bifurcation and trifurcation of ribs visible. Interior of dorsal valve: notothyrial shelf lacking. Ctenophoridium small, situated anterior of the hinge. Crural plates strong and long. Crural bases preserved as free lamellae or lacking. Dental sockets thin, long, and almost parallel to the hinge line. Brachiophores thin and small. Myophragm weakly developed, leaving a fine furrow in the anterior half of the internal mould. Adductor scars not preserved. Fold moderately elevated and rounded on top. Ribs well impressed on the internal mould, bifurcation and trifurcation of ribs visible.

Geographic and stratigraphic occurrence. - Eastern North America; lower Givetian (upper Middle Devonian).

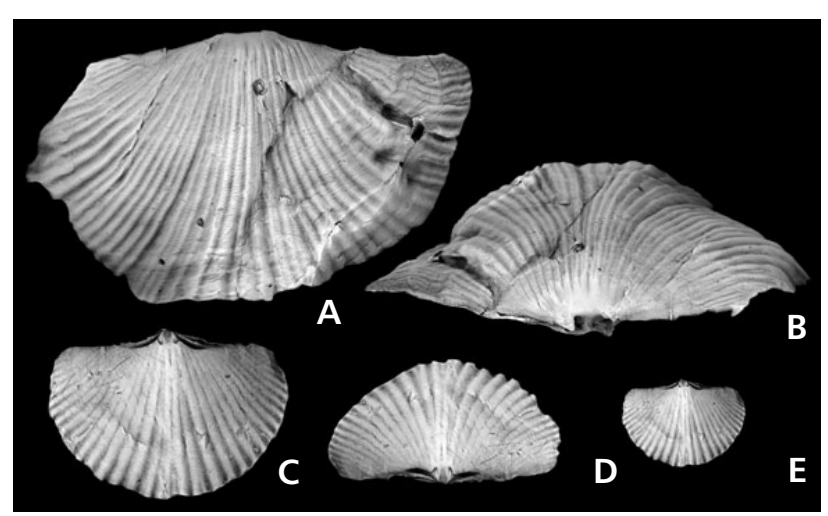

Figure 8. Vandercammenina parcefurcatus (Spriestersbach, 1915). Locality: Railway cut near Gummersbach, Bergisches Land (Rheinisches Schiefergebirge, Germany). Stratum: lower Selscheid Beds, Eifelian (lower Middle Devonian). • A, B - GZG.INV. 15222, internal dorsal mould (× 1.0). Plan (A) and oblique posterior (B) views. - C-E - GZG.INV. 15223, internal dorsal mould. Plan (C) and oblique posterior (D) views $(\times 2.0)$ and plan $(\mathrm{E})$ view $(\times 1.0)$.

\section{Genus Struveina Boucot, 1975}

Type species. - Spirifer Daleidensis Steininger, 1853, p. 71.

Emended diagnosis. - Medium-sized to large spiriferids with bifurcating and trifurcating ribs on sulcus, fold, and flanks. Ribs are rounded, furrows are angular to rounded in cross section. Crural plates and notothyrial shelf always lacking.

Species assigned. - Spirifer Daleidensis Steininger, 1853, Spirifer jouberti Oehlert \& Davoust, 1879, Spirifer ferronensis Compte, 1938.

Species excluded. - Spirifer parcefurcatus Spriestersbach, 1915.

Remarks. - The species parcefurcatus Spriestersbach, 1915 (Fig. 8) is excluded from Struveina due to the presence of well developed crural plates preserved as long slits on the internal dorsal mould and rare occurrence of bifurcating ribs on its flanks. A few specimens from the Selscheid Beds (lower Eifelian, lower Middle Devonian) of the material from Thienhaus (1940, GZG.INV. 15222-15226) and Schmidt \& Trunko (1965, GZG.INV. 15215-15221) show 1 or 2 bifurcating ribs next to the sulcus. The illustrated paratype by Spriestersbach (1915, pl. 14, fig. 10), a dorsal internal mould, shows weakly indicated crural plates and bifurcation of the first pair of ribs. Further material of this taxon from the lower Eifelian of the Sauerland region (Germany) has been studied by the present author in the collection of the Geowissenschaftliches Zentrum der Universität Göttingen, Museum. In this work the species parcefurcatus is assigned to the genus Vandercammenina.

Discussion. - Struveina differs from Vandercammenina in possessing regular bifurcating and trifurcating ribs on its flanks, a median rib in the sulcus, a median furrow on the fold, strong dental sockets, and strong brachiophores. Crural plates are never preserved in Struveina, in Vandercammenina indentations above the cardinalia are interpreted as remains of crural plates, in some specimens crural plates are well preserved leaving long and thin slits on the dorsal internal mould.

The dental plates in Struveina are divergent whereas they are oriented almost parallel in Turcispirifer. Struveina has no crural plates which are long and thin in Turcispirifer. The ribs on the flanks are bifurcating and trifurcating in Struveina, in Turcispirifer they never bifurcate on flanks. Struveina lacks a septal pillow and a notothyrial shelf, both characters are developed in Turcispirifer, although in the latter only indicated in some cases.

Ovetensispirifer has a stronger development of secondary shell material in the apical region, strong dental plates, 


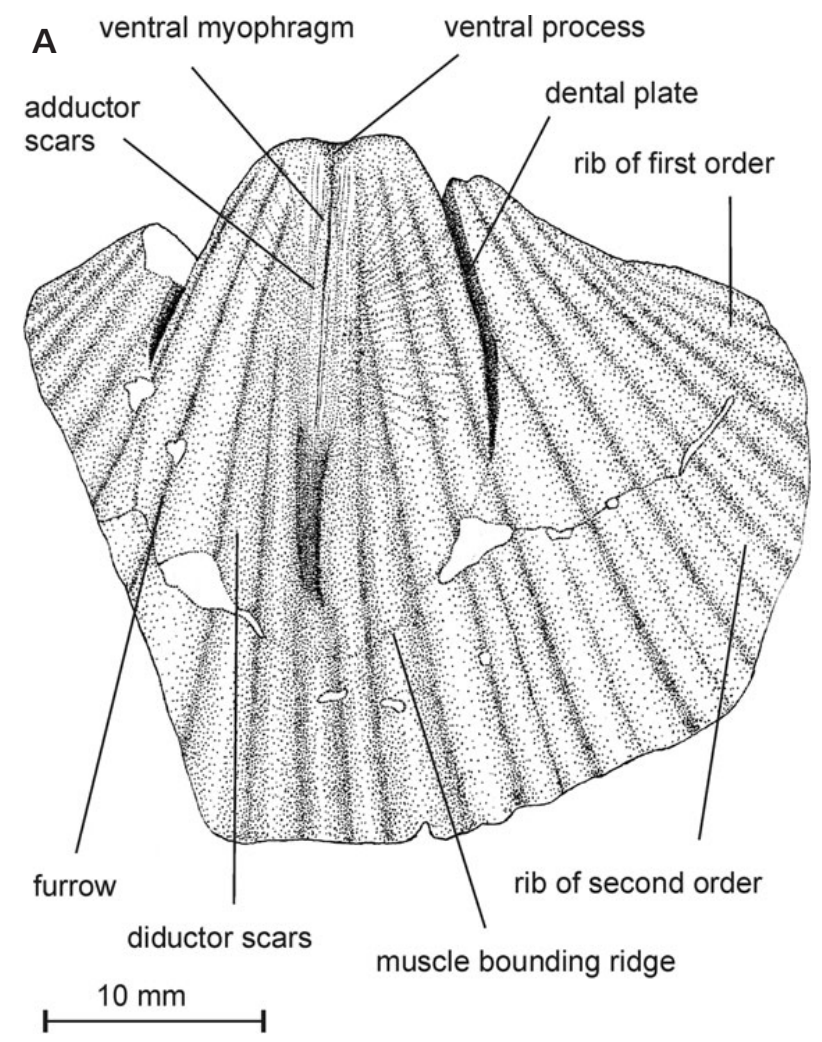

Figure 9. Morphological terms of Struveina daleidensis (Steininger, 1853). • A - MB.B. 2031.1. Ventral internal mould, holotype, plan view. Dental plates, ventral process, myophragm, muscle bounding ridge, and muscle scars are preserved as negative forms. $\bullet B, C-$ SMF 19708. Dorsal internal mould, plan (B) and oblique posterior (C) views. Dental sockets, median process, brachiophores, lateral furrows, and myophragm are preserved as negative forms.

and crural plates. The latter are always lacking in Struveina. Struveina shows bifurcation and trifurcation of ribs in sulcus, on fold, and on flanks whereas Ovetensispirifer shows bifurcation of ribs only in the sulcus and on the fold.

The comparison of Struveina with Fimbrispirifer is described above.

Geographic and stratigraphic occurrence. - Western and Central Europe (Germany, Spain, Belgium, France, England); Lower Siegenian boundary (according to Carls 1987) to Middle Eifelian (middle Lower Devonian to lower Middle Devonian).

\section{Struveina daleidensis (Steininger, 1853)}

Figures 2B, 4B, 5, 9

1853 Spirifer Daleidensis Steininger; Steininger, p. 71.

1878 Spirifer Daleidensis Steininger, 1853. - Kayser, p. 174, pl. 35, figs 4-7.

1889 Spirifer Daleidensis Steininger, 1853. - Kayser, p. 27 , pl. 16, fig. 10 .

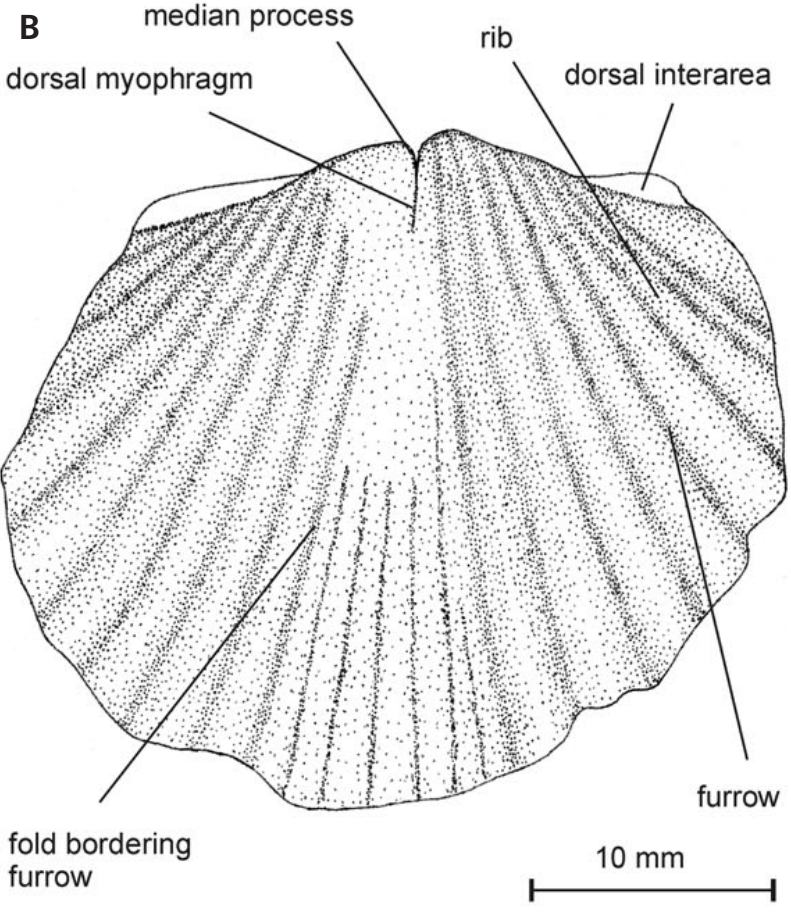

C

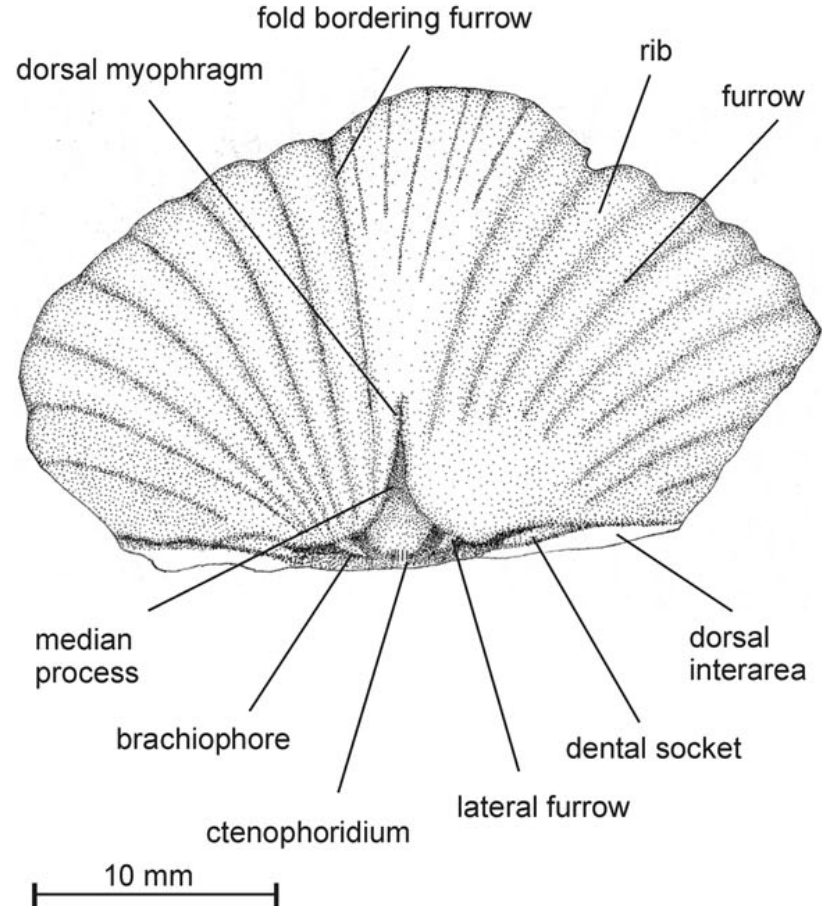

1900 Spirifer Daleidensis Steininger, 1853. - Scupin, pp. 75, 76, pl. 7, fig. 10.

1963 Fimbrispirifer daleidensis (Steininger, 1853). - Vandercammen, pp. 29-35, pl. 2, figs 14-16, pl. 3, figs $1-12$.

Holotype. - Ventral internal mould stored in the Steininger collection as inventory number MB.B. 2031.1. It is illus- 
trated by Kayser (1889, p. 27, pl. 16, fig. 10). Width $36.0 \mathrm{~mm}$ and length $32.6 \mathrm{~mm}$. A plaster cast of the holotype is stored under inventory number SMF 19239.

Type horizon and locality. - Wiltz Formation (Upper Emsian in the classical German sense, upper Lower Devonian); Daleiden, Eifel region (Rheinisches Schiefergebirge, Germany).

Material. - Locality: different sites in the Middle Rhine area, Germany. 1 articulated shell: SMF 19701; 7 internal ventral moulds with corresponding external mould: SMF XVII 906 a, 669, 19700a, b, 19719, 19723, 19724a, b, 66593a, b; 9 internal ventral moulds: MB.B. 2031.1 (holotype), 2031.2, SMF 19686, 19702, 19709a, 19711-19713, 19716, 19722; 1 internal dorsal mould with corresponding external mould: SMF 19686, 19708a, b; 8 internal dorsal moulds: SMF 19703-19706, 19709b, 19714, 66592; 3 external dorsal moulds: SMF 19706, 19717, 19718, 19720.

Diagnosis. - Specimens medium-sized to large with bifurcating and trifurcating ribs on the flanks. Crural plates lacking. Cardinalia strong and coarse. Without septal pillow and deltidium. Ventral muscle field hardly impressed.

Description. - Form and size: shells small to medium-sized with ribs in sulcus and on fold. Outline subsemicircular. Megathyrid without mucronate cardinal extremities. Ventribiconvex in longitudinal section. Exterior of ventral valve: interarea high, apsacline, and curved. Delthyrium open without deltidial lamellae. No deltidium developed. Exterior of dorsal valve: interarea very low, gently anacline to orthocline. Notothyrium open and without chilidial lamellae. Coarse ornamentation: on flanks, ribs are bifurcating and trifurcating on the anterior half of the flanks, unequally in relation to growth stage. Each rib of first order multiplies only once. 8 to 10 bifurcating ribs of first order on each flank on each valve, reaching to a number of 24 ribs of second order at the anterior margin on each flank. Ribs on flanks are of same width at each growth stage and are angular to rounded in cross section. Furrows are angular in cross section. On dorsal valve 1 to 2 ribs fewer than on ventral valve but number of all ribs on flanks varies strongly (Fig. 4B). Sulcus with median furrow. Ribs bifurcating on the internal flank of the sulcus bordering ribs always parallel at same growth stage (Fig. 5). Ribs in sulcus finer than on flanks. Fold moderately high and inconspicuous. First bifurcation on the posterior part of the fold. The following bifurcations are on the external flanks of the ribs of the at the same growth stage. Ribs on fold are weaker than ribs on the flanks. Micro-ornamentation: fimbriate, with single rows of micro-spines on the edge of each growth lamella, similar to the micro-ornamentation of Vandercammenina. Growth lamellae at moderate distance to each other (Fig. 2B). Interior of ventral valve: filling of the umbo extending to posterior over the hinge line. Almost no development of secondary shell material in apical region. Lateral apical cavities are clearly separated by dental plates from the central apical cavity. Fillings of the lateral apical cavities reaching almost as far to posterior over the hinge line as the internal mould of the ventral muscle field. Septal pillow lacking. Ventral process short, leaving a small indention on the internal mould in the posterior end of the muscle field. A short and weakly developed myophragm extends out of the ventral process leaving a fine furrow on the internal mould. Ventral muscle field weakly or not embedded into shell material, always wider than long, with 2 to 3 impressions of ribs on the internal mould. Diductor scars preserved as weak longitudinal striae, anterior margin of the muscle field inconspicuous. Adductor field elongate and weakly impressed into shell material. Muscle bounding ridge often lacking, in some specimens weakly developed leaving an almost inconspicuous furrow on the internal mould. Free portions of dental plates thin and long, sometimes gently wedge-like in gerontic stages. No gonoglyphs preserved. Sulcus deep and without median rib. Sulcus bordering ribs not weakened. 5 to 9 impressions of ribs on internal mould that are bifurcating in anterior half. No impressions of growth lamellae. Interior of dorsal valve: filling of the dorsal umbo does not extend above the cardinalia. Notothyrial shelf lacking. Ctenophoridium situated anterior to the hinge line. Ctenophoridium laterally bordered by a thin furrow on either side preserved as thin and angular ridges on the internal mould. Crural plates and crural bases lacking. Dental sockets coarse and rounded in cross section. Brachiophores not curved over the dental sockets. Median process weak but clearly separating the posterior margin of the adductor scars. Out of the median process extends a weak myophragm that leaves a small furrow on the internal mould. Adductor scars not preserved. Fold moderately elevated and flattened on top. Impressions of ribs like on the internal mould of ventral valve. Growth lamellae are not impressed.

Geographic and stratigraphic distribution. - Western and Central Europe; Siegenian to Emsian in the classical German sense (middle to upper Lower Devonian).

\section{Genus Vandercammenina Boucot, 1975}

Type species. - Spirifer Trigeri de Verneuil, 1850, p. 781.

Emended diagnosis. - Shells medium to large-size. Ribs on flanks simple and angular or rounded in cross section, generally not multiplying by bifurcation or intercalation, in gerontic stage rare bifurcation at the anterior margin; ribs on fold and sulcus of almost same size as on flanks and 
bifurcating or intercalating. Sulcus conspicuous to inconspicuous. Micro-ornamentation fimbriate with narrow micro-spines on the edge of each growth lamellae. Growth lamellae developed at regular distances. Interior of the ventral valve variable. Crural plates free lying or completely embedded into secondary shell material.

[After Carls, unpubl.; from Gourvennec 1989, p. 94; translated and modified from Jansen 2001a, p. 287.]

Species assigned. - Spirifer Trigeri de Verneuil, 1850, Spirifer Bischofi Giebel, 1858, Spirifer Bischofi var. nov. Paucicosta Scupin, 1900, Spirifer Neptunicus Quiring, 1915, Spirifer parcefurcatus Spriestersbach, 1915, Vandercammenina gaugeri Carls, 1986, Vandercammenina sollei Carls, 1986, Vandercammenina aff. bischofi (Giebel, 1858) sensu May, 1988, Vandercammenina hookeri Gourvennec 1989, Vandercammenina nitens Gourvennec 1989, Vandercammenina cf. trigeri (de Verneuil, 1850) sensu Gourvennec 1989, Vandercammenina amfitrite Havlíček, 1994, Vandercammenina sp. A sensu Havlíček, 1994.

Species excluded. - Vandercammenina ovetensium Carls, 1986.

Remarks. - Boucot et al. (1958) reported a new unnamed spiriferid genus from the Lower Devonian of Nova Scotia. Later, Boucot (1960a, b) discussed the relationship of further material to the Rhenish species Vandercammenina bischofi (Giebel, 1858). Part of the material was studied by the present author in the Museum of Comparative Zoology/Harvard University and has been assigned to the new genus Ovetensispirifer, see discussion below.

Discussion. - Vandercammenina differs from Turcispirifer in lacking or having a smaller septal pillow, the lack of a median rib in the sulcus, and of a notothyrial shelf. Vandercammenina in the gerontic stage rarely shows bifurcating ribs on the flanks whereas in Turcispirifer ribs never bifurcate on the flanks.

The species ovetensium is excluded from Vandercammenina and erected as type species of the new genus Ovetensispirifer due to its strong development of secondary shell material in the apical region and the resulting strongly embedded ventral muscle field. Vandercammenina shows little development of secondary shell material in the apical region and a gently embedded ventral muscle field. Ovetensispirifer is strongly dorsibiconvex, the sulcus shows steep flanks, is flat at the base, and its anterior margin is defined by a long sulcus tongue. The sulcus of Vandercammenina is rounded at its base, shows shorter and oblique flanks, the sulcus tongue is short, and its anterior margin rounded. The specimen illustrated by Gourvennec (1989, pl. 7, fig. 12) shows a well developed septal pillow. The ctenophoridium of Ovetensispirifer lies further to the posterior than in Vandercammenina. Ovetensispirifer always shows clearly developed crural plates, which may be absent or only weakly indicated in Vandercammenina.

The comparison of Vandercammenina with Fimbrispirifer and Struveina is described above.

Geographic and stratigraphic occurrence. - Europe, North Africa; Lower Siegenian boundary (according to Carls 1987) to Middle Eifelian (middle Lower Devonian to lower Middle Devonian).

\section{Vandercammenina trigeri (de Verneuil, 1850)}

Figures 2C, 4C, 5, 10

1850 Spirifer Trigeri de Verneuil; de Verneuil, p. 781.

1989 Vandercammenina trigeri (de Verneuil, 1850). - Gourvennec, pp. 94-99, text-figs 48-52, pl. 6, figs 1-27 [non pl. 7, figs 1-5].

2001a V.trigeri (de Verneuil, 1850). - Jansen, pp. 288-291, pl. 34, figs 9-12.

2007 V. trigeri (de Verneuil, 1850). - Jansen et al., tab. 1, fig. 4.19.

Further synonymy see Jansen (2001a, p. 288).

Lectotype. - Articulated shell stored under inventory number D210, illustrated by Gourvennec (1989, pl. 6, figs 1-5). Holotype $47.1 \mathrm{~mm}$ wide and $35.5 \mathrm{~mm}$ long.

Type horizon and locality. - Néhou Formation, Lower Siegenian (middle Lower Devonian); Néhou, abandoned quarry at the Lande du Parc/Manche (Armorican Massif, France).

Material. - Locality and stratum: Assa 1, east of Assa (southern Anti-Atlas Mountains, Morocco). Assa Formation (Rich 1), Lower Siegenian (middle Lower Devonian). 1 ventral internal mould: SMF 59180; 2 dorsal internal moulds: SMF 59181, 59184; 2 ventral shells: SMF 59180, 59183; 2 dorsal shells: SMF 65198, 65398. Locality and stratum: $1 \mathrm{~km}$ S of Modorry, $3.3 \mathrm{~km}$ W of Mezquita (eastern Iberian Chains, Spain); Nogueras Formation, upper d2c beta, upper Lower Siegenian (middle Lower Devonian). 1 articulated shell: SMF 59452 (illustrated by Carls et al. 1993, pl. 36, fig. 60).

Diagnosis. - Shells medium-sized without mucronations. Sulcus with 8 ribs on average, median rib in sulcus lacking, instead with median furrow. About 20 simple ribs on each flank. Sulcus conspicuous. Sulcus bordering ribs not weakened and not included into the sulcus. Ventral interarea apsacline and curved. Hardly any development of secondary shell material in apical region. Free portions of dental 

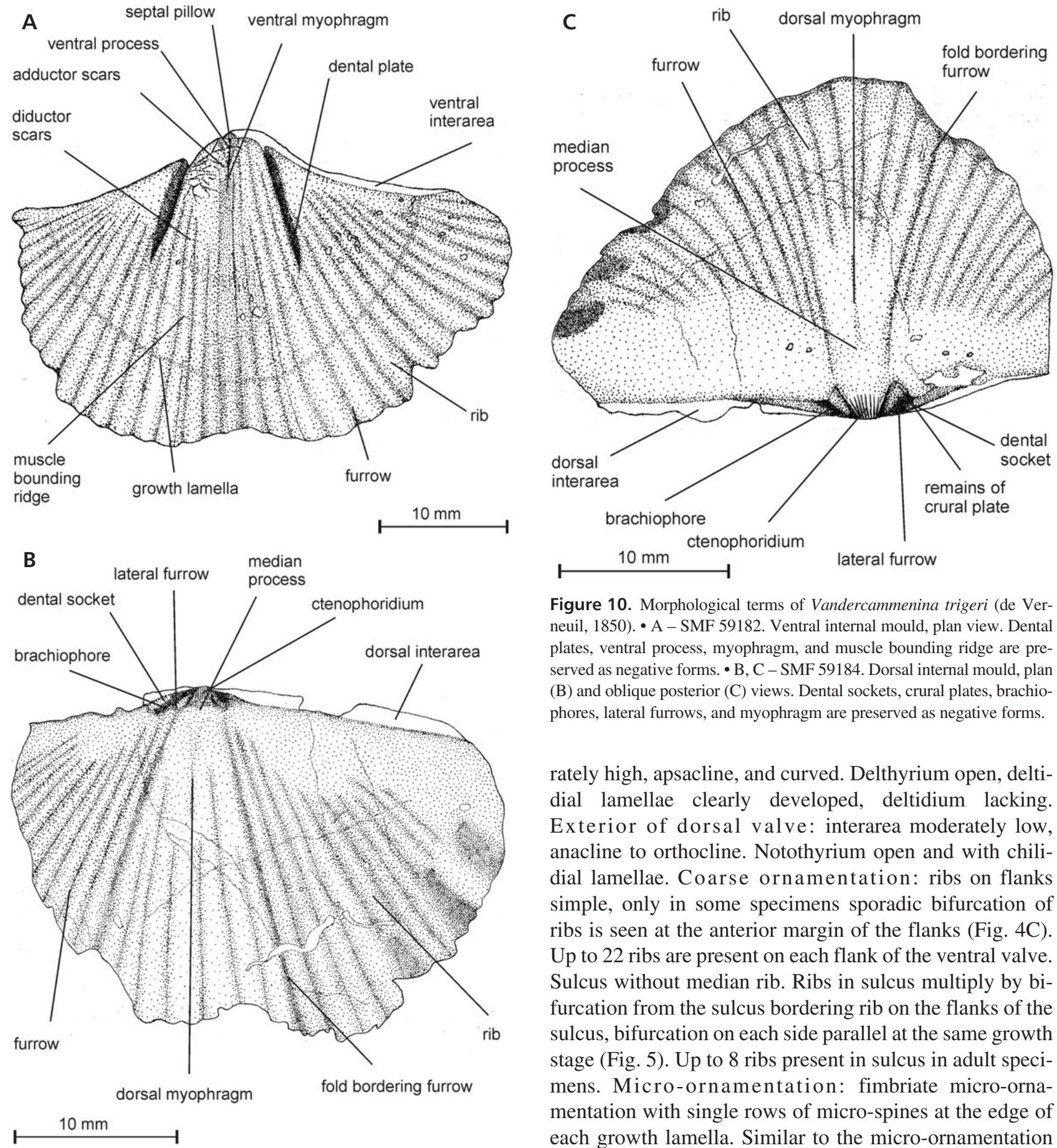

Figure 10. Morphological terms of Vandercammenina trigeri (de Verneuil, 1850). • A - SMF 59182. Ventral internal mould, plan view. Dental plates, ventral process, myophragm, and muscle bounding ridge are preserved as negative forms. $\bullet \mathrm{B}, \mathrm{C}-\mathrm{SMF}$ 59184. Dorsal internal mould, plan (B) and oblique posterior (C) views. Dental sockets, crural plates, brachiophores, lateral furrows, and myophragm are preserved as negative forms.

rately high, apsacline, and curved. Delthyrium open, deltidial lamellae clearly developed, deltidium lacking. Exterior of dorsal valve: interarea moderately low, anacline to orthocline. Notothyrium open and with chilidial lamellae. Coarse ornamentation: ribs on flanks simple, only in some specimens sporadic bifurcation of ribs is seen at the anterior margin of the flanks (Fig. 4C). Up to 22 ribs are present on each flank of the ventral valve. Sulcus without median rib. Ribs in sulcus multiply by bifurcation from the sulcus bordering rib on the flanks of the sulcus, bifurcation on each side parallel at the same growth stage (Fig. 5). Up to 8 ribs present in sulcus in adult specimens. Micro-ornamentation: fimbriate micro-ornamentation with single rows of micro-spines at the edge of each growth lamella. Similar to the micro-ornamentation of Struveina (Fig. 2C). Growth lamellae at a moderate distance from each other. Interior of ventral valve: filling of the umbo extending to posterior over the hinge line. Hardly any development of secondary shell material in apical region. Lateral apical cavities are clearly separated by dental plates from the central apical cavity. Fillings of the lateral apical cavities reaching as far to the posterior as the hinge line on the internal mould of the ventral muscle field. A small septal pillow is developed beneath the posterior end of the ventral muscle field. Ventral process broad, 
leaving a clear indention on the internal mould at the posterior end of the muscle field. A short and weakly developed myophragm develops out of the ventral process leaving a fine furrow through the posterior half of the ventral muscle field on the internal mould. Ventral muscle field only weakly embedded into shell material, always wider than long, and with 2 to 3 impressions of ribs on the internal mould. Diductor scars not preserved. Adductor field elongate and impressed into the internal mould. Muscle bounding ridge often lacking, in some specimens weakly developed leaving an almost inconspicuous furrow on the internal mould. Free portions of dental plates thin and long, situated between the third and fourth rib on the internal mould. Sulcus without impression of median rib. Sulcus bordering ribs not weakened and not included into the sulcus. 4 to 6 impressions of ribs in the sulcus and 13 to 15 impressions of ribs on each flank preserved. No gonoglyphs and no impressions of growth lamellae preserved. Interior of dorsal valve: filling of the dorsal umbo extends gently above the hinge line and overhangs above the cardinalia. Notothyrial shelf lacking. Ctenophoridium situated posterior to the hinge line and bordered by two lateral furrows. Crural plates and crural bases lacking. Dental sockets fine and rounded in cross section. Brachiophores not curved over the dental sockets. Median process almost unrecognisable on the internal mould, neither are the myophragm or the adductor scars. Fold moderately elevated and flattened on top. Impressions of ribs as on the internal mould of ventral valve. Growth lamellae are not impressed.

Geographic and stratigraphic occurrence. - Central, South, and Southwest Europe, North Africa; Siegenian (middle Lower Devonian).

\section{Genus Ovetensispirifer nov.}

Type species. - Vandercammenina ovetensium Carls, 1986 , p. 35.

Derivation of name. - After the type species ovetensium.

Diagnosis. - Medium-sized to large shells, dorsibiconvex in longitudinal section with 1 median and 2 lateral ribs in the sulcus bifurcating in adult stage, and numerous simple ribs on flanks. Sulcus and fold weakly defined; sulcus bounding ribs often included in the sulcus. Strong development of secondary shell material in apical region of both valves. Large septal pillow. Free portions of dental plates wedge-like and short. Crural plates well developed, dental sockets coarse. Notothyrial shelf lacking.

Species assigned. - Vandercammenina ovetensium Carls, 1986, Vandercammenina sp. cf. V. ovetensium Carls, 1986 (sensu Gourvennec, 1989), Ovetensispirifer novascotianus sp. nov.

Discussion. - The genus Ovetensispirifer is erected due to its strong morphological differences from Vandercammenina (see above). The rare bifurcation of ribs, the strong development of secondary shell material in the apical region of both valves, style of ribbing of ribs in sulcus, and the development of crural plates in comparison to Vandercammenina justify the establishment of a new genus.

Turcispirifer differs from Ovetensispirifer in hardly any development of secondary shell material in the apical region of both valves, long and slender dental plates, longer crural plates, and the lack of an embedded ventral muscle field.

The comparison of Ovetensispirifer with Fimbrispirifer, Struveina, and Vandercammenina is described above.

Geographic and stratigraphic distribution. - Armorican Massif, Iberian Chains (southern Europe), ?Istanbul Region (Turkey); Siegenian to Emsian in the classical German sense (middle to upper Lower Devonian).

\section{Ovetensispirifer ovetensium (Carls, 1986)}

Figures 2E, 4D, 5, 11, 12

1969 Fimbrispirifer sp. Carls, p. 311 (Horizon MS 11).

1969 Fimbrispirifer cf. bischofi. - Carls, p. 312 (Horizon MS 12a).

1971 Fimbrispirifer charybdis (Barrande, 1879). - Bultynck \& Soers, p. 9 (Couche 3 = Horizon MS 11).

1980 Vandercammenina sp. X. - Carls \& Heddebaut, p. 219, pl. 32, figs 5-9.

1986 Vandercammenina ovetensium Carls; Carls, pp. 35, 36 , pl. 1, fig. 2.

1987 Vandercammenina ovetensium n. sp. nom. nud. Carls, p. 115.

1989 Vandercammenina ovetensium Carls. - Gourvennec, pp. 101-104, figs 48, 54-56, pl. 7, figs 9-20.

Holotype. - Ventral internal mould with fragmentary corresponding external mould stored under inventory number PZ 102 (figured by Carls 1986, pl. 1, fig. 2). Width $35.7 \mathrm{~mm}$ and length $24.8 \mathrm{~mm}$.

Type horizon and locality. - Fossiliferous marl, bed $1 \mathrm{~m}$ below the middle limestone bed of the Horizon MS 11 (= Ce3 after Bultynck \& Soers 1971) of the Cercadillo Formation (Lower Siegenian sensu Carls 1987); east slope of the Valley Arroyo del Agua (= W side of S Cabeza Gorda), $4.2 \mathrm{~km}$ WSW Riba de Santiuste, $3.2 \mathrm{~km}$ SE Alcolea de las Peñas, topographical mapsheet 434 (Barahona) $1: 50$ 000, Guadalajara Province (Spain). 


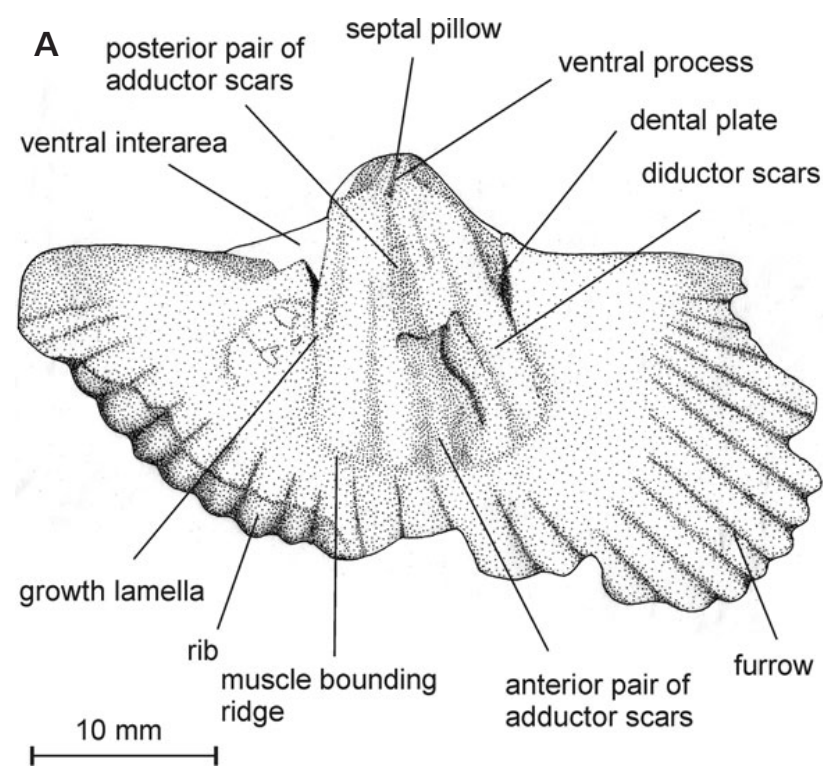

Figure 11. Morphological terms of Ovetensispirifer ovetensium (Carls, 1986). • A - PC 332. Ventral internal mould, plan view. Dental plates, ventral process, septal pillow, and muscle bounding ridge are preserved as negative forms. - B, C - PC 337. Dorsal internal mould, plan (B) and oblique posterior (C) views. Dental sockets, crural plates, and brachiophores are preserved as negative forms.

Material. - Locality and stratum: see type horizon and locality. Four ventral internal moulds with corresponding external mould: PC 333, 344, 340, 341; 4 ventral internal moulds: PC 332, 334, 338, 343; 2 ventral external moulds: PC 331, 336; 1 dorsal internal mould with corresponding external mould: PC 330; 4 dorsal internal moulds: PC 335, $337,339,342$.

Diagnosis. - Ovetensispirifer with 3 ribs in sulcus and 4 ribs on fold, short dental plates, and 2 impressions of ribs on the internal mould of ventral muscle field.

Description. - Form and size: shells medium-sized, megathyrid without mucronations, and subelliptical in outline; equibiconvex to dorsibiconvex in longitudinal section. Exterior of ventral valve: ventral interarea moderately high, apsacline, and curved. Delthyrium open, deltidial lamellae clearly developed, deltidium lacking. Exterior of dorsal valve: dorsal interarea low, anacline, and curved. Notothyrium not recognisable. Coarse ornamentation: ventral and dorsal valves are covered by numerous fine ribs with furrows of same size. Ribs are angular to rounded in cross section and do not bifurcate on flanks (Fig. 4D), furrows are angular in cross section. Lateral ribs in sulcus and on fold bifurcate once in adult stage (Fig. 5). Usually 3 ribs in the sulcus and 4 ribs on fold, in gerontic stage 5 ribs in sulcus and 6 ribs on fold. Growth lamellae are rarely developed at the anterior margin. Micro-ornamentation: fimbriate with single rows
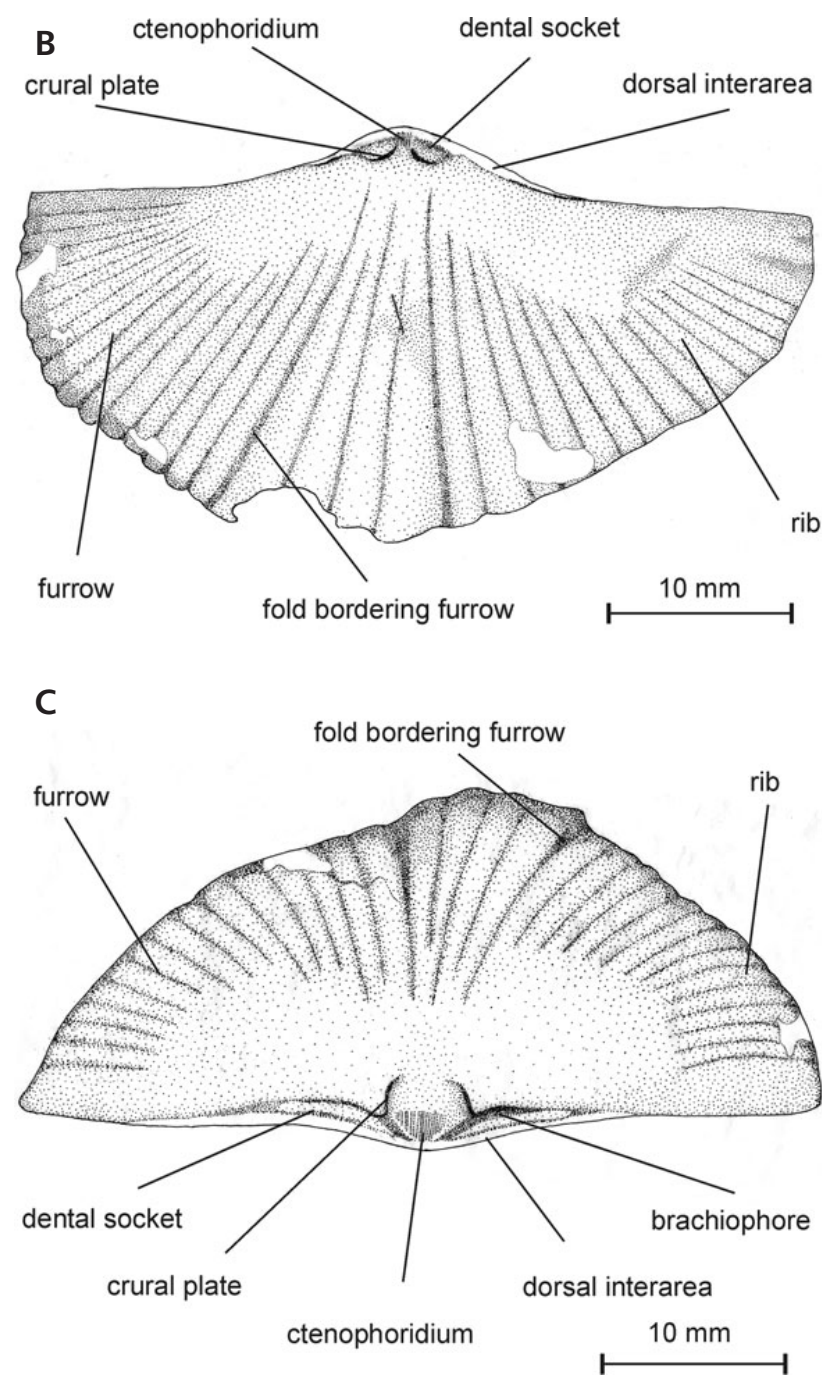

of micro-spines at the edge of each growth lamella. Similar to the micro-ornamentation of Struveina (Fig. 2E). Growth lamellae of moderate distance to each other. Interior of ventral valve: filling of the umbo extending clearly to posterior over the hinge line. Beneath the ventral muscle field a long septal pillow is developed that is medially grooved on the internal mould. Ventral process small leaving only a shallow indention on the internal mould, hardly dividing the posterior end of the ventral muscle field. Out of the ventral process develops a faint myophragm leaving a furrow in the posterior half of the ventral muscle field on the internal mould. Strong development of secondary shell material in the apical region resulting in a strongly embedded ventral muscle field. Fillings of the lateral apical cavities hardly extend posteriorly over the hinge line, but point ventrally in an apical direction. Ventral muscle field with 2 very weak impressions of ribs. Adductor scars elongate and elliptical in outline, posterior and anterior pairs hardly differentiable. Diductor scars preserved as longitudinal striae in the 
Table 3. Comparison of Ovetensispirifer ovetensium, O. cf. ovetensium and O. novascotianus

\begin{tabular}{|c|c|c|c|}
\hline & O. ovetensium & O. cf. ovetensium & O. novascotianus \\
\hline size & medium & medium to large & large \\
\hline outline & $\begin{array}{l}\text { no development of ears } \\
\text { subelliptic }\end{array}$ & $\begin{array}{l}\text { development of ears } \\
\text { subelliptic to subcircular }\end{array}$ & $\begin{array}{l}\text { no development of ears } \\
\text { subelliptic }\end{array}$ \\
\hline curvature & equibiconvex to dorsibiconvex & equibiconvex to strongly dorsibiconvex & equibiconvex to dorsibiconvex \\
\hline ribs in sulcus on internal mould & $3-5$ & not countable & $5-6$ \\
\hline ribs on fold on internal mould & $4-6$ & not countable & $7-8$ \\
\hline $\begin{array}{l}\text { impression of ribs on the internal mould } \\
\text { of the ventral muscle field }\end{array}$ & 2 & not countable & $3-4$ \\
\hline notothyrial shelf & lacking or indicated & lacking & indicated \\
\hline dental plates & short wedge-like & short wedge-like & long thin \\
\hline geographic occurrence & $\begin{array}{l}\text { Iberian Chains (Spain), } \\
\text { Armorican Massif (France) }\end{array}$ & Iberian Chains (Spain) & Nova Scotia (Canada) \\
\hline stratigraphic occurrence & Siegenian & Upper Siegenian & Siegenian to ?Emsian \\
\hline
\end{tabular}

anterior half of the impression of the ventral muscle field. Dental plates short and wedge-like. Out of the dental plates extends a fine muscle bounding ridge leaving a shallow furrow on the internal mould that diminishes in the gerontic stage. A platform is developed at both sides of the ventral muscle field due to the development of secondary shell material. On this platform, gonoglyphs are sometimes preserved as small pointed cones on the internal mould (Fig. 12F, K). Sulcus weakly defined, however, sulcus bordering ribs included into the sulcus. Sulcus rounded in cross section. Bifurcation of ribs is not impressed on the internal mould, neither growth lamellae. Interior of dorsal valve: filling of the umbo extending very little posteriorly over the hinge line. Ctenophoridium broad. Notothyrial shelf lacking or indicated. Dental sockets long, rounded in cross section, and pointing in an apical direction almost to the posterior end of the ctenophoridium. Brachiophores thin and not curved above the dental sockets. Crural bases are not preserved. Crural plates long and thin, reaching to the floor of the shell. Dorsal median process broad and thick leaving deep broad indention on the internal mould. Gonoglyphs in the lateral environment of the dorsal umbo preserved as small tubercles on the internal mould. Impressions of adductor field not preserved. Fold moderately elevated. Fold bordering furrows wider than furrows on fold and on flanks. Impressions of bifurcating ribs on the fold. Impressions of growth lamellae not preserved.

Discussion. - Ovetensispirifer ovetensium is smaller than O. novascotianus, has 2 ribs less in the sulcus, and 2 impressions of ribs on each side of the internal mould of the ventral muscle field whereas $O$. novascotianus has 4 to 5 impressions of ribs on the internal mould of the ventral muscle field. A morphological comparison of taxa of Ovetensispirifer is given in Table 3.
Geographic and stratigraphic occurrence. - Armorican Massif and Iberian Chains (Western Europe); Siegenian (middle Lower Devonian).

\section{Ovetensispirifer cf. ovetensium (Carls, 1986)}

Figures 13, 14

1989 Vandercammenina ovetensium forme 2. - Gourvennec, p. 101, pl. 7, figs 9-20.

non 1989 Vandercammenina sp. cf. ovetensium Carls. - Gourvennec, p. 104, pl. 7, figs 21-23.

2002 huge Vandercammenina. - Carls \& Valenzuela-Ríos, p. 320.

Locality. - Miguel Chico, NW Santa Cruz, Guadarrama (Iberian Chains, Spain).

Material. - 4 ventral internal moulds with corresponding external mould: PC 444, 448-450; 3 ventral internal moulds: PC 442, 445, 447; 1 ventral external mould: PC 443; 1 dorsal internal mould with corresponding external mould: PC 446; 3 dorsal internal moulds: PC 440, 441, 443.

Description. - Form and size: shells medium to largesized, megathyrid without mucronations but sometimes small ears are developed. Equibiconvex to strongly dorsibiconvex in longitudinal section, semielliptic to semicircular in outline. Exterior of ventral valve: interarea high, apsacline to almost catacline, and curved with impressions of transverse growth lamellae. Delthyrium open, deltidial lamellae thin and not fused in the posterior part, deltidium lacking (Fig. 14C, D). Exterior of dorsal valve: interarea low and anacline to almost orthocline. 


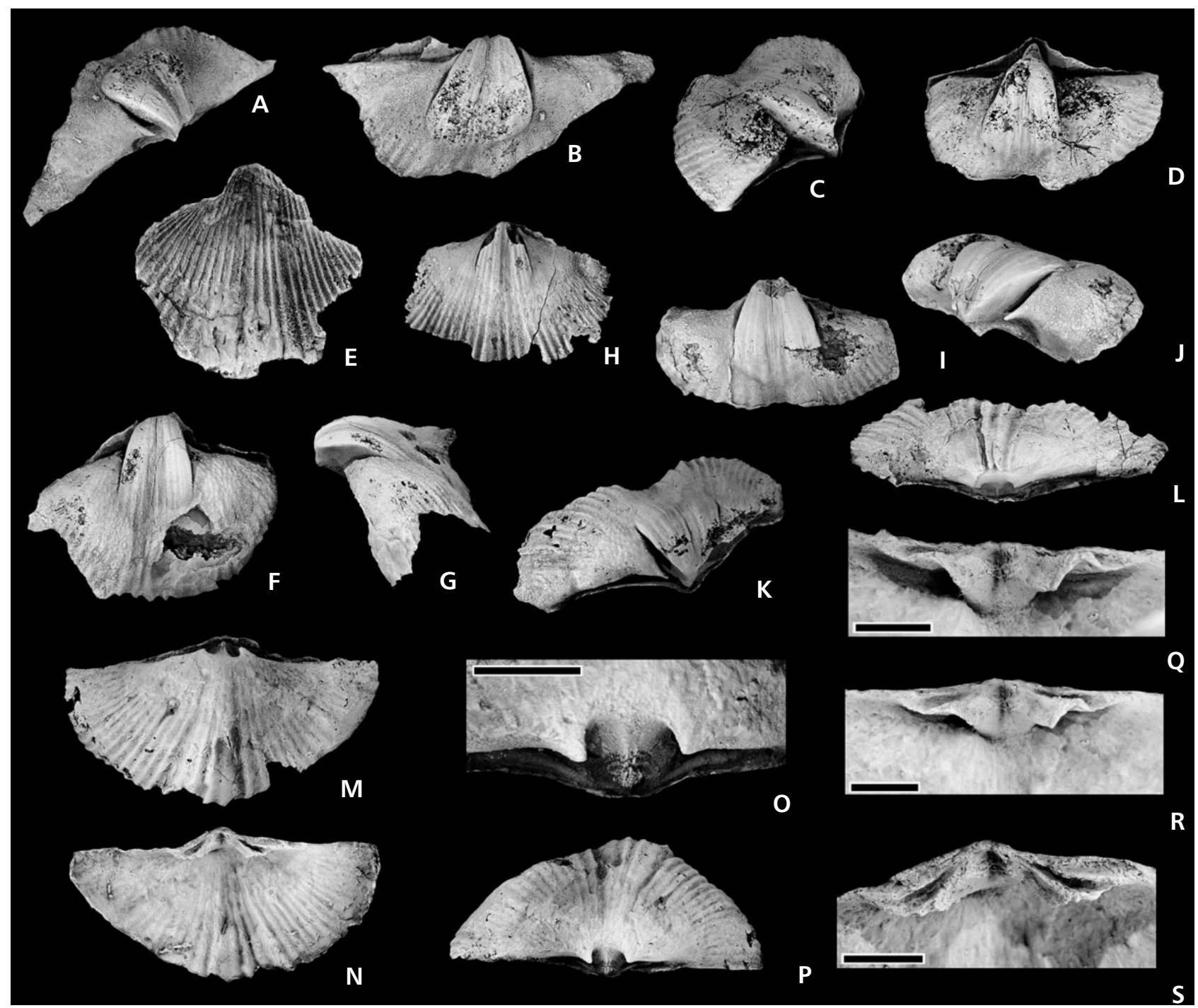

Figure 12. Ovetensispirifer ovetensium (Carls, 1986). Locality: East slope of the Valley Arroyo del Agua (= W side of south Cabeza Gorda), $4.2 \mathrm{~km}$ WSW of Riba de Santiuste, $3.2 \mathrm{~km}$ SE of Alcolea de las Peñas; Topographical mapsheet 434 (Barahona) 1:50 000; Guadalajara Province (Spain). Stratum: Fossiliferous marl bed $1 \mathrm{~m}$ below the middle limestone bed of the Horizon MS 11 (= Ce3 after Bultynck \& Soers 1971) of the Cercadillo Formation (Lower Siegenian after Carls 1987). All figures are original size ( $\times 1.0)$, unless otherwise stated. $\bullet$ A-B - PC 343. Internal ventral mould. Oblique posterolateral (A) and plan (B) views. $\bullet$ C, D - PC 344. Internal ventral mould. Oblique posterolateral (C) and plan (D) views. $\bullet$ E-G - PC 333. Internal ventral mould with corresponding external mould. Plan view (E) on external mould, plan (F) and lateral (G) views on internal mould. $\bullet$ H $-\mathrm{PC} 338$. Internal ventral mould. Plan view. • I-J - PC 341. Internal ventral mould. Plan (I) and oblique posterolateral (J) views; note fillings of lateral apical cavity. $\bullet$ K- PC 340. Internal ventral mould. Posteriolateral view; note gonoglyphs. $\bullet$ L - PC 342. Internal dorsal mould. Oblique posterior view. $\bullet$ M-S - PC 337. Internal dorsal mould and latex cast of it. Plan $(\mathrm{M})$ and oblique posterior $(\mathrm{P})$ views and detail view on cardinalia $(\mathrm{O})$ of internal mould, plan $(\mathrm{N})$, detail anterior (Q), oblique anterior (R), and plan (S) view on cardinalia of latex cast; scale bar $5 \mathrm{~mm}$.

Notothyrium open, chilidial lamellae very thin. Coarse ornamentation: flanks are covered by numerous thin and simple ribs separated by furrows of the same size. Ribs and furrows are rounded to angular in cross section. Sulcus with median rib and fold with median furrow. Ribs on fold and in sulcus are thinner than on the flanks. Bifurcation of ribs in the sulcus occurs once or twice, the first time in the posterior third of the shell, the second time only in the gerontic stage. Bifurcation of ribs on fold corresponds to bifurcation of ribs in sulcus (Fig. 14Q).
Micro-ornamentation: fimbriate as in O. ovetensium. Interior of ventral valve: filling of the ventral umbo extending posteriorly over the hinge line. Strong development of secondary shell material in apical region. A large septal pillow is situated beneath the ventral muscle field from which it is separated by a strong contraction on the internal mould. It is bordered on each side by a subdeltidial furrow that leaves a distinct ridge on the internal mould. Ventral process moderately developed leaving a shallow indention in the posterior part of the ventral mus- 


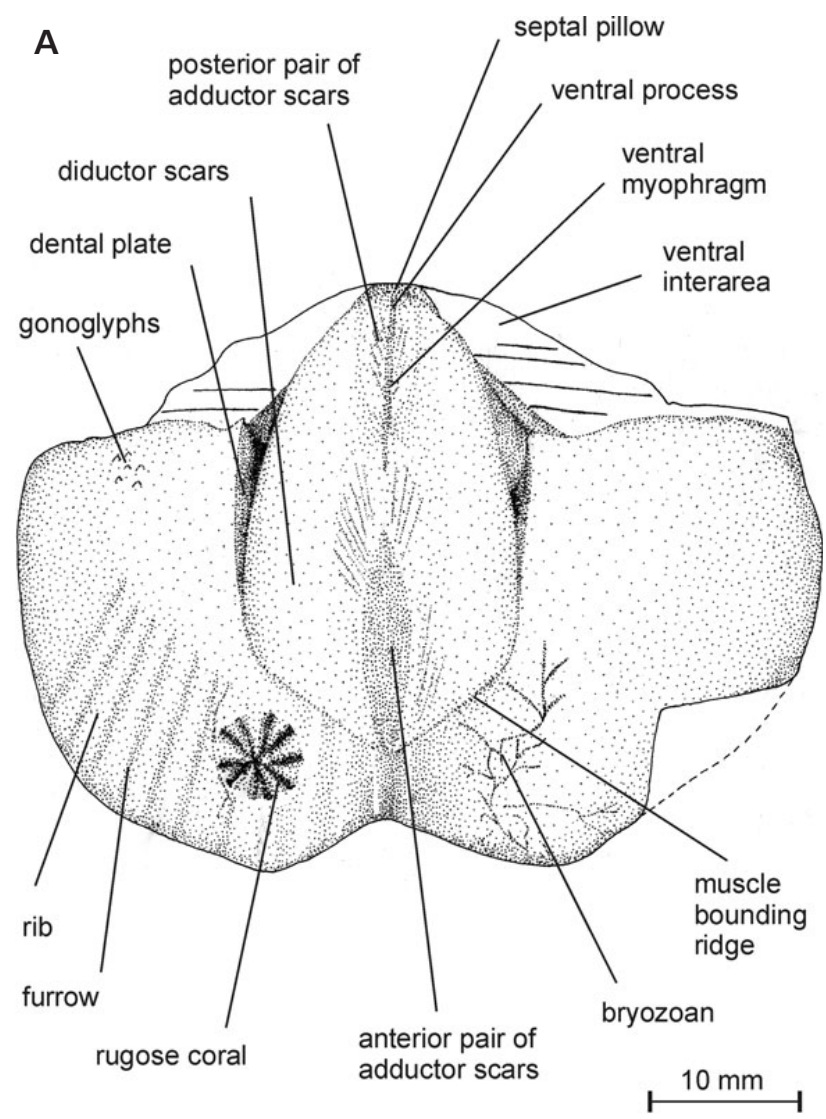

Figure 13. Morphological terms of Ovetensispirifer cf. ovetensium (Carls, 1986). • A - PC 447. Ventral internal mould, plan view. Dental plates, ventral process, septal pillow, myophragm, gonoglyphs, and muscle bounding ridge are preserved as negative forms. $\bullet B, C-$ dorsal internal moulds, plan (B: PC 440) and oblique posterior (C: PC 446) views. Dental sockets, crural plates, lateral furrows, myophragm, and brachiophores are preserved as negative forms.

cle field. Out of the ventral process extends a moderate myophragm leaving a distinct furrow on the internal mould through the posterior half of the muscle field. Impression of the ventral muscle field large and elongate, always longer than wide, and strongly elevated. Diductor scars are preserved as radial striations in the centre and as longitudinal striations in longitudinal direction on the internal mould of the ventral muscle field. Posterior and anterior pairs of adductor scars clearly recognisable, both pairs are thin and elongate. Muscle bounding ridge diminishing in gerontic stage leaving a shallow and moderately broad furrow on the internal mould. Free portions of dental plates short and wedge-like, teeth are very short and knob-like (Fig. 14D). Gonoglyphs are preserved as widely separated and small tubercles on the internal mould (Fig. 14I, J). Sulcus weakly defined, however, impressions of sulcus bounding ribs are the coarsest ones on the ventral internal mould. Impressions of growth lamellae not preserved on the internal mould. Interior of dorsal valve: ctenophoridium bordered by two thin late-
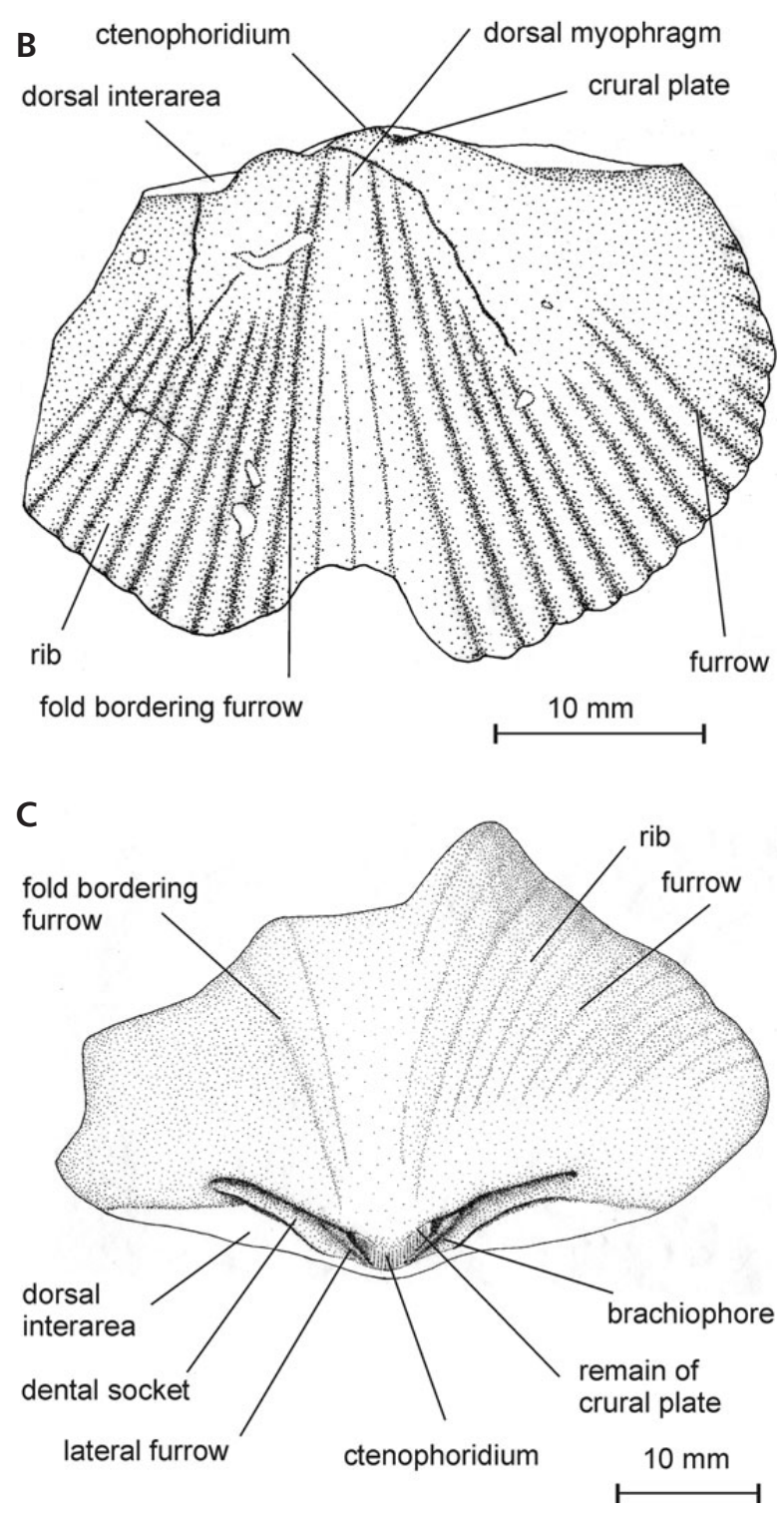

ral furrows that leave thin ridges on the internal mould. Notothyrial shelf lacking. Filling of the dorsal umbo extending above the ctenophoridium. Development of secondary shell material in the apical region of adult specimens. Dental sockets long becoming very thick in adult specimens. Brachiophores thin and not curved over the dental sockets. Crural plates clearly preserved, attached to the valve in juvenile stage and almost completely embedded into secondary shell material in gerontic stage. Median process very weak. Dorsal myophragm short and very fine. Adductor scars not preserved. Fold weakly defined, highly elevated, and angular in cross section. Impressions of ribs diminishing in adult stages and are almost unrecognisable in gerontic specimens on the internal mould.

Remark. - The stratigraphic distribution of $O$. cf. ovetensium is certain for the d3c Top sensu Carls (1996) of the 
Santa Cruz Formation. In the lowermost part of the Mariposas Formation fragments that can be possibly assigned $O$. cf. ovetensium were found, however, the material is not sufficiently preserved to allow a definite determination as $O$. cf. ovetensium. Therefore the range of $O$. cf. ovetensium into the lowermost part of the Emsian in the classical German sense remains speculative.

Discussion. - The main difference between O. ovetensium and $O$. cf. ovetensium is the size of the shells and the stratigraphic distribution. In the material studied, specimens of the type species are relatively smaller and differ from $O$. cf. ovetensium in a more transverse outline and sometimes a notothyrial shelf which is always lacking in $O$. cf. ovetensium. A detailed description of $O$. cf. ovetensium is currently in preparation (P. Carls, pers. comm. 2008). Therefore, open nomenclature is chosen.

Geographic and stratigraphic distribution. - Guadarrama (Spain); d3c Top sensu Carls (1996), Santa Cruz Formation to ?lowermost Mariposas Formation (Upper Siegenian to ?lowermost Emsian in the classical German sense, middle to ?upper Lower Devonian).

\section{Ovetensispirifer novascotianus gen. et sp. nov.}

Figures 15, 16

1958 "Spirifer" n. gen. et n. sp. - Boucot et al., pp. 857, 858, pl. 1, figs 4-9.

1960a "Spirifer" cf. "S." bischofi. - Boucot, pl. 68, fig. 10.

1960b "Spirifer" aff. "S." bischofi. - Boucot, p. 131.

Holotype. - Ventral internal mould stored under inventory number MCZ 191917. Width $50.6 \mathrm{~mm}$ and length $42.5 \mathrm{~mm}$.

Type horizon and locality. - 'Nictaux iron ore beds' [ Oriskany Formation], Pragian, middle Lower Devonian; Nictaux Falls, $c a 40 \mathrm{~km}$ NE of Annapolis, Annapolis Co., Nova Scotia, Canada.

Material. - Locality and stratum: see type horizon and locality. 10 ventral internal moulds: MCZ 191917 (holotype),
191918, 191920, 191921, 191923, 191925, 191928, 191929, 191931; 7 dorsal internal moulds: MCZ 191893, 191915, 191916, 191924, 191930, 191961, NHM B 80230; 2 ventral external moulds: MCZ 191915, 191927; 2 dorsal external moulds: MCZ 191919, 191926. Locality and stratum: Torbrook, ca $45 \mathrm{~km}$ NE of Annapolis, Nova Scotia, Canada; Torbrook Sandstone [ Oriskany Formation], Pragian, middle Lower Devonian. 1 ventral internal mould: MCZ 191896; 1 dorsal internal mould: MCZ 191894, 5 fragments of external moulds: MCZ 191895, 191896.

Diagnosis. - Ovetensispirifer with median rib and 5 to 7 ribs in sulcus, at least 13 ribs per flank, and 3 to 4 impressions of ribs on the internal mould of ventral muscle field. Dental plates thin and long.

Description of holotype.-Form and size: large, megathyrid without mucronations, and subelliptical in outline. Exterior of ventral valve: ventral interarea high, apsacline, and curved. Delthyrium and deltidial lamellae not visible. Interior of ventral valve: broad and long septal pillow beneath the ventral muscle field showing a shallow but broad indention of the ventral process. Ventral muscle field strongly embedded into secondary shell material and with 4 impressions of ribs on the internal mould. Small myophragm in the posterior third of the ventral muscle field. Diductor scars preserved as longitudinal striae at the anterior margin of the muscle field. Dental plates long and thin. Weak muscle bounding ridge developed. Gonoglyphs are preserved as little tubercles on the internal mould anterior and lateral of the muscle field. Impressions of at least 10 ribs on the flanks, impression of median rib in sulcus weakly indicated. Ribs narrow and angular in cross section, furrows broader and round in cross section.

Description of paratypes. - Form and size: shells medium to large-sized, megathyrid without mucronations, and subelliptical in outline; equibiconvex to dorsibiconvex in longitudinal section. Exterior of ventral valve: ventral interarea high, apsacline, and curved. Delthyrium open, deltidial lamellae very thin and not fused in the posterior part of the delthyrium, deltidium lacking. Ex terior of dorsal valve: dorsal interarea moderately high but lower than in the ventral valve, anacline, and curved. No-

Figure 14. Ovetensispirifer cf. ovetensium (Carls, 1986). Locality: Miguel Chico, NW of Santa Cruz, Guadarrama (Iberian Chains, Spain). Stratum: d3c Top (Upper Siegenian, middle Lower Devonian). All figures are at original size $(\times 1.0)$, unless otherwise stated. $\bullet$ A-D - PC 447 . Internal ventral mould and latex cast of it. Plan (A) and oblique lateral (B) views of the mould, plan (C) and oblique lateralposterior views (D) of latex cast; note teeth, dental plates, and delthyrium (D); scale bar $5 \mathrm{~mm}$. $\bullet$ E-H - PC 446. Internal dorsal mould with corresponding external mould. Plan view on external mould (E), posterior $(\mathrm{F})$, oblique posterior $(\mathrm{G})$, and plan $(\mathrm{H})$ views of internal mould; note cardinalia $(\mathrm{G})$; scale bar $5 \mathrm{~mm}$. $\bullet \mathrm{I}-\mathrm{J}-\mathrm{PC} 448$. Internal ventral mould. Plan (I) and anterolateral (J) views; note septal pillow and gonoglyphs. $\bullet \mathrm{K}, \mathrm{L}-\mathrm{PC} 444$. Internal ventral mould. Anterolateral (K) and plan (L) views. - M, N - PC 443. Internal dorsal mould and latex cast of it. Oblique posterior view on internal mould (M) and plan view on latex cast (N). $\bullet \mathrm{O}, \mathrm{P}-\mathrm{PC} 441$. Internal dorsal mould. Plan $(\mathrm{O})$ and oblique posterior $(\mathrm{P})$ views; note crural plates $(\mathrm{P})$. $\bullet \mathrm{Q}-\mathrm{S}-\mathrm{PC} 449$. Internal ventral mould with corresponding external mould. Plan view on external mould $(\mathrm{Q})$, oblique posterolateral $(\mathrm{R})$, and plan $(\mathrm{S})$ views on internal mould. 


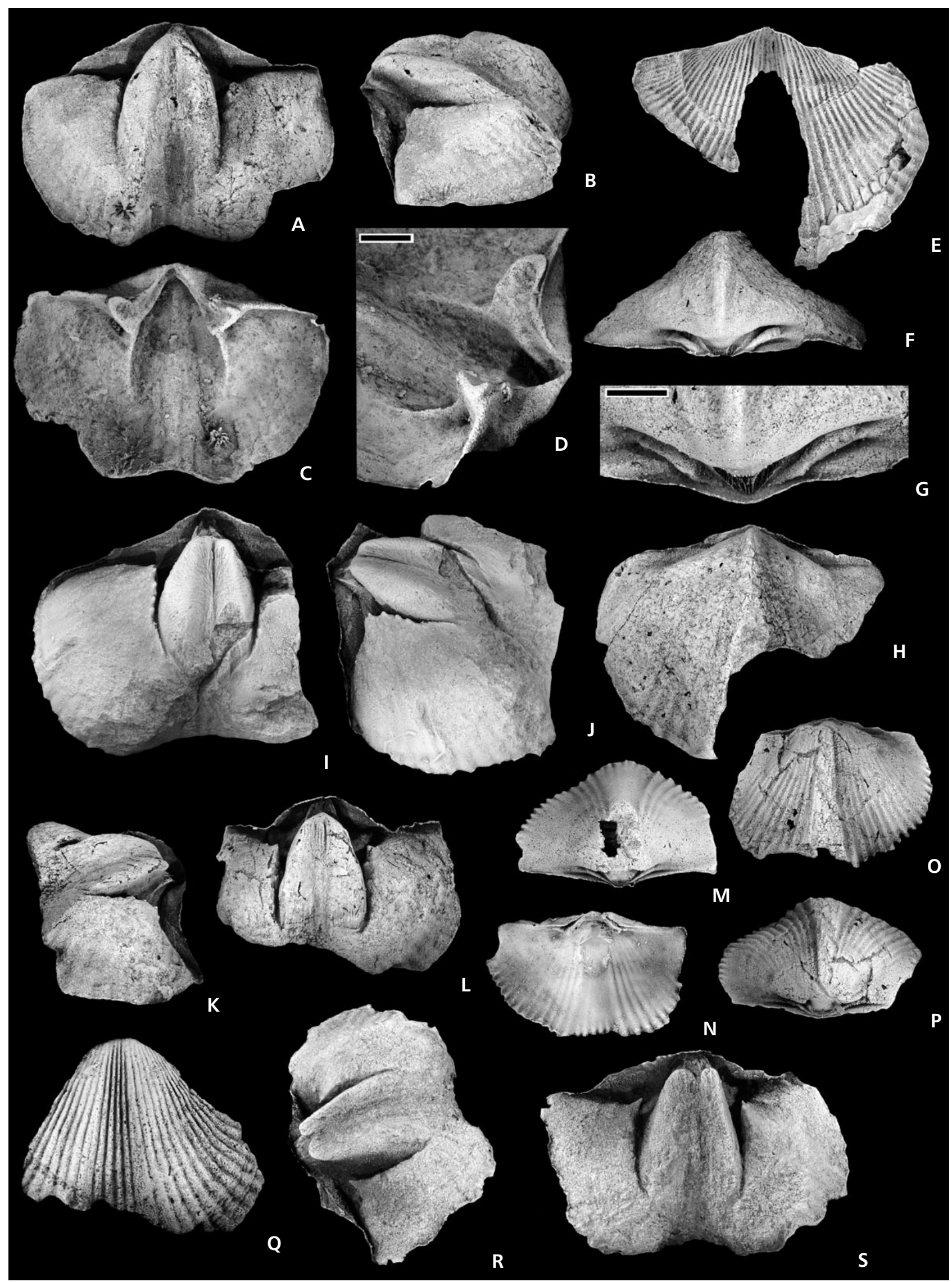




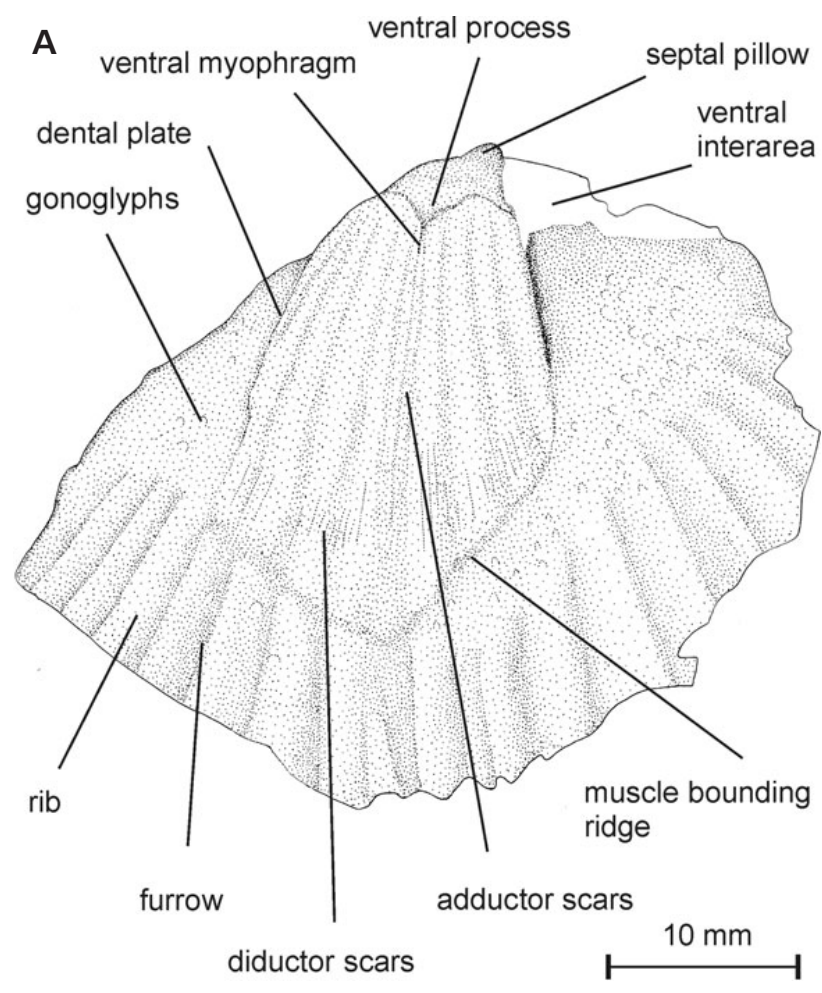

Figure 15. Morphological terms of Ovetensispirifer novascotianus sp. nov. • A - MCZ 191917. Ventral internal mould, plan view. Dental plates, ventral process, septal pillow, ventral myophragm, and muscle bounding ridge are preserved as negative forms. $\bullet B, C-M C Z 191916$. Dorsal internal mould, plan (B) and oblique posterior (C) views. Dental sockets, crural plates, lateral furrows, dorsal myophragm, remain of crural plates, and brachiophores are preserved as negative forms.

tothyrium open. Coarse ornamentation: ventral and dorsal valves are covered by 13 to 18 or more fine ribs with furrows of same size. Ribs are broad, angular to rounded in cross section, and do not bifurcate on flanks (Fig. 16S, T), furrows are narrow and angular in cross section. Sulcus with 3 or 5 , in gerontic stage 7 ribs, and with median rib. Fold with median furrow and with 4 to 6 , in gerontic stage 8 ribs. Bifurcation of ribs in fold and sulcus at first at the very posterior end and later at about half of valve length. Growth lamellae not preserved. Micro-ornamentation: not preserved in the material studied. Interior of ventral valve: filling of the umbo clearly extending posteriorly
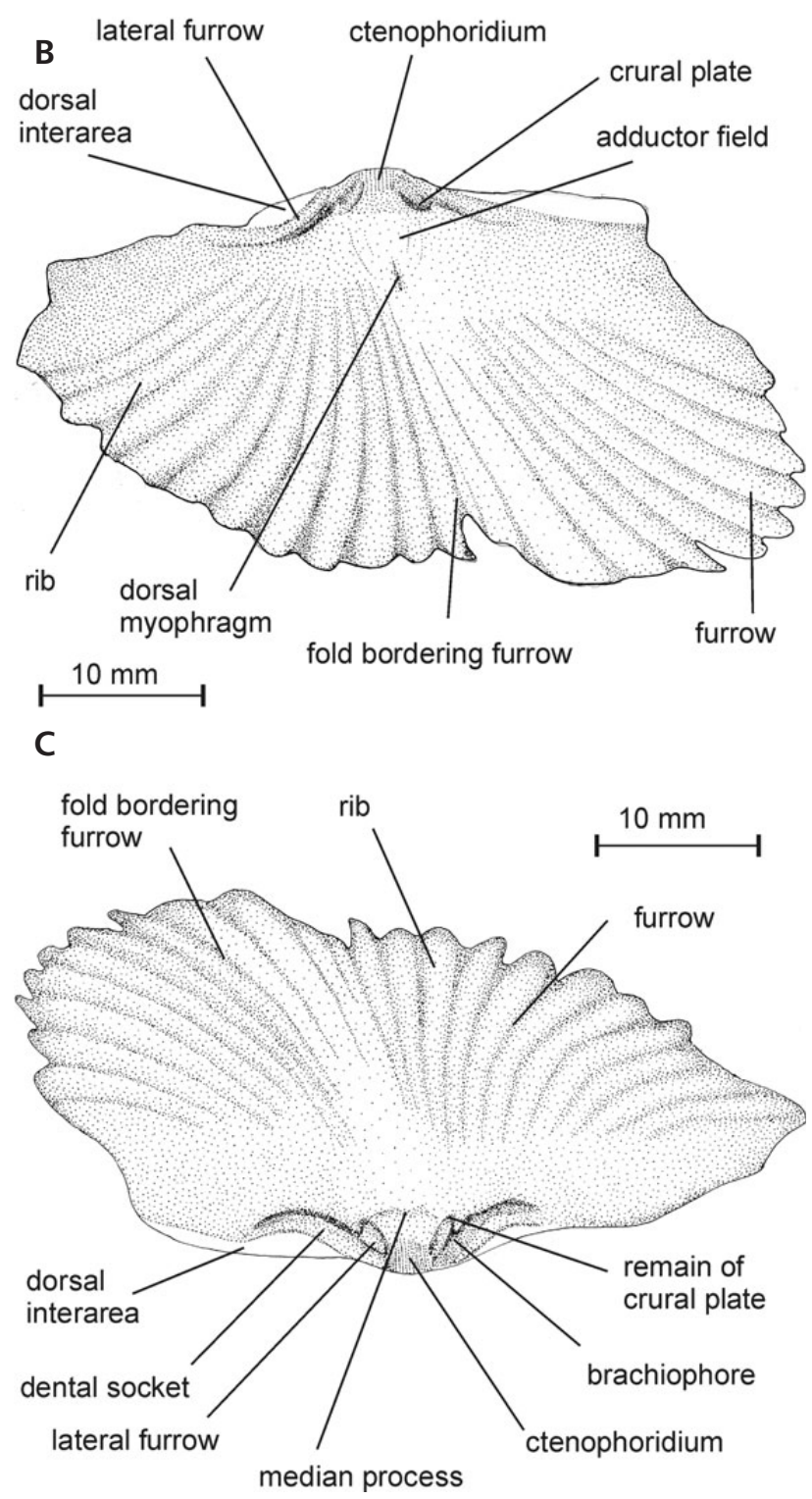

over the hinge line. Beneath the ventral muscle field a thick septal pillow is developed that is medially broadly indented by the ventral process on the internal mould (Fig. 16G). Ventral process small leaving only a shallow indention on the internal mould, strongly dividing the posterior end

Figure 16. Ovetensispirifer novascotianus sp. nov. Locality and stratum (A-T): Nictaux Falls, ca 40 km NE of Annapolis, Annapolis Co., Nova Scotia, Canada; 'Nictaux iron ore beds'. Locality and stratum (U-V): Torbrook, ca $45 \mathrm{~km} \mathrm{NE}$ of Annapolis, Nova Scotia, Canada; Torbrook Sandstone. Both Oriskanian ( Pragian, middle Lower Devonian). All figures are at original size (× 1.0). • A - MCZ 191917. Internal ventral mould. Plan view. $\bullet$ B-D - MCZ 191931. Internal ventral mould. Plan (B), oblique posterior (C), and lateral (D) views. • E - MCZ 191923. Internal ventral mould. Plan view. • F, G - MCZ 191929. Internal ventral mould and latex cast. Posterior view on internal mould (F) and view on apical region of latex cast (G). $\bullet$ H, I - MCZ 191916. Internal dorsal mould. Plan (H) and (I) oblique posterior views. $\bullet \mathrm{J}-\mathrm{L}-\mathrm{MCZ} 191928$. Internal ventral mould. Lateral (J), plan (K) and oblique posterior (L) views. - M-O - MCZ 191961. Internal dorsal mould and latex cast of it. Plan (M) and oblique posterior (N) views on internal mould and plan view on latex cast (O). - P - MCZ 191925. Internal ventral mould. Plan view (P). • Q - MCZ 191920. Internal ventral mould. Plan view (Q). R - MCZ 191921. Internal ventral mould. Plan view (R). $\bullet$ S, T - MCZ 191915. Fragment of internal ventral mould and latex cast. Plan views on latex cast (S) and internal mould (T). - U - MCZ 191896. Internal ventral mould. Plan view (U). V - MCZ 191894. Locality: see Fig. 16U, internal dorsal mould. Plan view (V). 


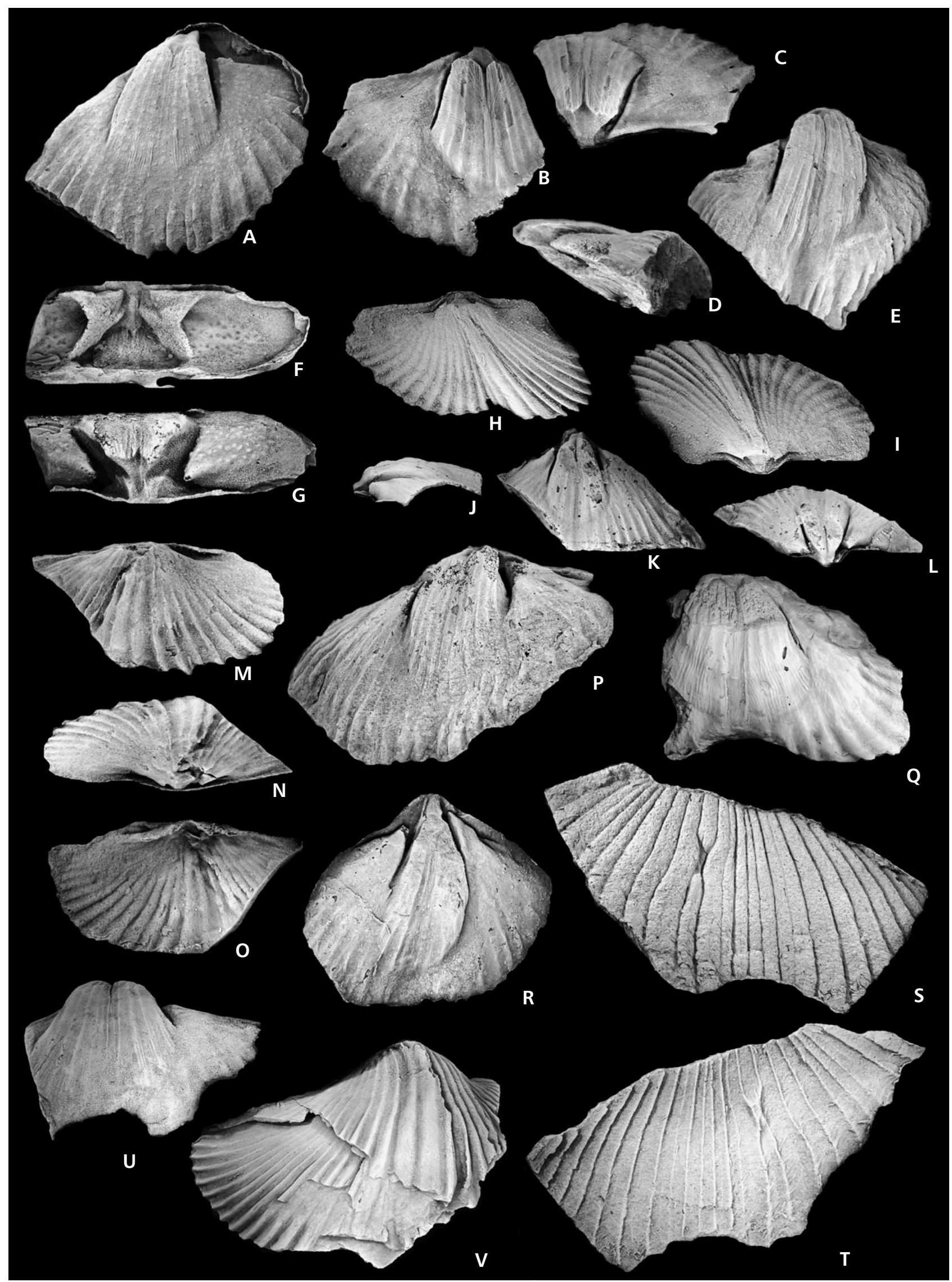


of the ventral muscle field. Out of the ventral process develops a faint myophragm which leaves a furrow in the posterior third of the ventral muscle field on the internal mould. Ventral muscle field strongly embedded due to the development of secondary shell material in the apical region. Internal mould of ventral muscle field strongly elevated and with 4 to 5 impressions of ribs. Adductor scars elongate but only hardly preserved. Diductor scars preserved as longitudinal striae at the very anterior margin of the impression of the ventral muscle field, in one specimen radial striae are preserved in the centre of the impression of the ventral muscle field. Dental plates short to long and thin, teeth not preserved. Out of the dental plates comes a shallow muscle bounding ridge leaving a weak furrow on the internal mould. Gonoglyphs are preserved as small tubercles next to the muscle field on the internal mould (Fig. 16G). Flanks anterior of the ventral muscle field covered by 12 impressions of thin ribs that are rounded to angular in cross section. Furrows broad and shallow, flat on bottom in cross section. Sulcus weakly defined and rounded in cross section with 5 to 7 impressions of ribs including the median rib. Bifurcation of ribs and growth lamellae not impressed on the internal mould. Interior of dorsal valve: filling of the umbo extending posteriorly very little over the hinge line. Ctenophoridium broad and bordered by a pair of weakly developed and faint lateral furrows (Fig. 16N). Notothyrial shelf indicated. Dental sockets long, thin, and rounded in cross section, and pointing in an apical direction almost to the posterior end of the ctenophoridium. Brachiophores broad and not curved above the dental sockets. Crural bases are not preserved. Crural plates long and broad, reaching to the floor of the shell, and not embedded into secondary shell material in adult stages. Dorsal median process broad and short leaving deep shallow indention on the internal mould. Adductor field subelliptical in outline and situated on the fold. Fold moderately to highly elevated and with impressions of 4 ribs that bifurcate in the posterior end. 10 to 12 impressions of ribs per flank. Impressions of ribs start almost at hinge line. Ribs and furrows angular in cross section. Gonoglyphs and impressions of adductor field and of growth lamellae not preserved.

Discussion. - The Nictaux Falls iron ore beds and their fauna have been known for 140 years (e.g., Dawson 1868). Since Dawson's account the brachiopods have been determined by comparison with the European Rhenish fauna but a systematic revision using modern character analysis was still missing. Boucot et al. (1958) examined the iron ore mineralogical properties and proposed a Siegenian age for the fauna. Even though most of the fauna is tectonically deformed and the micro-ornamentation is not preserved owing to metamorphism, most of the specimens show the characteristic features of Ovetensispirifer, e.g., the large, strongly elevated, and impressed ventral muscle field, the crural plates, and the scheme of ribbing in the sulcus, so that a determination even to species level is possible.

Geographic and stratigraphic occurrence. - See type locality and type horizon.

\section{Genus Turcispirifer nov.}

Type species. - Turcispirifer turciae gen. et sp. nov.

Derivation of name. - Genitive form of turcus (= adj., latinization for Turkish).

Diagnosis. - Medium to large-sized specimens with simple ribs on flanks and bifurcating ribs on fold and in sulcus. Crural plates present. Dental plates long, thin, and almost parallel to each other. Hardly any secondary shell material in apical region. Septal pillow present. Cardinalia delicate, notothyrial shelf lacking to weakly indicated in some specimens.

Type horizon and locality. - Kartal Formation (probably Siegenian, middle Lower Devonian); Roumeli Hissar, in the Valley Baltaliman and one of its branches, $c a 9 \mathrm{~km}$ west of Istanbul on the European side of the Bosphorus in the Istanbul Basin (Northwest Turkey).

Species assigned. - Turcispirifer turciae gen. et sp. nov. and ?Turcispirifer sp. A described in this work.

Discussion. - The comparison with Fimbrispirifer, Struveina, Vandercammenina, and Ovetensispirifer is described above.

Geographic and stratigraphic occurrence. - Turkey, ?Morocco; Siegenian to ?Emsian in the classical German sense (middle to upper Lower Devonian).

\section{Turcispirifer turciae gen. et sp. nov.} Figures 2D, 4E, 5, 17, 18

1869 Spirifer trigeri de Verneuil, 1850. - de Verneuil, pp. 41-43, pl. 21, figs 1b, ?3.

1900 Spirifer Trigeri de Verneuil, 1850. - Kayser, pp. 31, 37 , pl. 1, figs 1, 2.

1916 Spirifer trigeri de Verneuil, 1850. - Hüffner, pp. 304, 305, 330, pl. 30, fig. 1.

1932 Spirifer trigeri de Verneuil, 1850. - Paeckelmann \& Sieverts, pp. 66, 67, pl. 3, figs 4, 5 .

Holotype. - Internal mould of dorsal valve, stored under inventory number NYSM 17694. 


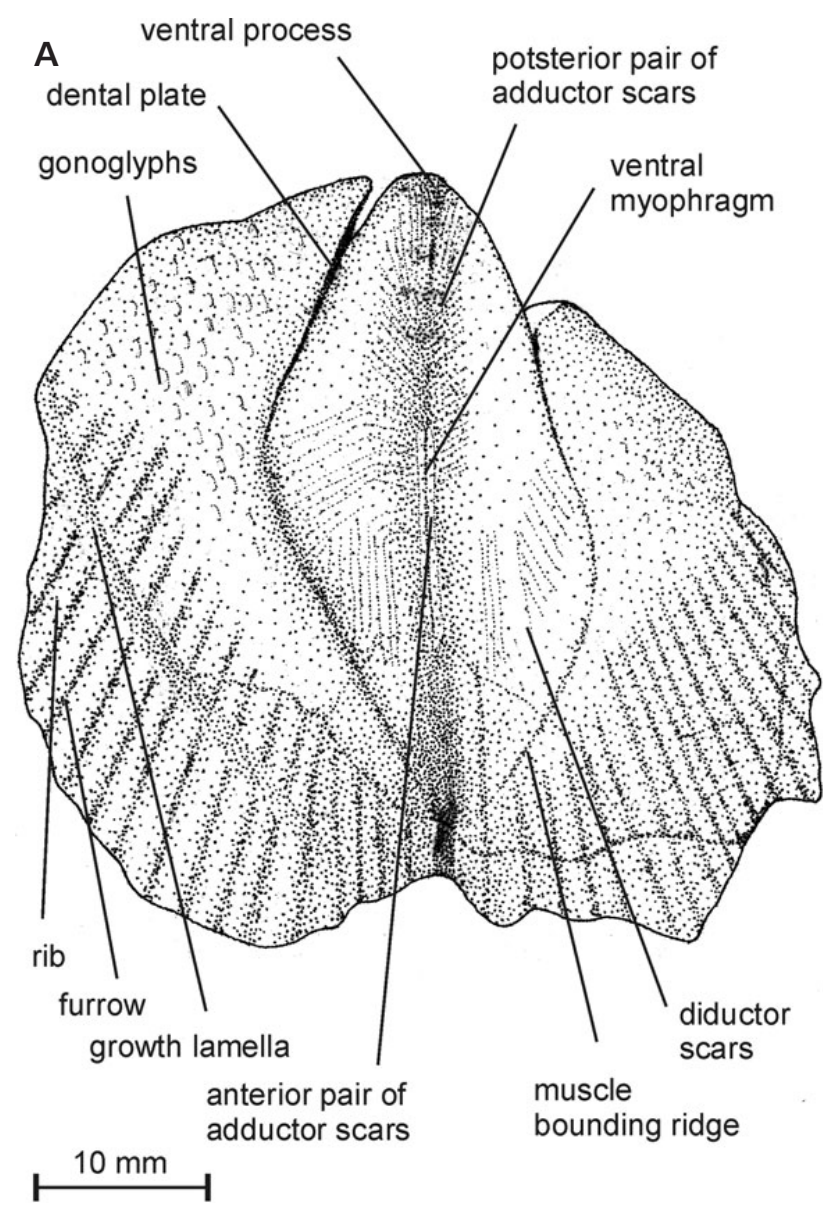

Derivation of name. - Genitive form of Turcia (= latinization for Turkey) where the type locality is situated.

Type horizon and locality. - See genus.

Material. - Locality and stratum: see type locality. 1 internal mould of articulated shell: NYSM 17693; 1 internal dorsal mould: NYSM 17694, holotype; 3 ventral internal moulds: NYSM 17690-17692. Locality and stratum: outcrops along the forest road east of Dallm lake, $3 \mathrm{~km} \mathrm{~S}$ of Korucu village $\mathrm{ca} 8 \mathrm{~km}$ SE of Șile district at the coast of the Black Sea (Northwest Turkey); Kartal Formation, Siegenian to ?Emsian (middle to ?upper Lower Devonian). The Korucuköy Section is described in Gedlk et al. (2005). 1 articulated specimen: DEVEC-TR KO II Ma 9 (1); 2 ventral external shells: SMF 66614, DEVEC-TR KO II Ma 9 (2); 1 internal ventral mould: DEVEC-TR KO II Ma 8 (1); 2 internal dorsal moulds: SMF 66615, DEVEC-TR KO II Ma 8 (2). Locality: between Pendik and Kartal on the Asian side of the Bosporus (NE side of the Sea of Marmara). 2 plaster casts of ventral internal moulds: Mbg. 5130 (original illustrated by Kayser 1900, pl. 1, fig. 1), Mbg. 5131 (mentioned by Kayser 1900, p. 31); 1 ventral external shell: Mbg. 5132. Locality: Pendik on the Asian side of the Bosporus

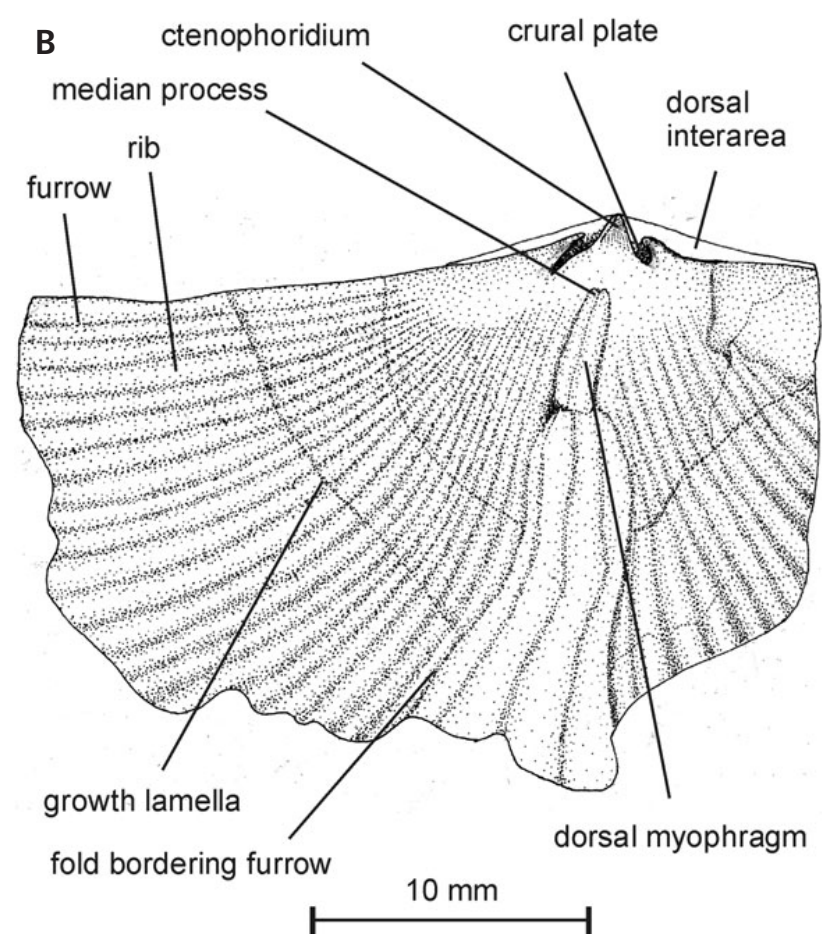

Figure 17. Morphological terms of Turcispirifer turciae gen. nov. et sp. nov. $\bullet$ A - NYSM 17693. Internal mould of articulated specimen, ventral view. Dental plates, ventral process, myophragm, gonoglyphs, and muscle bounding ridge are preserved as negative forms. • B - NYSM 17694 (holotype). Dorsal internal mould, plan view. Dental sockets, crural plates, and myophragm are preserved as negative forms.

(NE side of the Sea of Marmara). 1 ventral external shell: Mbg. 5133. 1 dorsal external shell: Mbg. 5134. Locality: Kartal on the Asian side of the Bosporus (NE side of the Sea of Marmara). 1 ventral external shell: Mbg. 5135. Locality: Büyük Bakkalköy NE of Kartal on the Asian side of the Bosporus (NE side of the Sea of Marmara). 1 ventral external shell: Mbg. 5136.

Remarks. - Specimens studied are from museum collections where the exact horizon from where the material was sampled was not given on the label. Provenance might be either the Kartal or Pendik Formation.

Diagnosis. - See genus which is at present monospecific.

Description of holotype. - Form and size: shells medium to large-sized with bifurcating ribs in sulcus and fold. Brachythyrid without mucronate cardinal extremities, small ears developed. Equibiconvex to gently ventribiconvex in longitudinal section, outline semielliptic. Exterior of dorsal valve: dorsal interarea low and anacline. Notothyrium and chilidial lamellae not recognisable. Interior of dorsal valve: ctenophoridium very thin. Notothyrial shelf lacking. Crural plates long leaving long and 


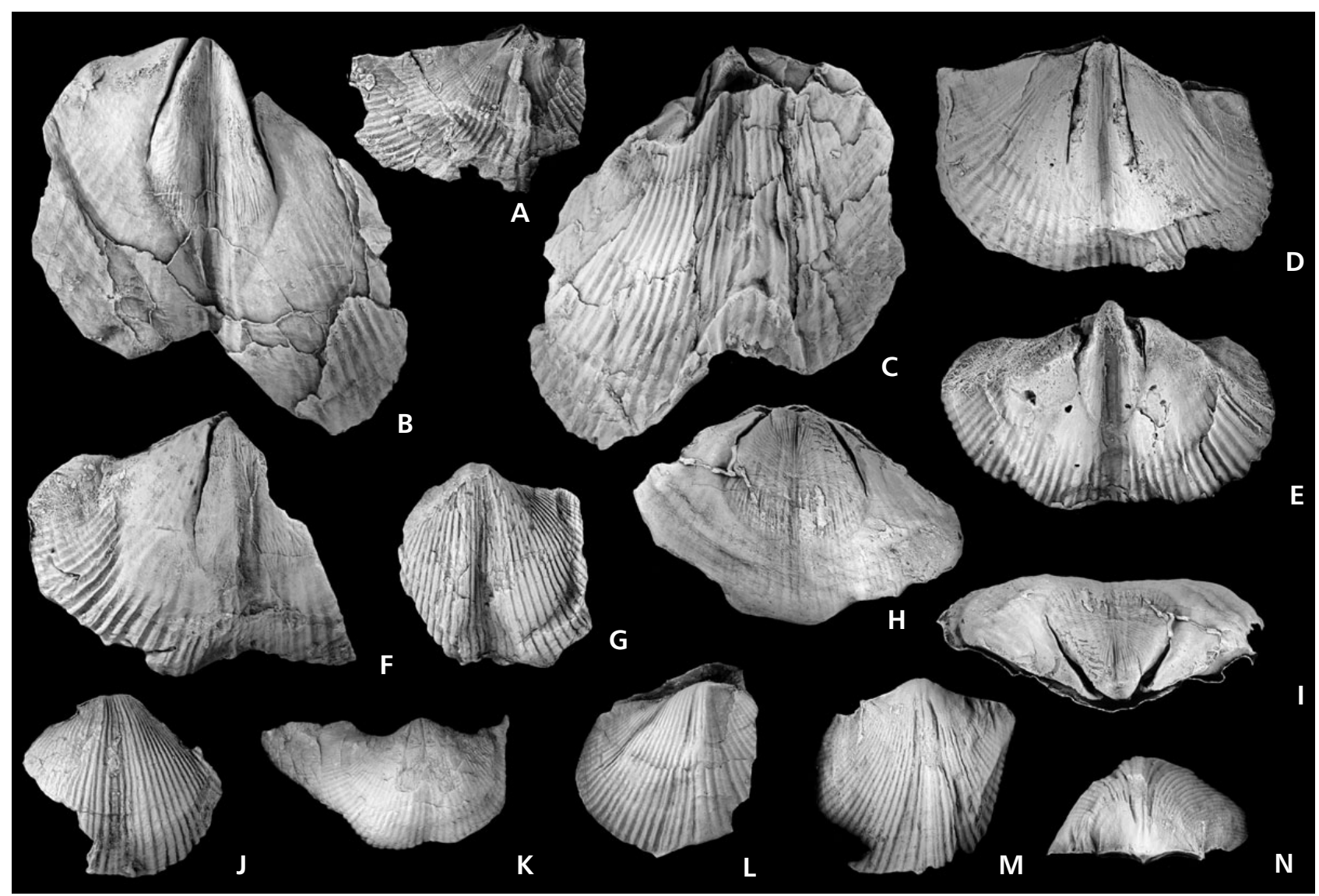

Figure 18. Turcispirifer turciae gen. nov. et sp. nov. Stratum: Kartal Formation, probably Siegenian to ?Emsian in the classical German sense (middle to ?upper Lower Devonian). All figures are at original size $(\times 1.0)$. A - NYSM 17694, holotype. Internal dorsal mould. Locality: Roumeli Hissar, in the Valley Baltaliman and one of its branches, about $9 \mathrm{~km} \mathrm{~W}$ of Istanbul on the European side of the Bosphorus in the Istanbul Basin (Northwest Turkey). Plan view. • B, C - NYSM 17693. Internal mould of articulated specimen. Locality: see Fig. A. Ventral (B) and dorsal (C) views. $\bullet$ D - NYSM 17690. Internal ventral mould. Locality: see Fig. A. Plan view. E - Mbg. 5136. Internal ventral mould. Locality: Büyük Bakkalköy NE of Kartal on the Asian side of the Bosporus (NE side of the Sea of Marmara). Plan view. $\bullet$ F - NYSM 17691. Internal ventral mould. Locality: see Fig. A. Plan view. $\bullet \mathrm{G}-\mathrm{Mbg}$. 5135. External ventral shell. Locality: Kartal on the Asian side of the Bosporus (NE side of the Sea of Marmara). Plan view. $\bullet$ H, I - DEVEC-TR KO II Ma 8 (1). Internal mould of articulated specimen. Locality: Outcrops along the forest road east of Dallm lake, $3 \mathrm{~km} \mathrm{~S}$ of Korucu village at about $8 \mathrm{~km}$ SE of Șile district on the Black Sea coast (NW Turkey). Plan (H) and oblique posterior (I) views. • J - Mbg. 5133. External ventral shell. Locality: Pendik on the Asian side of the Bosporus (NE side of the Sea of Marmara). Plan view. $\bullet$ K - SMF 66614. External ventral shell. Locality: see Fig. 18H. Plan view. $\bullet$ L - Mbg. 5134. External dorsal shell. Locality: see Fig. 18J. Plan view. • M, N - DEVEC-TR KO II Ma 8 (2). Internal dorsal mould. Locality: see Fig. 18H. Plan (H) and oblique posterior (I) views.

fine slits on the internal mould. Dental sockets thin, long, rounded in cross section, and situated almost parallel to the hinge line. Outline of adductor field not recognisable. Dorsal myophragm fine and short. Fold moderately high with median furrow and in the posterior part with bifurcating ribs. Ribs fine and rounded in cross section. Furrows narrower than ribs and rounded to angular in cross section. Impressions of 20 ribs on flanks are countable.

Description of paratypes. - Form and size: shells medium-sized and megathyrid. Ventribiconvex to equibiconvex in longitudinal section, outline semielliptic. Small ears developed. Exterior of ventral valve: ventral interarea high, apsacline to almost catacline, and curved. Delthyrium open with a pair of fine deltidial lamellae that are not combined to form a deltidium. Sulcus inconspicuous. Exterior of dorsal valve: dorsal interarea lower than ventral interarea, anacline to almost orthocline. Notothyrium open, chilidial lamellae very thin. Fold moderately elevated, inconspicuous, only recognisable by bifurcating ribs. Coarse ornamentation: ribs very fine and rounded in cross section. They are separated by smaller furrows that are angular in cross section. Flanks are covered by simple ribs (Fig. 4E). In the sulcus ribs are bifurcating in the posterior part. Sulcus with 10 to 16 ribs at the anterior margin. Median rib lacking (Fig. 5). On the fold all ribs bifurcate once. Micro-ornamentation: fimbriate with single rows of narrow micro-spines situated at the edge of each growth lamella (Fig. 2D). Growth lamellae of moderate distance to each other. Interior of ventral 
valve: filling of the apical cavities extending posteriorly over the hinge line until almost the posterior margin of the internal mould of the ventral muscle field. Hardly any secondary shell material developed in apical region. Septal pillow small, separated by a small contraction on the internal mould of the ventral muscle field. Ventral process small leaving a thin short indention on the internal mould of the ventral muscle field. Ventral muscle field broad, elongated, not impressed into shell material, and extending shortly to posterior over the hinge line. Diductor scars preserved as radial impressions on the internal mould, anteriorly they are striated in a longitudinal direction. Adductor scars elongated and thin, completely surrounded by diductor scars, posterior and anterior pairs are hardly distinguishable. Muscle bounding ridge thin and hardly recognisable leaving a fine furrow on the internal mould. Free portions of dental plates thin and moderately long, reaching to about half of the length of the ventral muscle field. Teeth not preserved. Gonoglyphs preserved as small tubercles with elliptical outline on the internal mould situated in the lateral surrounding area of the ventral muscle field (Fig. 18F). Sulcus of internal mould inconspicuous and without impression of median rib. Impressions of bifurcation of ribs in the sulcus not preserved. Impressions of numerous fine and simple ribs on flanks. Impressions of growth lamellae are impressed at the anterior margin of the internal mould. Interior of dorsal valve: filling of dorsal umbo extends a short distance posteriorly over the hinge line. Ctenophoridium thin and with at least 25 very fine undulating lamellae. Notothyrial shelf lacking. Crural plates clearly developed, leaving long, fine slits on the internal mould. Dental sockets long, triangular in outline, rounded in cross section, and situated almost parallel to the hinge line. Brachiophores thin and not curved above the dental sockets. Adductor scars not impressed. Dorsal myophragm short reaching $1 / 5$ to $1 / 4$ of valve length. Fold moderately high with at least 12 impressions of ribs that are fine and rounded in cross section. Furrows on the internal mould are narrower than ribs and rounded to angular in cross section. At least 26 impressions of ribs on each flank.

Geographic and stratigraphic occurrence. - Northwest Turkey; Kartal and Pendik formations, Siegenian to ?Emsian in the classical German sense (middle to ?upper Lower Devonian).

\section{?Turcispirifer sp. A}

Figures 19, 20

?1964 Fimbrispirifer (?) trigeri (de Verneuil, 1850). - Drot, pp. 63,64 , pl. 5 , fig. $2 \mathrm{a}-\mathrm{c}$.
Locality. - Section Anorhrif I (detailed description in Jansen 2001a and Jansen et al. 2004), N 29 39,44', W $7^{\circ}$ $58,75^{\prime}, S^{\prime}$ of Tata (Morocco).

Material. - 1 internal mould of articulated specimen: SMF 65225; 1 posterior part of a ventral internal mould: SMF 65226.

Description.-Form and size: shells medium-sized, megathyrid without mucronations, ventribiconvex in longitudinal section, and semielliptical in outline. Reconstructed size of internal mould of articulated specimen (SMF 65225): length $29.1 \mathrm{~mm}$ and width $47.1 \mathrm{~mm}$. Exterior of ventral valve: interarea high, apsacline, and curved without impressions of growth lamellae. Delthyrium open, deltidial lamellae and deltidium lacking. Exterior of dorsal valve: interarea low and anacline to almost orthocline. Notothyrium open, chilidial lamellae not preserved. Coarse ornamentation: ribs fine as in Turcispirifer turciae, impressions of bifurcating ribs in sulcus and on fold preserved on the internal moulds, however, external moulds and shell material are lacking in the material. Micro-ornamentation: not preserved in the material studied. Interior of ventral valve: filling of the ventral umbo extending posteriorly over the hinge line. Hardly any development of secondary shell material in apical region. Septal pillow clearly developed posteriorly beneath the ventral muscle field. It leaves a distinct and long ridge on the internal mould and is clearly separated from the muscle field by a strong contraction of the internal mould. Ventral process very small, leaving a hardly recognisable groove on the internal mould. A moderate myophragm develops out of the ventral process through the whole muscle field leaving a distinct furrow on the internal mould. Ventral muscle field elongate, extends posteriorly over the hinge line, and always longer than wide. Diductor scars are preserved as striae in longitudinal direction, adductor scars are not recognisable on the internal mould. Muscle bounding ridge not preserved. Free portions of dental plates long, thin, slightly divergent in anterior direction, and gently curved towards the centre at their anterior margin. Gonoglyphs are not preserved. Sulcus moderately deep and inconspicuous. Impressions of ribs numerous, fine, and rounded in cross section but hardly recognisable on the internal mould. Impressions of ribs in the sulcus of the internal mould are bifurcating, at least 12 to 14 ribs at anterior margin, and are separated by narrow furrows that are angular to rounded in cross section. Interior of dorsal valve: ctenophoridium bordered by strongly developed lateral furrows that are angular in cross section and preserved as distinct rims on the internal mould. Lamellae of ctenophoridium at least 11 and widely spaced. Notothyrial shelf and crural plates lacking. Small depressions above the dental sockets on the internal mould (Fig. 20E) are interpreted as remains of crural plates. Dental sockets thin 


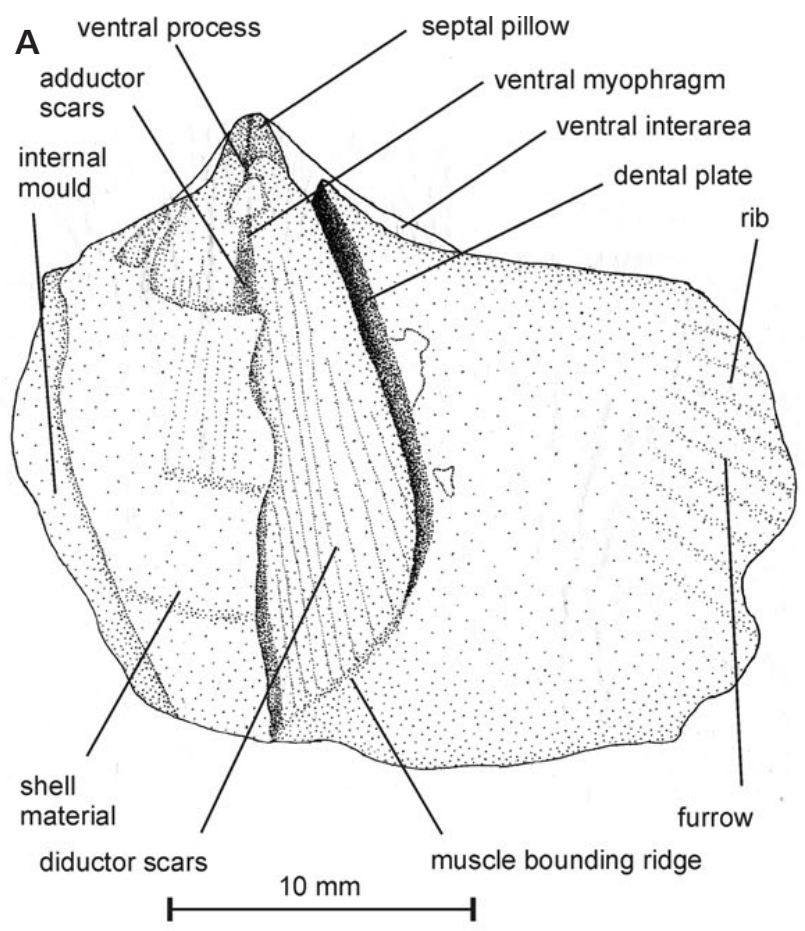

B

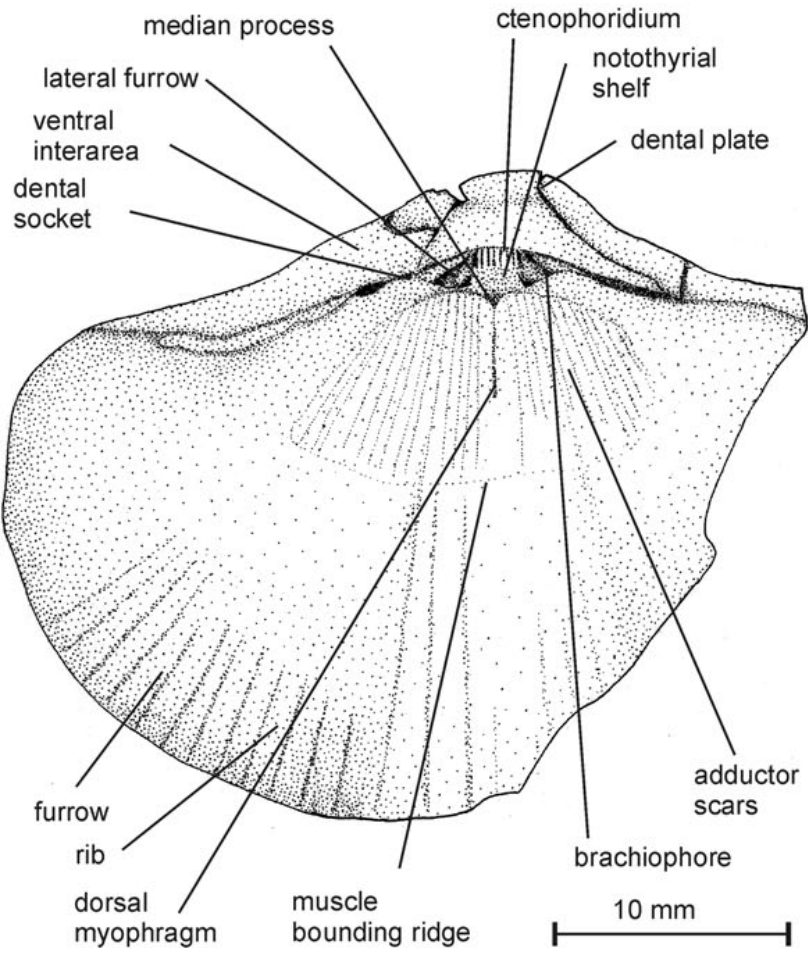

and rounded in cross section. Brachiophores short, thin, and pointing in apical region. Median process very weak. Dorsal myophragm short and very fine. Adductor field slightly embedded into shell material. Anterior and posterior pairs not distinguishable. Adductor scars in posterior region radially striated on the internal mould. Fold incon-

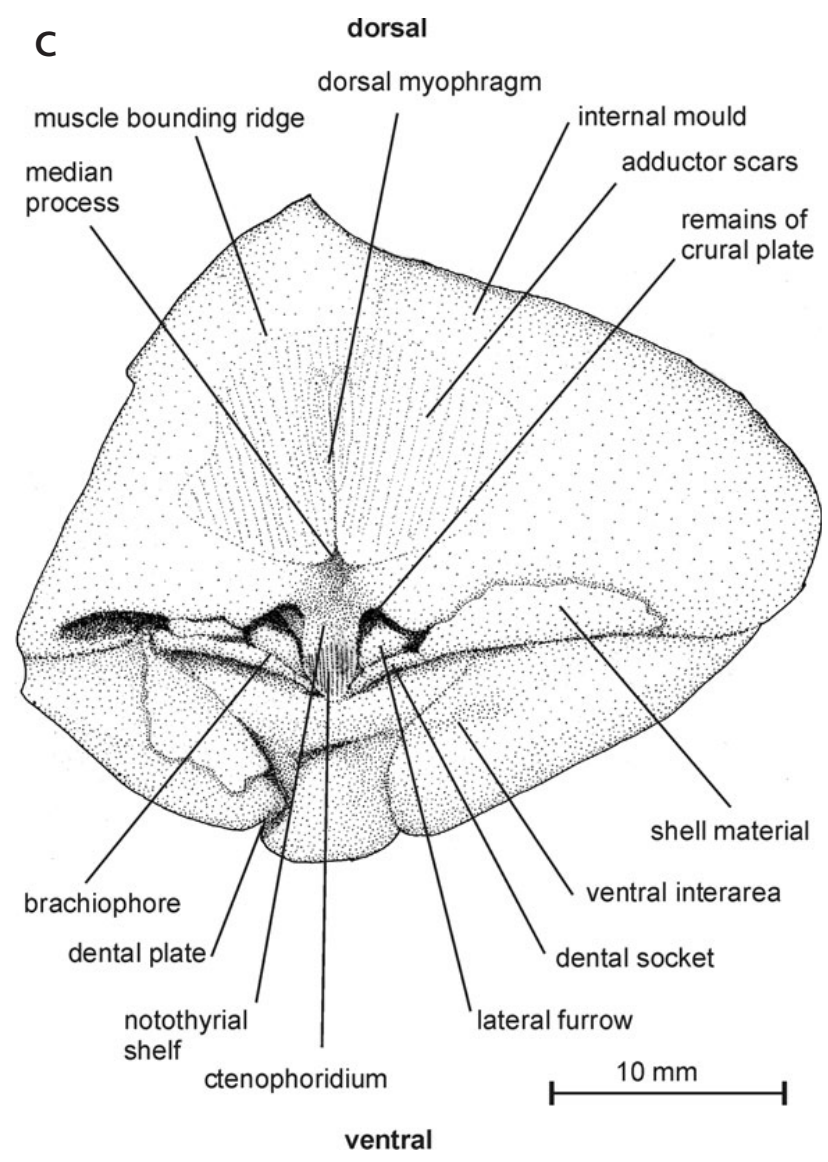

Figure 19. Morphological terms of ?Turcispirifer sp. A A SMF 65225. Ventral internal mould, plan view. Dental plates, ventral process, septal pillow, myophragm, and muscle bounding ridge are preserved as negative forms. • B, C - SMF 65226. Dorsal internal mould, plan (B) and oblique posterior (C) views. Dental sockets, crural plates, lateral furrows, myophragm, and dental plates are preserved as negative forms.

spicuous and moderately elevated. Impressions of fine ribs on flanks and fold in the anterior two thirds of the internal mould that are separated by finer furrows.

Discussion. - The lack of micro-ornamentation and external surface does not allow a definite determination at the genus level, thus open nomenclature is chosen. The internal moulds of ?Turcispirifer sp. A most closely resembles Turcispirifer turciae sp. nov., but the different locality and their probably slightly older stratigraphic assignment argue for another species. Furthermore, the specimens from Morocco have a wider ventral muscle field than $T$. turciae, a shallower sulcus, and weaker impressions of ribs on the internal mould. The crural plates of $T$. turciae are more clearly developed than in ?Turcispirifer sp. A.

Geographic and stratigraphic distribution. - Southern AntiAtlas, Dra Valley, Morocco; Mersâ-Akhsaï Formation (Rich 2), mid- to Upper Siegenian (middle Lower Devonian). 
Family Costispiriferidae Termier \& Termier, 1949 [ex subfamily Costispiriferinae Termier \& Termier, 1949]

Diagnosis. - Shells with numerous fine and low ribs separated by narrow furrows. Ribs on flanks are simple, ribs on fold and sulcus bifurcate or intercalate. Micro-ornamentation capillate without micro-spines.

Remarks. - The Costispiriferinae are lifted to family level (Schemm-Gregory 2008c) because of its style of ribbing and capillate micro-ornamentation. In the last Treatise on Invertebrate Paleontology (Johnson \& Hou 2006, Gourvennec \& Carter 2007), they were regarded as a subfamily of the Acrospiriferidae Termier \& Termier, 1949, which is erroneous as the Acrospiriferidae are characterised by fimbriate micro-ornamentation (Jansen 2000, 2001a, b; Schemm-Gregory 2007, 2008a, b).

Discussion. - Costispiriferidae as well as Elymospiriferidae Johnson \& Hou in Carter et al., 1994 and Multispiriferidae fam. nov. are characterised by capillate micro-ornamentation with and without micro-spines whereas Fimbrispiriferidae have a fimbriate micro-ornamentation. The ribs of Costispiriferidae are lower and rounded in cross section, in Fimbrispiriferidae ribs are rounded to angular in cross section and more elevated.

Costispiriferidae differ from Elymospiriferidae in possessing simple ribs on the flanks whereas ribs of Elymospiriferidae bifurcate and trifurcate on the flanks and are separated by deeper and wider furrows. Costispiriferidae and Elymospiriferidae are both capillate, but Costispiriferidae never show micro-spines at the edge of growth lamellae. Crural plates are well developed in Elymospiriferidae but never in Costispiriferidae. Specimens of Costispiriferidae are in general larger than specimens of Elymospiriferidae. Furthermore, Elymospiriferidae differ from all other families discussed in the development of coarse deltidial lamellae that extend clearly to the posterior.

Multispiriferidae fam. nov. have coarser and 'bundled' ribs with remarkably wider furrows than Costispiriferidae. In Costispiriferidae the ribs are never 'bundled' and also very closely situated to each other. Ribs of Multispiriferidae bifurcate several times during ontogeny whereas ribs of Costispiriferidae bifurcate once. Costispiriferidae are in outline rather subcircular whereas Multispiriferidae are transverse, always wider than long, and subelliptical. In contrast to Costispiriferidae, Multispiriferidae have a septal pillow and a notothyrial shelf but lack a median rib in the sulcus. The cardinalia of Multispiriferidae are situated on an elevated shelf that is more or less in the same plane as the interarea (compare also Boucot 1975, p. 365). The micro-ornamentation of Multispiriferidae is capillate with curved capillae and shows clearly developed

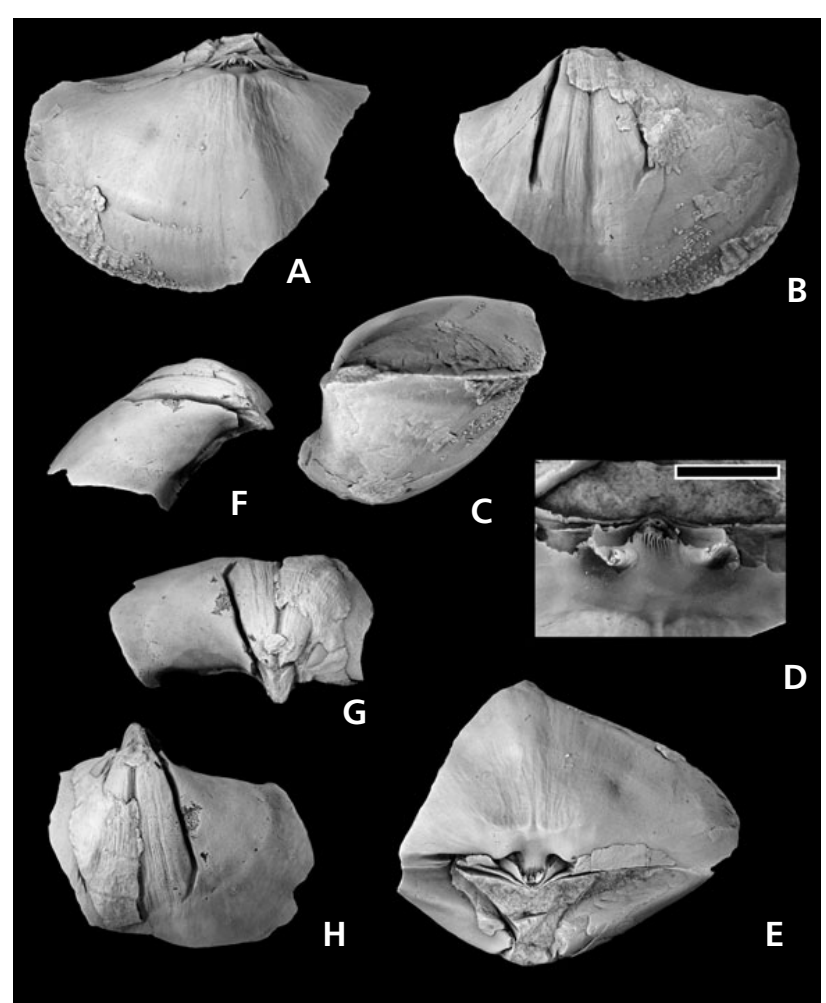

Figure 20. ?Turcispirifer $\mathrm{sp.} \mathrm{A.} \mathrm{Locality} \mathrm{and} \mathrm{stratum:} \mathrm{Section} \mathrm{Anorhrif}$ I, S of Tata (Morocco), N 29 39,44' , W $7^{\circ}$ 58,75' ; Mersâ-Akhsaï Formation (Rich 2), Middle to Upper Siegenian (middle Lower Devonian). All figures are at original size (x 1.0), unless otherwise stated. -A-E - SMF 65225. Internal mould of articulated specimen and latex cast of it. Dorsal (A), ventral (B), lateral (C), and oblique posterior (E) views on the mould, detailed view on apical region (D) on latex cast; scale bar 5 mm. • F-H - SMF 65226. Internal ventral mould. Oblique posterolateral $(\mathrm{F})$, oblique posterior $(\mathrm{G})$, and plan $(\mathrm{H})$ views.

micro-spines at the edge of each growth lamellae developing out of the capillae (Fig. 2F). Micro-spines are always lacking in the capillate micro-ornamentation of Costispiriferidae.

Geographic and stratigraphic distribution. - North America and North Africa; Oriskanian ( Pragian) to Emsian in the classical German sense (middle to upper Lower Devonian).

Subamily Costispiriferinae Termier \& Termier, 1949

Type genus. - Costispirifer Cooper, 1942.

Emended diagnosis. - Ventral interarea high. Delthyrium broad with apical deltidium and strong deltidial lamellae. Dental plates short and divergent. Strong development of secondary shell material in the ventral apical region. Dental sockets coarse. Micro-ornamentation consisting of radially arranged capillae. 
Genera assigned. - At present only the type genus Costispirifer Cooper, 1942.

Genera excluded. - Cumberlandina Boucot, 1975.

Discussion. - Cumberlandina Boucot, 1975 is excluded from Costispiriferinae because of the lack of bifurcating ribs on the flanks as well as on the sulcus and fold, and also by the presence of a stegidium, one of the characteristic morphological features of the Mucrospiriferidae Boucot, 1959 (A.J. Boucot, pers. comm. 2007). Concerning this remarkable difference, I recommend placing Cumberlandina into the family Mucrospiriferidae Boucot, 1959, following the author's intention and in contrast to Johnson (1970) and Johnson \& Hou (2006) in the Treatise on Invertebrate Paleontology.

Geographic and stratigraphic occurrence. - North America and Venezuela; Oriskanian ( Pragian) to ?Emsian (middle to upper Lower Devonian).

\section{Genus Costispirifer Cooper, 1942}

Type species. - Spirifer arenosus var. planicostatus Swartz, 1929, p. 56.

Diagnosis. - Fold and sulcus inconspicuous with bifurcating ribs. Simple ribs on flanks. Without septal pillow, notothyrial shelf, and crural plates.

Species assigned. - Spirifer arenosus Conrad, 1839 (= Spirifera superba Billings, 1874), Spirifer unicus Hall, 1860, Spirifer billingsianus Miller, 1889, Spirifer arenosus var. planicostatus Swartz, 1929, Spirifer dobbinensis Merriam, 1940.

Remarks. - Careful restudy of material from C. arenosus and $C$. superbus shows that these taxa are conspecific. The differences proposed by Billings (1874) in the height of ventral area, depth of the sulcus, respectively, and elevation of fold between these two species are ontogenetic features. The "large undivided rib along the mesial line of both valves" (Billings 1874, p. 46) in C. superbus could not be found, instead the median rib in the sulcus of the material studied was bifurcating.

In the following, $C$. arenosus is described as the characteristic representative of this group. The author of this work studied various extensive collections of the eastern North American Devonian brachiopods and could not find any representative of the type species $C$. planicostatus. As representatives of $C$. arenosus are present in all collections studied yielding material of Oriskanian age from North America, it seems to be more reasonable to describe this taxon with respect to further study on
Costispirifer and for understanding the phylogenetic interpretation of this study.

Discussion. - Costispirifer differs from Multiplicatispirifer in the arrangement of capillae of the micro-ornamentation. In Multiplicatispirifer they are pseudoradially arranged, diverging from the furrows and concavely curved outwards to the top of the ribs whereas in Costispirifer capillae are strictly radially arranged and extend linearly. Ribs in Multiplicatispirifer bifurcate on flanks, fold, and in sulcus in Costispirifer they only bifurcate in sulcus and on fold. Secondary shell material is very thick in the apical region of Costispirifer whereas hardly any is developed in Multiplicatispirifer.

Geographic and stratigraphic occurrence. - See subfamily.

\section{Costispirifer arenosus (Conrad, 1839)}

Figures 2G, 4F, 5, 21, 22

1839 Delthyris arenosus Conrad; Conrad, p. 65.

1860 Spirifer arenosus Conrad, 1839. - Hall, pp. 425-427, pl. 98 , figs $1-8$, pl. 99 , figs $1-10$, pl. 100 , figs $1-8$.

1874 Spirifera superba Billings; Billings, pp. 45, 46, pl. 3, figs $3,3 \mathrm{a}, 3 \mathrm{~b}$.

1908 Spirifer arenosus Conrad, 1839. - Clarke, p. 179, pl. 33, figs $1-10$.

1909 Spirifer arenosus Conrad, 1839. - Clarke, p. 83, pl. 19, figs $1-4$.

1944 Costispirifer arenosus (Conrad, 1839). - Cooper in Shimer \& Shrock, p. 323, pl. 122, figs 27-31.

1984 Costispirifer arenosus (Conrad, 1839). - Benedetto, pp. 120-122, pl. 27, figs 1-13.

Type. - A holotype was not designated in the original description by Conrad (1839). It is strongly desirable to see where all of the original material is stored in order to define a lectotype. I could only visit and study the collection housed in the New York State Museum, Albany, in the American Museum of Natural History, New York City, and in the Peabody Museum of Natural History/Yale University, New Haven but not the collection housed in the Chicago Field Museum, Chicago.

Type horizon. - Oriskanian ( Pragian, middle Lower Devonian).

Material. - Locality: Clarence, New York, USA. 1 ventral internal mould: NYSM 1904. A plaster cast of this mould is stored under inventory number SMF 66616. Locality: Schoharie, New York, USA. 1 ventral internal mould: AMNH FI 34840; 1 dorsal internal mould: AMNH FI 34840. A plaster cast of this mould is stored under in- 


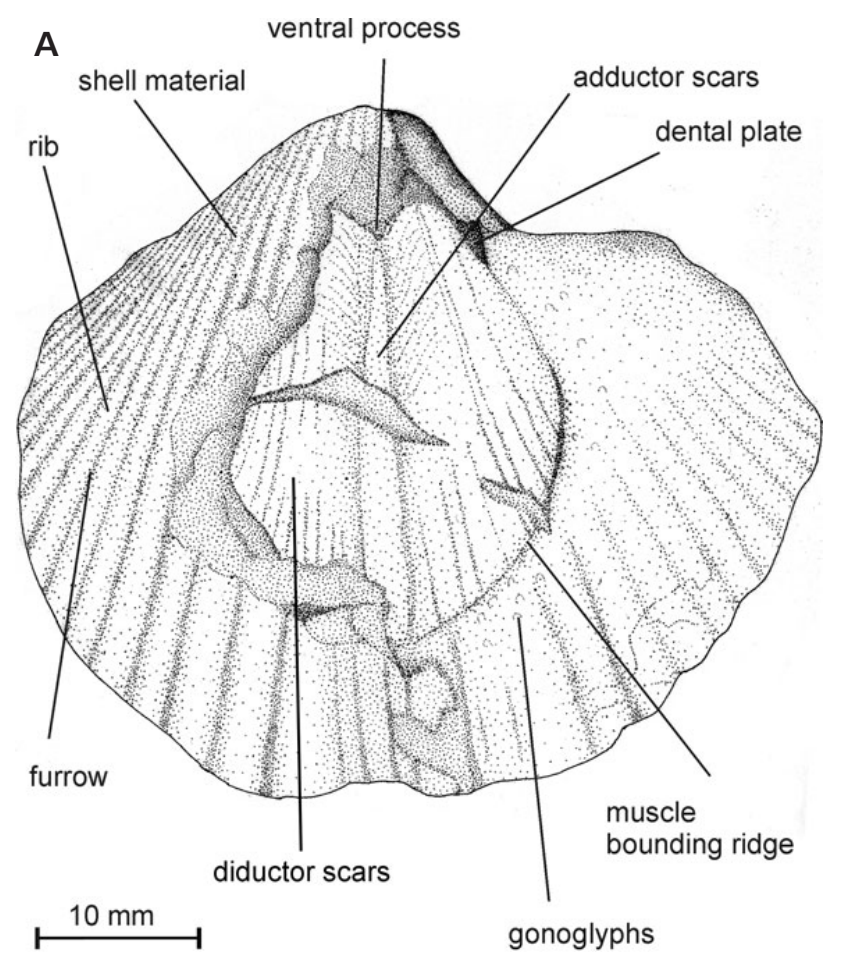

Figure 21. Morphological terms of Costispirifer arenosus (Conrad, 1839). • A - NYSN 1904. Ventral internal mould, plan view. Dental plates, ventral process, and muscle bounding ridge are preserved as negative forms. • B, C - SMF 66617. Plaster cast of dorsal internal mould, plan (B) and oblique posterior (C) views. Dental sockets, lateral furrows, brachiophores, and myophragm are preserved as negative forms.

ventory number SMF 66617; 1 ventral external shell: unnumbered USNM specimen, Boucot Collection. Locality: Murphy's Mountains, Schoharie, New York, USA. 1 ventral internal mould: unnumbered specimen in the Boucot Collection of the USNM. Locality: Knox, New York, USA. 1 ventral shell: SMF 31671; 1 internal mould of articulated shells: AMNH FI 34831. Locality: Cumberland, Allegany County, Maryland, USA. 82 articulated silicified shells: YPM 7147, 402869, 402892-402962, 601202-601206, 601264-601268; 2 ventral silicified valves: YPM 601359, 601360; 3 dorsal silicified valves: AMNH FI 34849, YPM 601361, 601362. Locality: On VA Rt 259, W of Fulks Run village, Rockingham County, Virginia, USA. 1 silicified ventral valve: YPM 221344; 1 silicified dorsal valve: YPM 221345. Locality: Gaspé East county, Grande Grève, S along the wagon road from Grande Grève to about halfway to Cape Gaspé lighthouse, Gaspé Peninsula, Canada. 2 ventral internal moulds: YPM 123919, 221333; 1 dorsal internal mould: YPM 123580 .

Remarks. - Stratum of all specimens Oriskanian ( Pragian, middle Lower Devonian).
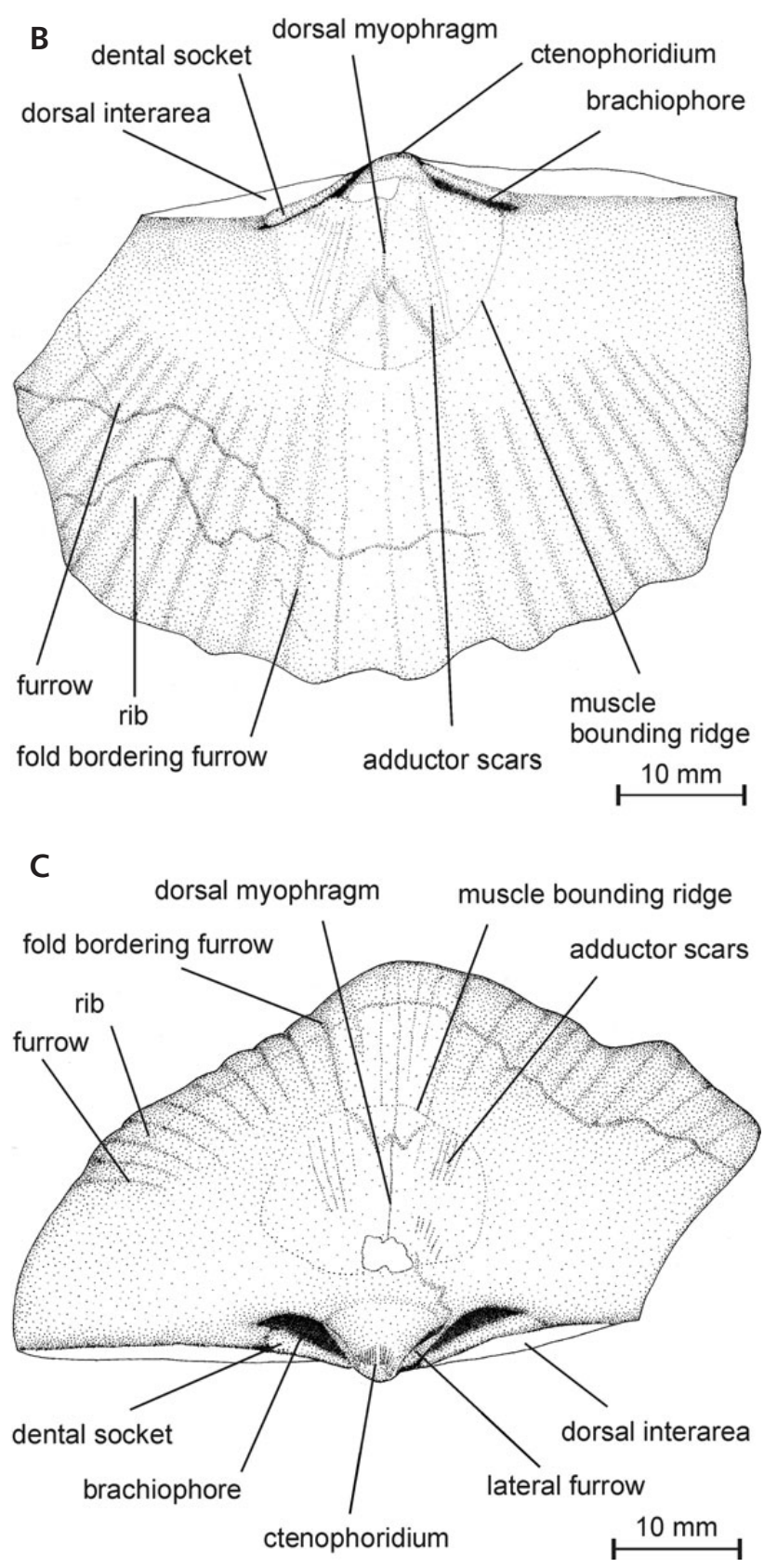

Diagnosis. - Shells megathyrid without mucronations, sometimes small ears developed. Delthyrium large. Ribs in sulcus and on fold bifurcating. Teeth short and knob-like, brachiophores curved over dental sockets.

Description. - Form and size: shells large-sized and megathyrid, without mucronations but often with development of little ears. Ventribiconvex to mostly equibiconvex in longitudinal section, outline semicircular. Exterior of ventral valve: ventral interarea high, apsacline, and straight or curved. Delthyrium broad and open. Deltidial lamellae broad and fused to build a deltidium in the apical part of the delthyrium. Transverse growth lamellae of the 
interarea weakly preserved even on silicified shells. Sulcus shallow, inconspicuous, and rounded to flat in cross section. Exterior of dorsal valve: dorsal interarea low and anacline to almost orthocline. Notothyrium open with thin chilidial lamellae. Fold inconspicuous, faintly elevated, and almost flat on top. Coarse ornamentation: complete shell covered with more than 20 fine ribs that are angular to rounded in cross section. Ribs are separated by finer furrows that are angular in cross section. Ribs on flanks are simple (Fig. 4F). Bifurcation of ribs is visible in the posterior part of sulcus and fold. Ribs in sulcus and on fold somewhat smaller than on flanks. Sulcus with median rib that may bifurcate once. One pair of ribs is intercalated in the posterior part of the sulcus between the lateral ribs of the sulcus and the median rib (Fig. 5). The median rib on the fold bifurcates and a new rib is intercalated. Micro-ornamentation: capillate with capillae radially arranged, rarely interrupted by growth lamellae (Fig. 2G). Growth lamellae well developed at anterior margin. Interior of ventral valve: Filling of the ventral umbo extends posteriorly over the hinge line. At the bottom of the central apical cavity no septal pillow and no deltidial plate are developed. A small ventral process constricts the posterior end of the ventral muscle field leaving a small indentation on the internal mould. Out of the ventral process extends a fine myophragm leaving a fine furrow through the whole impression of the muscle field on the internal mould. The ventral muscle field is broad and pyriform in outline and always longer than wide. It is strongly impressed in the shell due to the strong development of secondary shell material in the apical region. Adductor and diductor scars are clearly differentiable. Adductor scars impressed, long and thin, situated on either side of the myophragm. Posterior and anterior adductor pairs not distinguishable. Diductor scars preserved as longitudinal and radial striations on the impression of the ventral muscle field; longitudinal and straight striations especially present at the anterior margin, radiate striations in the central part of the impression of the ventral muscle field. Long and wedge-like dental plates describing the lateral boundary of the ventral muscle field in younger specimens. In adult and gerontic stages, dental plates very short or even lacking due to the development of secondary shell material; sometimes only preserved as small slits or shallow indentations on the internal moulds. Out of the dental plates originates the muscle bounding ridge that can be very coarse in gerontic stage leaving a deep and broad furrow on the internal mould. Teeth short and knob-like. Lateral of the ventral muscle field a platform is built almost perpendicular to the commissural plane due to the development of secondary shell material. Gonoglyphs are preserved as small, low, and round bumps widely situated on each side in the surrounding area of the ventral muscle field, mainly on the platform, a few occur also just anterior of the platform. Impressions of ribs are anterior of the platform and the ventral muscle field. They are stronger on the flanks than in the sulcus. Interior of dorsal valve: filling of the dorsal umbo extends a little posteriorly over the hinge line. Beneath the dorsal umbo lies the broad ctenophoridium that shows up to 12 lamellae. Notothyrial shelf lacking. Dental sockets cone-shaped and rounded in cross section, situated almost parallel to hinge line, and pointing in an apical direction. Brachiophores thin and curved over the dental sockets. Crural plates lacking, crural bases preserved as free lamellae. Dorsal median process hardly developed. A short and very fine myophragm separates the whole adductor field. Adductor field impressed into shell material with 'mushroom'-like outline and situated on the fold and in the posterior half also lateral of it. Adductor scars preserved as longitudinal striations on the internal mould. A very fine muscle bounding ridge defines the outline of the muscle field leaving a fine furrow on the internal mould. A short, low platform is developed on both sides of the adductor field in gerontic stage. A few gonoglyphs in the form of small, low, and round bumps are

Figure 22. Costispirifer arenosus (Conrad, 1839). All figures are at original size $(\times 1.0)$, unless otherwise stated. • A-E - YPM 601203. Articulated specimen with weathered shell. Locality and stratum: Allegany County, Cumberland/Maryland (USA); Ridgeley Member, Oriskany Sandstone, Oriskanian ( Pragian, middle Lower Devonian). Ventral (A), dorsal (B), posterior (C), anterior (D), and lateral (E) views. • F, G - YPM 402946. Articulated specimen. Locality and stratum: See Fig. 22A-E. Ventral (F) and dorsal (G) views. $\bullet$ H - SMF 66617. Locality and stratum: Schoharie, New York: Oriskany Sandstone, Oriskanian ( Pragian, middle Lower Devonian). Plaster cast of internal dorsal mould, original unnumbered USNM, Boucot collection. Plan view. • I, J - YPM 601360. Ventral shell. I. Plan view (I) on ventral interior and detailed view (J) on delthyrium, deltidial lamellae, and deltidium (x 3.0). Scale bar represents $5 \mathrm{~mm}$. $\bullet \mathrm{K}-\mathrm{M}-\mathrm{YPM}$ 601362. Dorsal shell. Locality and stratum: See Fig. 22A-E. Plan view on dorsal exterior (K) and interior (L), detailed view (M) on cardinalia (x 3.0). Scale bar represents 5 mm. $\bullet$ N, O - YPM 402935. Articulated specimen with weathered shell. Locality and stratum: See Fig. 22A-E. Ventral (N) and dorsal (O) views. • P, Q - YPM 402894. Articulated specimen with weathered shell. Locality and stratum: See Fig. 22A-E. Ventral (P) and dorsal (Q) views. • R - SMF 66616. Locality and stratum: Clarence, New York; Oriskanian ( Pragian, middle Lower Devonian). Plaster cast of ventral valve with weathered shell, original NYSM 1904. Plan view. $\bullet$ S - YPM 601359.Ventral shell. Locality and stratum: See Fig. 22A-E. Plan view on ventral interior. • T - YPM 221342. Locality and stratum: Beach shingle, Percé Rock, Percé, Gaspé East County, Québec (Canada); Oriskanian ( Pragian, middle Lower Devonian). External dorsal valve. Plan view. - U - YPM 221339: Locality and stratum: See Fig. T. External ventral valve. Plan view. • V - YPM 221310. Locality and stratum: small quarry beside road a few hundred metres W of house of Joseph Gave, about 1 km NW of Grande Grève, Gaspé East County, Québec (Canada); Grande Grève Limestone, Oriskanian ( Pragian, middle Lower Devonian). External dorsal valve. Plan view. [Remark: T-V - all specimens belong to the rejected species C. superbus (Billings, 1874).] 


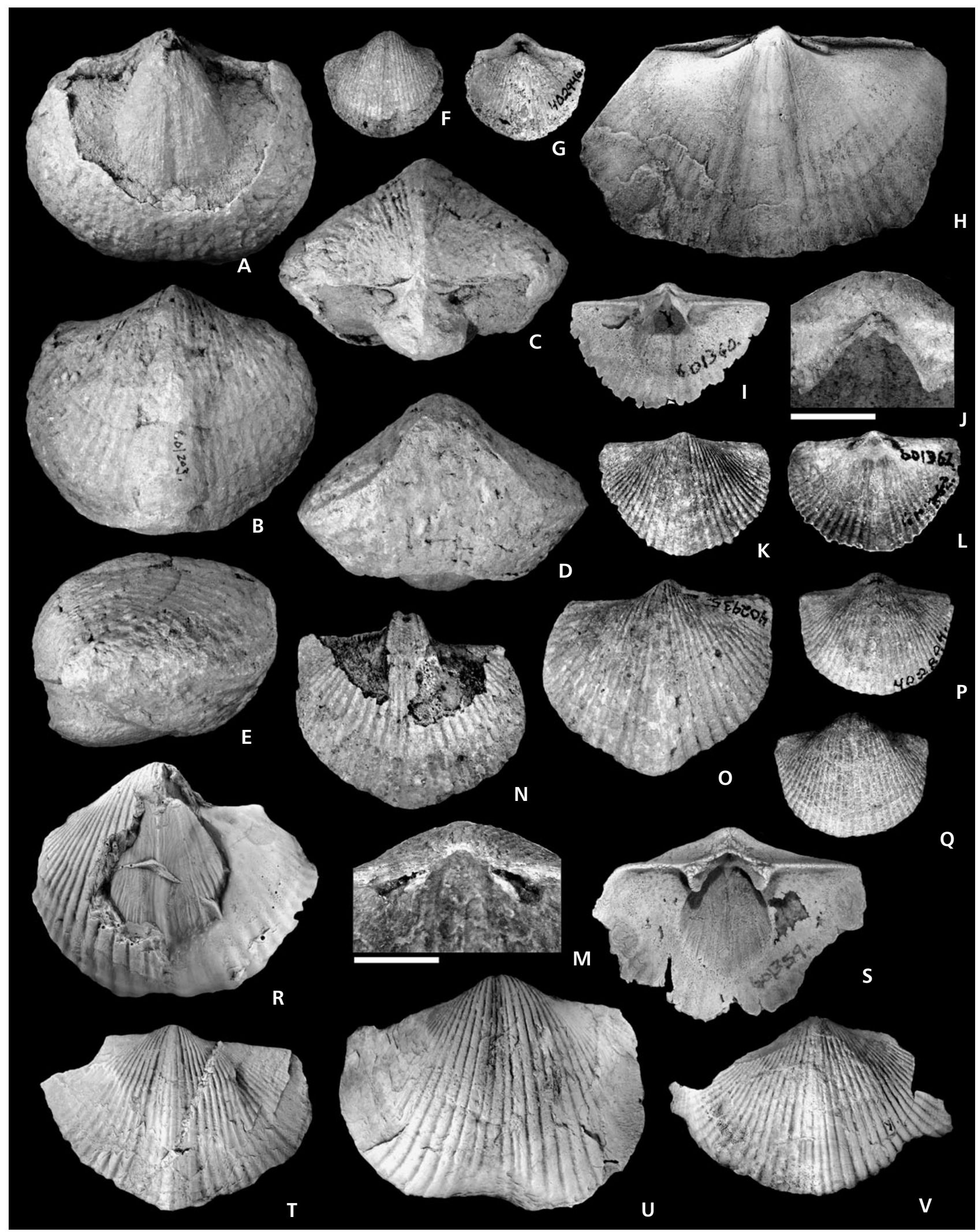


situated with wide interspaces on this platform above the dental sockets and brachiophores. Fold inconspicuous and hardly elevated compared to the flanks. Top of fold broadly rounded to almost flat. Impressions of ribs preserved only in the anterior half of the internal mould. Impressions of bifurcation of ribs on the fold hardly preserved. Impressions of growth lamellae well developed close to the anterior margin of the internal mould.

Geographic and stratigraphic occurrence. - Eastern North America (New York, Maryland, Canada); Oriskany Sandstone, Ridgeley Member, ?Onondaga Limestone, Grande Grève Limestone, Oriskanian ( Pragian) to ?Emsian (middle to ?upper Lower Devonian).

Subfamily Multiplicatispiriferinae Schemm-Gregory, 2008c

\section{Genus Multiplicatispirifer Schemm-Gregory, 2008c}

Type species. - Multiplicatispirifer foumzguidensis Schemm-Gregory, 2008c.

Diagnosis. - Large and in longitudinal section ventribiconvex spiriferids with fine bifurcating ribs on flanks, sulcus, and fold. Sulcus inconspicuous. Septal pillow present. Dental plates long and thin. Micro-ornamentation capillate consisting of capillae and fila. Capillae pseudoradially arranged and concavely curved outwards, diverging from the costal furrows towards the top of the ribs.

Species assigned. - Multiplicatispirifer foumzguidensis Schemm-Gregory, 2008c, Spirifer weisbordi Harris in Liddle et al., 1943.

Geographic and stratigraphic occurrence. - Anti-Atlas Mountains, Dra Valley, Morocco, ?Venezuela; Lower/Upper Emsian boundary succession in the classical German sense (upper Lower Devonian).

\section{Multiplicatispirifer foumzguidensis Schemm-Gregory, 2008c}

Figures 2F, 4G, 5, 23

1964 Fimbrispirifer (?) sp. - Drot, pp. 64, 65, pl. 5, figs 6d, $7,8$.

2004 Struveina sp. (large forms). - Jansen in Jansen et al., p. 23.

2008c Multiplicatispirifer foumzguidensis. - Schemm-Gregory, pp. 389-393, figs 3, 4, 5A-F.

Holotype. - Internal mould of articulated specimen with incomplete external mould stored under inventory number
SMF 66484a, b. Width of the articulated internal mould $51.9 \mathrm{~mm}$ and thickness $30.0 \mathrm{~mm}$; length of the ventral internal mould $43.1 \mathrm{~mm}$ and $38.3 \mathrm{~mm}$ of the internal dorsal mould, length of the external mould $39.2 \mathrm{~mm}$ and width $46.3 \mathrm{~mm}$.

Type horizon and locality. - Unit 16 of section Foum Zguid III sensu Jansen (2001a), respectively, Unit 9 sensu Jansen et al. (2004), Mdâouer-el-Kbîr Formation, Lower/Upper Emsian boundary interval in the classical German sense (upper Lower Devonian); Slope of the hill 'El Haïdoûrîya', section Foum Zguid III. Detailed description see Jansen (2001a) and Jansen et al. (2004).

Material. - 1 articulated internal mould with corresponding ventral external mould: SMF 66484a, b (holotype); 4 articulated specimens: SMF 66485-66488; 20 ventral internal moulds: 66489, 66491-66501, 66502/1, 66502/3, 66503-66505/1; 5 dorsal internal moulds: SMF 66506-66510; 2 ventral external moulds: 66502/2, 66505/2; 1 fragment of a ventral internal mould: SMF 66512.

Diagnosis. - See genus which is at present monospecific.

Description. - Form and size: shells large-sized, ventribiconvex in longitudinal section, brachythyrid without mucronate cardinal extremities, and semielliptical in outline. Exterior of ventral valve: ventral interarea high, apsacline, and curved. Delthyrium open, but constricted by thin deltidial lamellae that do not build a deltidium. Exterior of dorsal valve: dorsal interarea low, anacline, and curved. Notothyrium open, chilidial lamellae not developed. Coarse ornamentation: surface covered by numerous fine, bifurcating ribs on flanks as well as on sulcus and fold that are separated by more narrow furrows. Furrows and ribs are rounded in cross section. Ribs bifurcate at different growth stages (Fig. 4G). Sulcus inconspicuous, broad, and deep with median costa bifurcating for the first time in the posterior part. Sulcus at base rounded in cross section. Median rib in sulcus bifurcates followed by an intercalation of a new rib, etc. (Fig. 5). Fold inconspicuous, flattened on top, and moderately elevated. Growth lamellae very fine and mostly only weakly preserved. Micro-ornamentation: capillate with fila; ribs and furrows are covered with very fine capillae that multiply by intercalation. Capillae are pseudoradially arranged and even concavely curved outwards diverging from the costal furrows to the top of ribs (Fig. 2F). Interior of ventral valve: ventral muscle field extending posteriorly over the hinge line. Lateral apical cavities are weakly constricted by secondary shell material, extending also posteriorly over the hinge line and reaching almost as far as the ventral muscle field. A septal pillow is developed beneath the ventral muscle field, clearly bordered to the anterior by a distinct groove on 

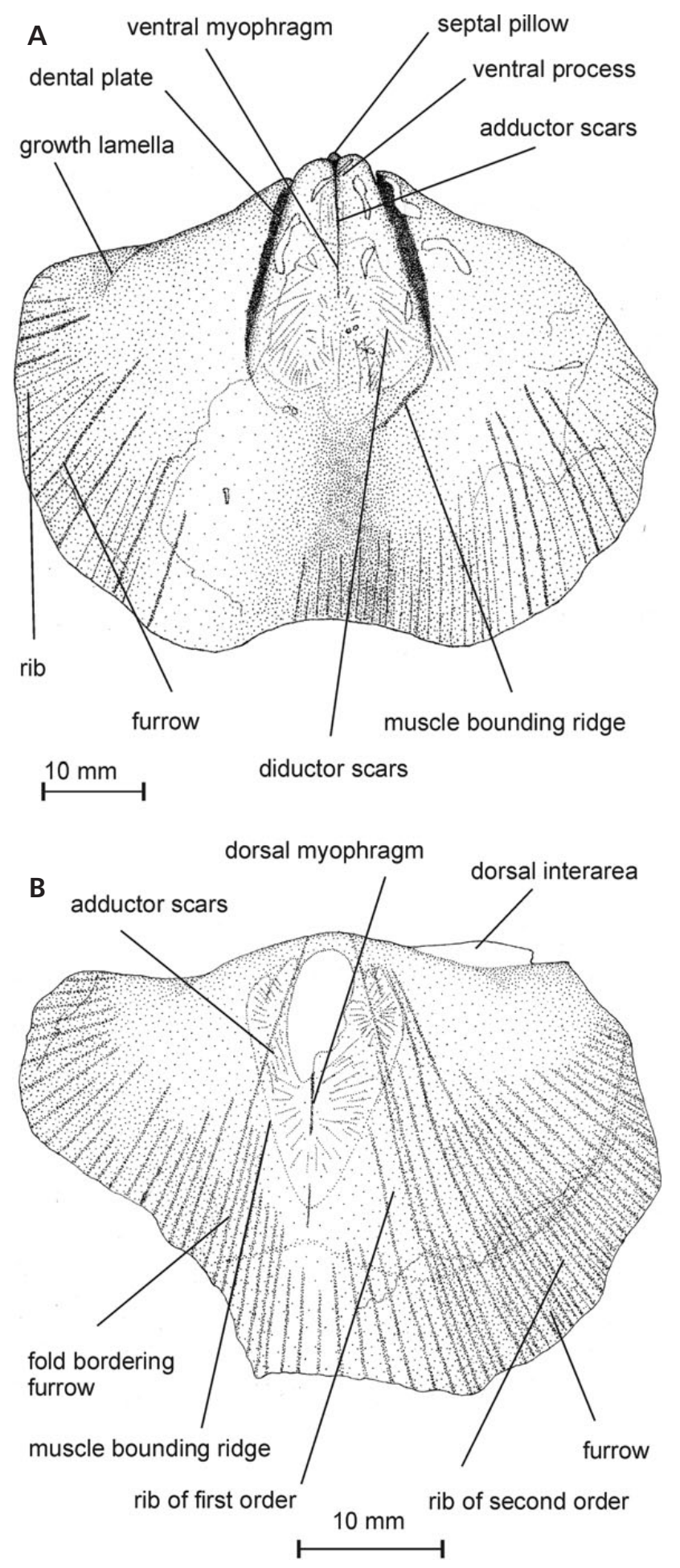

the internal mould. Both sides of the septal pillow are bordered by a thin subdeltidial furrow on the internal mould. Ventral process weakly developed leaving a very small groove on the internal mould. A thin myophragm extends from the ventral process leaving a thin furrow through the whole ventral muscle field on the internal mould. The ventral muscle field is thin, elongate, and not impressed into shell material.

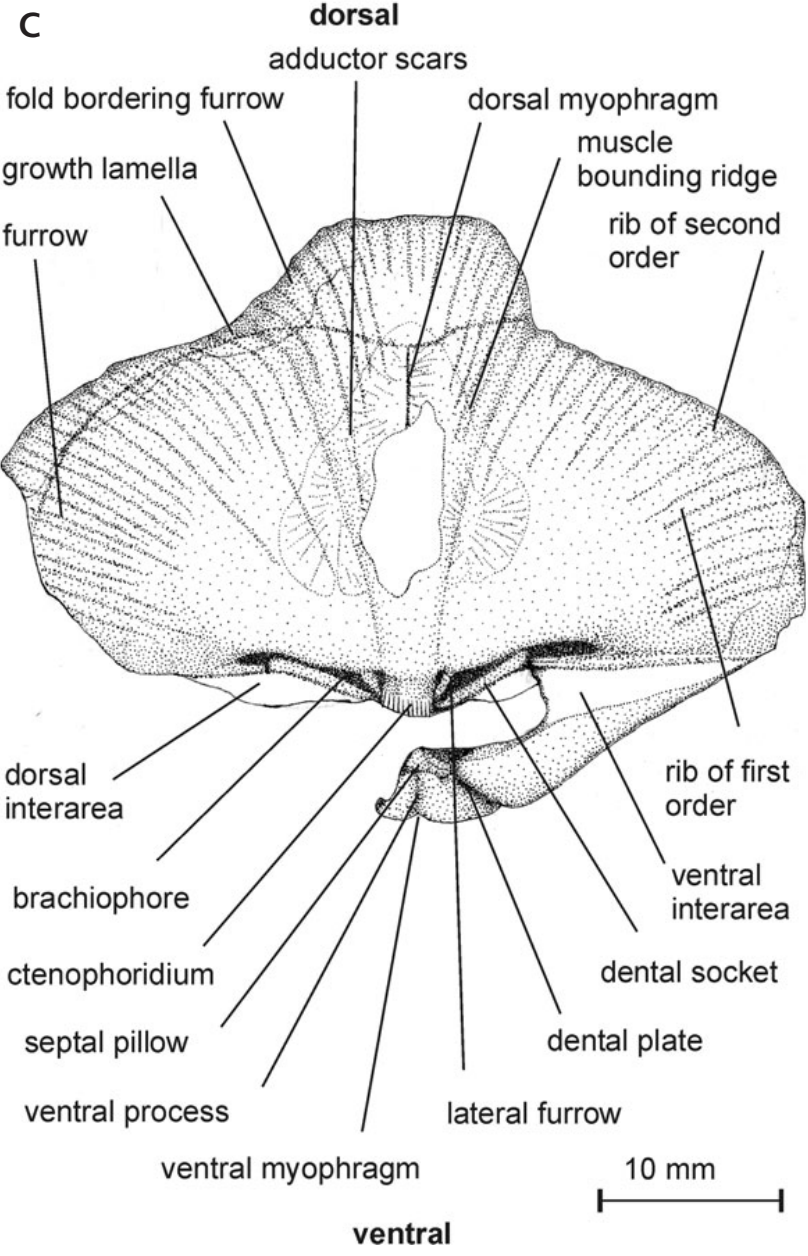

Figure 23. Morphological terms of Multiplicatispirifer foumzguidensis (Schemm-Gregory, 2008c). • A - SMF 66489. Ventral internal mould, plan view. $・$ B , C - SMF 66484a (holotype). Internal mould of articulated specimen, plan (B) and oblique posterior (C) views on dorsal valve. Dental plates, ventral process, septal pillow, muscle bounding ridge, ventral and dorsal myophragms, dental sockets, brachiophores, and lateral furrows are preserved as negative forms.

No ribs are impressed on the internal mould of the ventral muscle field. Diductor scars preserved as subradial striae on the internal mould; at the anterior margin of the ventral muscle field striae in longitudinal direction are impressed. Adductor scars elongate, posterior and anterior pairs clearly differentiable. Both are clearly impressed into the internal mould. Muscle bounding ridge absent or weakly developed, in a very few specimens leaving a fine furrow on the internal mould. Free portions of dental plates long and very thin, situated on the lateral border of the sulcus, leaving divergent slits on the internal mould. Gonoglyphs are not preserved. Sulcus inconspicuous, at base rounded to flattened in cross section, and with median rib. Impressions of ribs weakly developed, in most cases only peripherally preserved. Bifurcation of ribs faintly impressed on the internal mould. Furrows are finer than ribs. Impressions of growth lamellae 


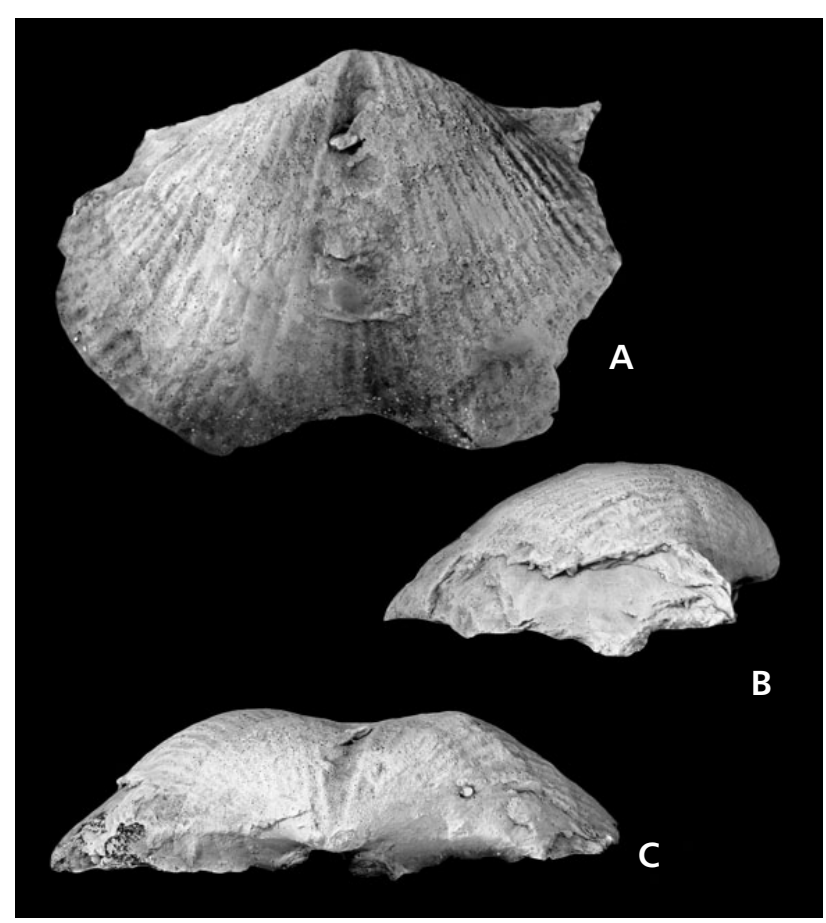

Figure 24. ?Multiplicatispirifer weisbordi (Harris in Liddle et al., 1943). Locality and stratum: Perijá District, Sierra de Perijá, Venezuela; Caño de Oeste Formation, ?Emsian (?upper Lower Devonian), coll. J.M. Bowen. Ventral external shell. All figures are at original size $(\times 1.0)$, unless otherwise stated. - A-C - NHM BB 47276. (= plaster cast SMF 99934.) Plan (A), lateral (B), and posterior (C) views.

recognisable at the anterior margin. Interior of dorsal valve: filling of the umbo extends posteriorly over cardinalia and for a short distance over the hinge line. Hardly any secondary shell material developed in apical region. Notothyrial shelf lacking. Ctenophoridium situated beneath the filling of the umbo, covered by 24 to 31 lamellae and bordered by two fine and thin furrows leaving a small ridge on either side on the internal mould. Dorsal median process weakly developed, situated dorsally of the ctenophoridium. It is followed by a fine myophragm that extends through the entire muscle field. Dental sockets cylindrical, thin, long, and almost parallel to hinge line. Brachiophores long and thin, pointing in an apical direction. Crural bases not recognisable. Outline of adductor field 'teardrop'-like, inconspicuously defined. In a few places elongate striae are impressed on the internal mould. Adductor scars situated on the fold and also in the posterior part lateral of it. Fold moderately elevated and with median furrow. Ribs impressed at the anterior two thirds of the dorsal internal mould on the flanks and on the fold. Bifurcation of ribs hardly recognisable. Gonoglyphs are not preserved. Impressions of growth lamellae preserved at the anterior margin.

Stratigraphic and geographic occurrence. - See type horizon and type locality.
Discussion. - The genus Multiplicatispirifer was described as monospecific, however, in the J.M. Bowen collection at the Natural History Museum, an external ventral valve was found that could be determined as ?Multiplicatispirifer weisbordi (Fig. 24). This specimen was found in the Sierra de Perijá, Venezuela, and is the only find of a representative of Multiplicatispirifer outside of North Africa. Even though the micro-ornamentation and internal features are unknown it can be considered as belonging to Multiplicatispirifer. It differs from $M$. foumzguidensis in gently coarser ribs and a shallower and broader sulcus. The ribs in the sulcus of ?M. weisbordi are gently finer than ribs on the flanks whereas ribs on sulcus and on flanks are of same size in $M$. foumzguidensis. The occurrence of ?M. weisbordi in Venezuela which belongs together with eastern North America to the Eastern American Realm verify the argumentation for a pathway between America and North Africa around the Siegenian/Emsian interval (Michard 1976, SchemmGregory 2008c).

Family Elymospiriferidae Johnson \& Hou in Carter et al., 1994

Type genus. - Elymospirifer Wang in Wang et al., 1974.

Diagnosis. - Shells small to large-sized with transverse subquadrate outline. Fold, sulcus, and flanks with bifurcating and trifurcating ribs. Micro-ornamentation capillate with short, rounded micro-spines. Deltidial lamellae extending to posterior. Crural plates clearly developed. Notothyrial shelf lacking.

Genera assigned. - Elymospirifer Wang in Wang et al., 1974, Perryspirifer Jones \& Boucot, 1983, Borealispirifer Hou \& Su in Su \& Hou, 1993.

Genera excluded. - Multispirifer Kaplun, 1961.

Remarks. - As well as the Costispiriferidae, the Elymospiriferidae are characterised by a capillate micro-ornamentation and its assignment to the Acrospiriferidae is rejected. Their differences in style of ribbing, development of their ventral muscle field and the weaker development of secondary shell material compare to some taxa of the Costispiriferidae, their clear development of crural plates, and the capillate micro-ornamentation with micro-spines versus the capillate micro-ornamentation without micro-spines of the Costispiriferidae justify the raising to family level.

Discussion. - The genus Multispirifer Kaplun, 1961 is removed from the Elymospiriferidae because of its more transverse outline and the development of mucronate ex- 
tremities, and is here assigned to a new family Multispiriferidae. The coarse-ornamentation in multispiriferidids with its bifurcating and trifurcating 'bundled' ribs of unequal size depending on growth stage is different from the bifurcating and sometimes trifurcating ribs in the Elymospiriferidae, which show almost the same size at every growth stage. The cardinalia in Multispiriferidae are very coarse and clearly developed; in Elymospiriferidae the cardinalia are somewhat smaller, finer, and mostly overhung by the filling of the dorsal umbo. In Multispiriferidae the cardinalia are situated on an elevated 'shelf' as discussed above. The micro-ornamentation of Multispiriferidae consists of capillae with larger micro-spines than in Elymospiriferidae.

The relationship to the family Costispiriferidae is described above.

Geographic and stratigraphic occurrence. - Kazakhstan, Taimyr, China; Canadian Arctic Islands; Pragian to Eifelian (middle Lower Devonian to lower Middle Devonian).

\section{Genus Elymospirifer Wang in Wang et al., 1974}

Type species. - Indospirifer kwangsiensis Hou, 1959, p. 458.

Emended diagnosis. - Medium to large-sized shells, equibiconvex to mostly ventribiconvex in longitudinal section, subrectangular in outline. Ventral interarea curved and apsacline. Ribs and furrows are rounded in cross section. Micro-ornamentation of variably developed radial striations interrupted by fine and narrow growth lines, short rounded micro-spines may be present at the edge of the growth lamellae. Dental plates long. Hardly any development of secondary shell material in apical region. Crural plates short.

Species assigned. - At present only the type species Indospirifer kwangsiensis Hou, 1959.

Discussion. - Jones \& Boucot (1983) separated Elymospirifer from the Fimbrispiriferidae due to the lack of microspines and the presence of capillae. However, on some Elymospiriferidae, either in Elymospirifer or in Perryspirifer (type species: Spirifer scheii Meyer, 1913) (Fig. 25), short and rounded micro-spines are developed at the end of the capillae pointing in an anterior direction.

In contrast to Elymospirifer, Perryspirifer is characterised by the lack of crural plates, however, Brice (1982, pl. 17, fig. 11) shows that slits after crural plates or at least remains of crural plates can be found on dorsal internal moulds. In Elymospirifer, the crural plates are well developed. The apical region of Perryspirifer consists of a strong development of secondary shell material, in

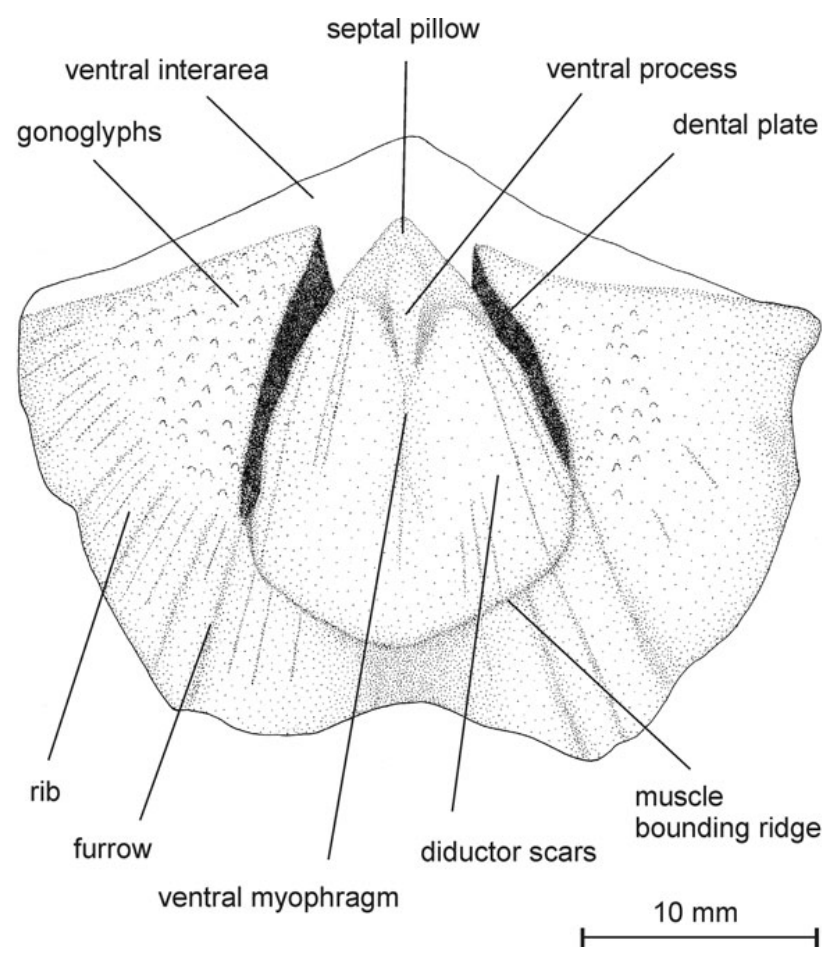

Figure 25. Morphological terms of Perryspirifer scheii (Meyer, 1913). Ventral internal mould, UA 3939, figured by Jones \& Boucot (1983, fig. $8 \mathrm{Z}$ ), plan view. Dental plates, ventral process, myophragm, gonoglyphs, and muscle bounding ridge are preserved as negative forms.

Elymospirifer it is almost lacking. Both genera have a capillate micro-ornamentation but the micro-spines at the edge of the growth lamellae seem to be longer in Perryspirifer than in Elymospirifer, although the median rib in the sulcus is lacking in Perryspirifer. The coarse-ornamentation of Perryspirifer is the same as that of Elymospirifer considering the multiplication of ribs. Both genera show pronounced deltidial lamellae extending posteriorly as they are typical for the "Asian clade of delthyridoid spiriferids" (Schemm-Gregory in press).

Taxa of Borealispirifer [type species: Eospirifer (Multispirifer) bifurcatus Kaplun, 1961] (Fig. 26) are more strongly convex and sometimes even dorsibiconvex in longitudinal sections. Partly they show a strong development of secondary shell material in the ventral apical region that is less developed in Elymospirifer and Perryspirifer. The dental plates in Borealispirifer are straight but also tend to be intrasinal and curved in a median direction whereas in Elymospirifer and Perryspirifer they are straight, extrasinal, or situated on the sulcus bordering ribs. Considering these differences it is suggested that it is necessary to study the type material of Borealispirifer and compare it with the two elymospiriferid genera. It is very certain, based on comparison of the illustrations given by Kaplun (1961), Kaplun \& Krupchenko (1991), and illustrations given by Hou \& Su (in Su \& Hou 1993), that taxa assign- 

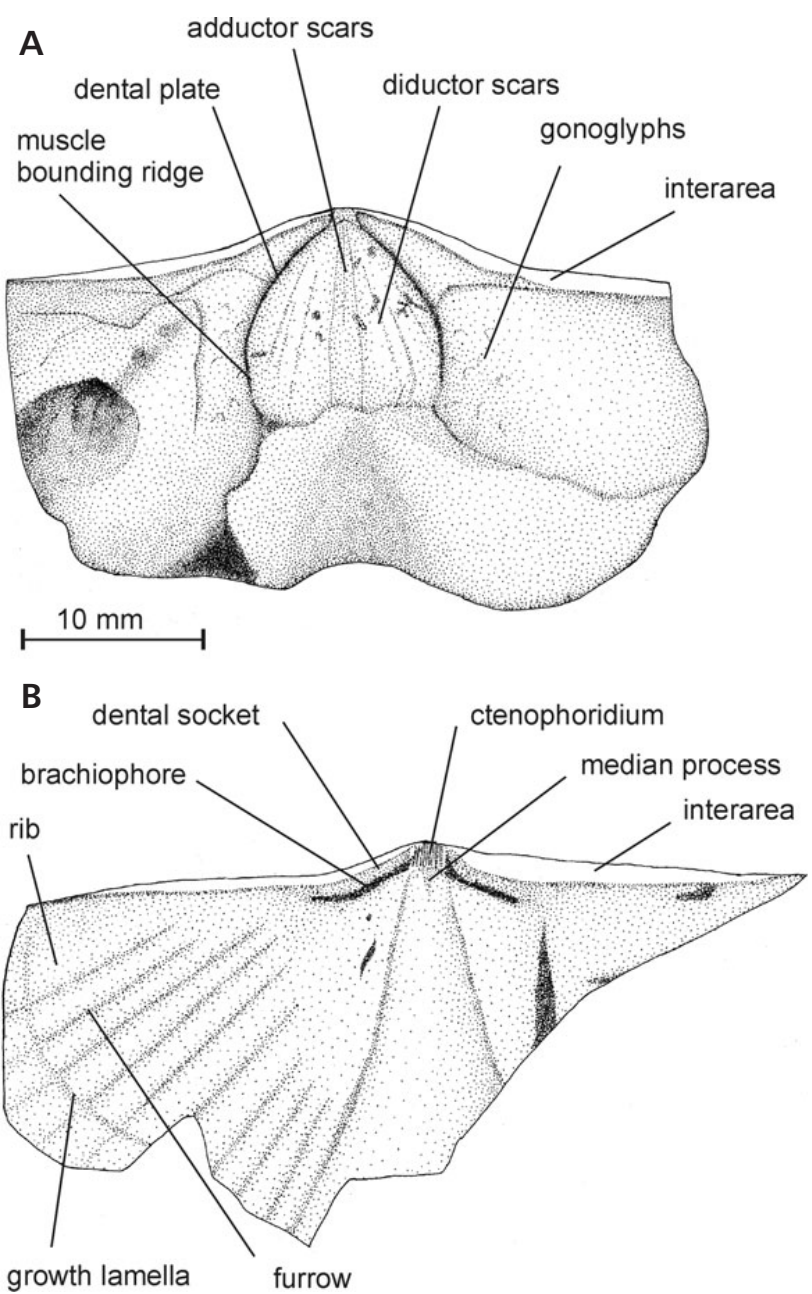

Figure 26. Morphological terms of Borealispirifer bifurcatus (Kaplun, 1961). • A - ventral internal mould, figured by Kaplun (1961, pl. 14, fig. 1), holotype, plan view. Dental plates, myophragm, gonoglyphs, and muscle bounding ridge are preserved as negative forms. $\bullet \mathrm{B}-$ dorsal internal mould, figured by Kaplun (1961, pl. 14, fig. 2), plan view. Dental sockets, brachiophores, and median process are preserved as negative forms.

able to Borealispirifer belong to more than one genus, e.g., comparing the low curvature and the strong development of secondary shell material. One example is given in gen. nov. A maximus (Zhang, 1983) (Fig. 27) with little secondary shell material and the strongly biconvex curvature of B. bifurcatus (Hou \& Su in Su \& Hou 1993, pl. 1, figs 2, 3). The ventral muscle field of $B$. bifurcatus is shorter and wider than in gen. nov. A which is regarded as a potentially different genus from Borealispirifer in this work. Nonetheless, it is desirable to study the type material to clarify the relationship of these taxa to each other and their systematic position.

Geographic and stratigraphic occurrence. - Taimyr and Autonomous Region Guangxi, South China; Lower Emsian (upper Lower Devonian).

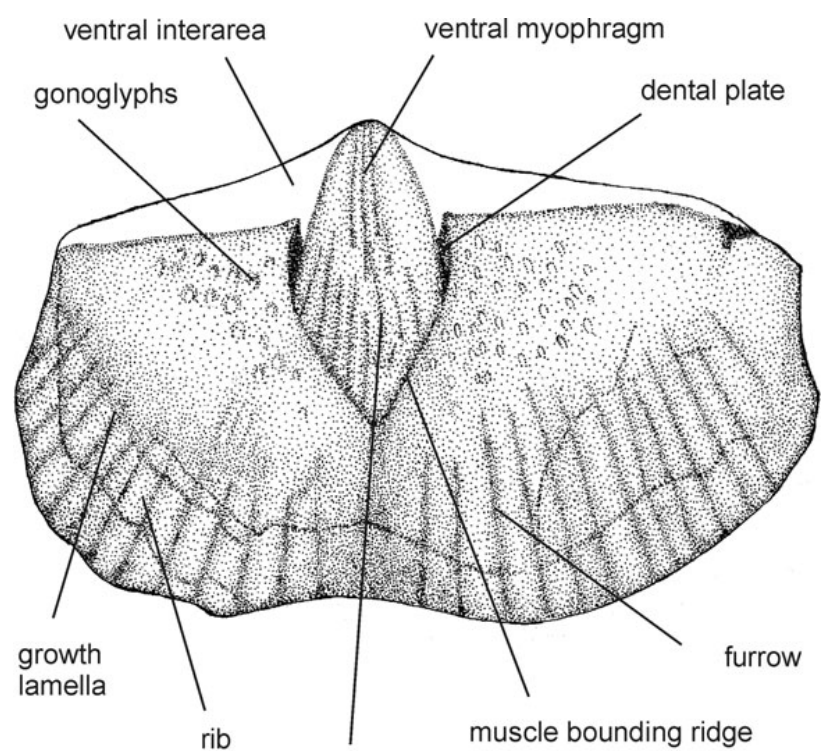

diductor scars

$10 \mathrm{~mm}$

Figure 27. Morphological terms of gen. nov. A maximus (Zhang, 1983). NS 913512. Ventral internal mould, figured by Hou \& Su in Su \& Hou (1993, pl. 1, fig. 2), plan view. Dental plates, myophragm, gonoglyphs, and muscle bounding ridge are preserved as negative forms.

\section{Elymospirifer kwangsiensis (Hou, 1959)}

Figures 2H, 4H, 5, 28

1959 Indospirifer kwangsiensis Hou; Hou, pp. 458, 459, pl. 3 , fig. 5 .

1974 Elymospirifer kwangsiensis (Hou). - Wang in Wang et al., p. 40, pl. 7, figs 6-14.

1975 Elymospirifer kwangsiensis (Hou). - Hou \& Xian, p. 71, pl. 16, figs 1-6.

1983 Elymospirifer kwangsiensis (Hou). - Jones \& Boucot, pp. 337, 339, figs 2I-W, 9.

1986 Elymospirifer kwangsiensis (Hou). - Wang \& Rong, pp. 199, 200, pl. 73, figs $1-15$, pl. 74, figs $1-12$, pl. 75 , figs $1-13$, pl. 77 , figs $1-12$, pl. 95 , fig 10 , text-figs 103-105.

Holotype. - Articulated specimen, figured by Hou (1959, pp. 458, 459, pl. 3, fig. 5) and stored under inventory number IV 426 [IV02960]. The holotype is $40.3 \mathrm{~mm}$ wide, $25.4 \mathrm{~mm}$ long, and $21.8 \mathrm{~mm}$ thick.

Type horizon and locality. - Yukijang Formation, Lower Emsian (upper Lower Devonian); Liujing Section, Liujing, Autonomous Region Guangxi, South China.

Material. - Locality and stratum: see type horizon and locality. 3 articulated specimens: IV 426 [IV02960], SMF 66618 , unnumbered specimen in the Biological Collection 
of USNM (a plaster cast of this specimen is stored under inventory number SMF 66620).

Diagnosis. - See genus which is at present monospecific.

Description. - Form and size: shells transverse and brachythyrid without mucronations. Outline subelliptical to subtriangular. Equibiconvex to ventribiconvex in longitudinal section. Exterior of ventral valve: ventral area apsacline, moderately to very high, and strongly curved. Deltidial lamellae well developed, clearly extending posteriorly and fused in the posterior part to form a small deltidium. Sulcus broad, deep, and in cross section rounded to almost flat at its base with moderately steep flanks. Exterior of dorsal valve: dorsal interarea low and orthocline. Notothyrium and chilidial lamellae not visible. Dorsal shell strongly convex in longitudinal section. Fold gently elevated compared to neighbouring flanks. Coarse ornamentation: first to third pair of ribs of flanks bifurcating, rarely trifurcating in the anterior half. In a few specimens more laterally situated ribs also bifurcate (Fig. 4H). Sulcus with median rib. Sulcus bordering ribs are the coarsest ribs of the ventral valve. Bifurcation of ribs occurs only in the sulcus bordering ribs into the sulcus (Fig. 5). Fold with median furrow. Bifurcation of ribs on fold from the bordering ribs to median, rarely bifurcation from median pair of ribs on fold (Wang \& Rong 1986, pl. 75, fig. 11). Ribs of second order smaller than those of first order on flanks, on fold, and in sulcus. Growth lamellae well developed at anterior margin. Micro-ornamentation: capillate, sometimes micro-spines pointing anteriorly on the edge of each growth lamella (Wang \& Rong 1986, pl. 75 , figs 10,13 and studied by the present author on the holotype) (Fig. 2H). Interior of ventral valve: Filling of ventral umbo extends posteriorly over the hinge line. Almost no development of secondary shell material in the apical region. Fillings of lateral apical cavities reaching almost to the posterior margin of the ventral muscle field. Ventral process very small leaving a fine indentation on the internal mould. No septal pillow developed. Ventral muscle field elongated and thin. Anterior margin of muscle field inconspicuous, neither a muscle bounding ridge nor muscle scars preserved. Dental plates long and thin. Teeth small and knob-like. Impressions of ribs well developed, starting almost at the posterior end of the internal mould. Bifurcation of ribs not preserved, instead impressions of ribs seem to multiply by intercalation. Interior of dorsal valve: ctenophoridium thin. Notothyrial shelf lacking. Crural plates long and moderately thick. Dorsal median process very small. Out of it extends a very fine and short myophragm to anterior. Outline of the adductor field inconspicuous. Impressions of ribs similar to those in ventral valve.

Geographic and stratigraphic occurrence. - See genus.

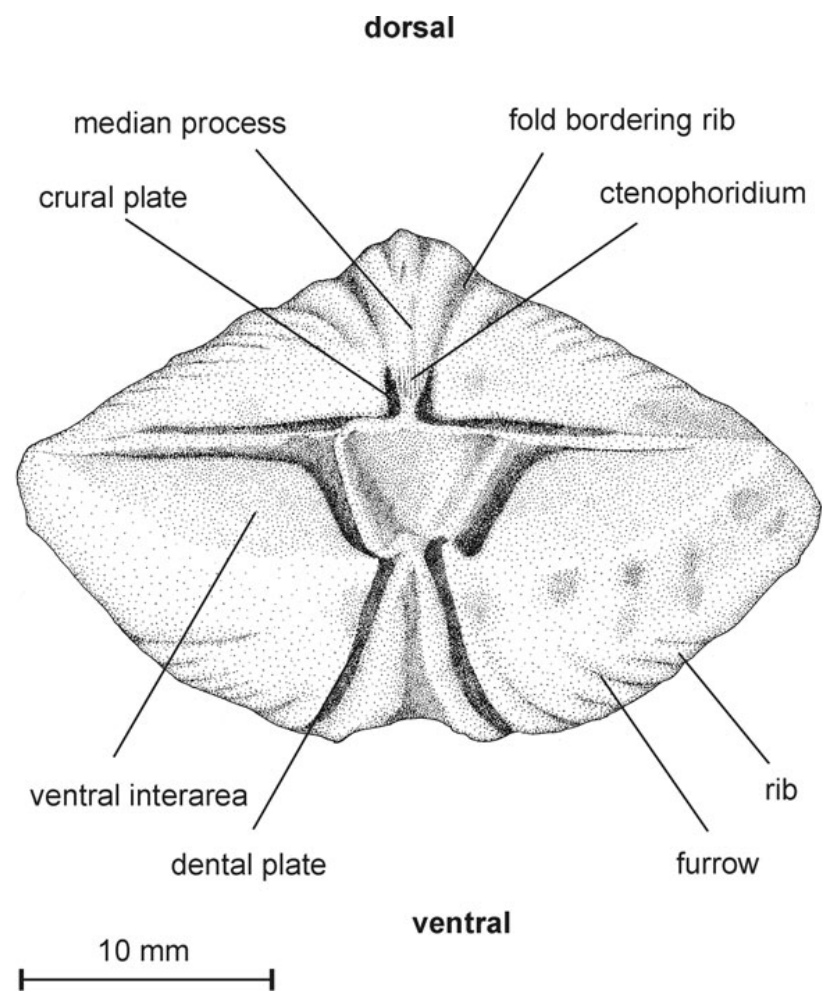

Figure 28. Morphological terms of Elymospirifer kwangsiensis (Hou, 1959). NIGP 88168. Internal mould of articulated specimen, figured by Wang \& Rong (1986, pl. 73, fig. 14), posterior view. Dental plates, ventral process, dorsal and ventral myophragm, and crural plates are preserved as negative forms.

\section{Genus Perryspirifer Jones \& Boucot, 1983}

Type species. - Spirifer scheii Meyer, 1913, p. 25.

Emended diagnosis. - Shells medium-sized, transverse with rounded cardinal angles, and equibiconvex to ventribiconvex in longitudinal section. Fold and sulcus prominent and with bifurcating ribs. Ribs on flanks bifurcate or trifurcate. Micro-ornamentation capillate with micro-spines at the edge of each growth lamellae. Free portions of dental plates wedge-like. Strong development of secondary shell material in apical region. Vestigial crural plates present.

Species assigned. - At present only the type species Spirifer scheii Meyer, 1913 (= Perryspirifer pseudoscheii Brice, 1982, Perryspirifer fascicostatus Brice, 1982).

Discussion. - Jones \& Boucot (1983) have statistically studied about 1,000 specimens of Perryspirifer from the Canadian Arctic Islands and proved that this species shows a lot of intraspecific variability in morphologic features, e.g., number of plications or size of shells. I follow the intention of these authors and include $P$. pseudoscheii and P. fascicostatus into $P$. scheii. 
Geographic and stratigraphic occurrence. - Canadian Arctic Islands; upper Lower Emsian to Eifelian (upper Lower Devonian to lower Middle Devonian).

\section{Perryspirifer scheii (Meyer, 1913)}

Figures 5, 25

1913 Spirifer scheii Meyer; Meyer, pp. 25, 26, pl. 5, fig. 7, pl. 6, fig. 1a-c.

1982 Fimbrispirifer scheii (Meyer, 1913). - Brice, pp. 72-75, fig. 22, pl. 17, figs 1-11.

1982 Fimbrispirifer?pseudoscheii Brice; Brice, pp. 73-77, fig. 23, pl. 18, figs $1-3,6-8$.

1982 Fimbrispirifer fascicostatus Brice; Brice, pp. 77-81, fig. 24, pl. 18, figs 4, 5, pl. 19, figs 1-7, 9 .

1983 Perryspirifer scheii (Meyer, 1913). - Jones \& Boucot, pp. 339-343, figs 3R-AK, 4-6, 8A-Z, 10, 11.

Lectotype. - Articulated shell selected by Brice (1982, p. 72 , pl. 17, figs 1a-e) and stored under inventory number PMO A18820. The lectotype is $40.8 \mathrm{~mm}$ wide, $27.5 \mathrm{~mm}$ long, and $26.3 \mathrm{~mm}$ thick.

Type horizon and locality. - Blue Fiord Formation, Upper Emsian (upper Lower Devonian); southeast of Ellesmere Island, Arctic Canada.

Material. - Observations are made based on descriptions and figures illustrated by Brice (1982) and Jones \& Boucot (1983).

Diagnosis. - See genus which is at present monospecific.

Description. - See Jones \& Boucot (1983, pp. 339-343).

Geographic and stratigraphic occurrence. - Eids to Bird Fiord formations, upper Lower Emsian to Eifelian (upper Lower to lower Middle Devonian).

\section{Genus Borealispirifer Hou \& Su in Su \& Hou, 1993}

Type species. - Eospirifer (Multispirifer) bifurcatus Kaplun, 1961, p. 91.

Diagnosis. - Medium of large-sized, strongly biconvex, with slightly acute cardinal angles. Ventral interarea low. Fold and sulcus broad and not sharply bounded. Flanks with bifurcating ribs. Dental plates intrasinal. Rare development of secondary shell material in apical region. Vestigial crural plates present.

Species assigned. - Eospirifer (Multispirifer) bifurcatus
Kaplun, 1961 [= Eospirifer (Multispirifer) aff. solitarius (Krantz, 1857) sensu Kaplun (1961), Multispirifer pseudodivaricatus Kaplun, 1961], Eospirifer (Multispirifer) bifurcatus var. plana Kaplun, 1961.

Species excluded. - Borealispirifer maximus (Zhang, 1983).

Discussion. - The species maximus was excluded from Borealispirifer due to its differences in curvature and development of secondary shell material. It is erected as the type species of gen. nov. A., which is less convex, very transverse, and equiconvex in longitudinal section, whereas taxa of Borealispirifer are equibiconvex to dorsibiconvex in longitudinal section and less transverse. The new genus shows strong development of secondary shell material in the apical region, Borealispirifer has hardly any development of secondary shell material in apical region. The ventral muscle field of gen. nov. A is more elongated than the ventral muscle field in Borealispirifer.

The comparison of Borealispirifer with Elymospirifer and Perryspirifer is described above.

Geographic and stratigraphic occurrence. - Kazakhstan and northern China; Pragian to Lower Emsian (middle to upper Lower Devonian).

\section{Borealispirifer bifurcatus (Kaplun, 1961)}

Figures 5, 26

1961 Eospirifer (Multispirifer) bifurcatus Kaplun; Kaplun, pp. 91, 92, pl. 14, figs 1-4.

1961 Eospirifer (Multispirifer) aff. solitarius (Krantz). Kaplun, pp. 89, 90, pl. 13, figs 6-9.

1991 Multispirifer bifurcatus (Kaplun, 1961). - Kaplun \& Krupchenko, pl. 34, figs 4a, b.

1991 Multispirifer pseudodivaricatus Kaplun; Kaplun \& Krupchenko, pp. 140-142, pl. 33, figs 1-4, pl. 34, figs 1-3.

1993 Borealispirifer bifurcatus (Kaplun, 1961). - Hou \& $\mathrm{Su}$ in Su \& Hou, p. 142, fig. 2, pl. 2, figs 4-8.

Holotype. - Ventral internal mould stored in the SKGS under inventory number Bala well collection No. 1, specimen 320. The holotype is $39 \mathrm{~mm}$ wide and $24.5 \mathrm{~mm}$ long.

Type horizon and type locality. - Sardzhal beds, Upper Emsian (upper Lower Devonian); northern Balkhash Lake, Kazakhstan.

Material. - Observations were made using the description and figures illustrated by Kaplun (1961), Kaplun \& Krupchenko (1991), and Hou \& Su (in Su \& Hou 1993). 
Diagnosis. - Medium to large-size shells, mostly dorsibiconvex in longitudinal section, and with bifurcation of ribs on flanks, fold, and in sulcus. Hardly any shell material developed in the apical region.

Description. - Form and size: shells medium-sized, equibiconvex to dorsibiconvex in longitudinal section, and subelliptical in outline. Brachythyrid without mucronations. Exterior of ventral valve: ventral interarea low, apsacline, and curved. Delthyrium open with clearly developed deltidial lamellae. Sulcus shallow, inconspicuous, and rounded in cross section. Exterior of dorsal valve: dorsal interarea very low and anacline to orthocline. Fold high, inconspicuous, and rounded in cross section. Coarseornamentation: 9 to 17 primary ribs on flanks that bifurcate and trifurcate in the anterior half of the shell. Fold and sulcus ribbed with 6 to 9 bifurcation ribs. Micro-ornamentation: capillae radially straight, forming small nodules with growth lamellae. Interior of ventral valve: filling of the umbo extends posteriorly over the hinge line. Fillings of the lateral apical cavities almost reaching as far posteriorly as the filling of the ventral umbo due to weak development of secondary shell material in apical region. Ventral muscle field broad, pyriform, without impressions of ribs, and weakly embedded into shell material. Ventral process small leaving a small indentation at the posterior margin of the muscle field on the internal mould. Out of the ventral muscle extends a fine myophragm preserved as a thin furrow through the whole muscle field. Diductor field preserved as radial striations in the anterior half of the muscle field impression which completely encloses the adductor field. Adductor field elongate, situated on each side next to the myophragm, and weakly embedded into shell material. Free portions of dental plates long leaving thin slits on the lateral margin of the muscle field of the internal mould. In gerontic stage, dental plates may be embedded into secondary shell material. A muscle bounding ridge defines the anterior margin of the muscle field preserved as a clearly developed furrow on the internal mould. In the lateral environment of the ventral muscle field, gonoglyphs are preserved as small tubercles on the internal mould. Impressions of ribs are preserved anterior of the ventral muscle field. Impressions of growth lamellae preserved in rare cases at the anterior margin. Interior of dorsal valve: ctenophoridium broad and situated perpendicular to the commissural plane. Dental sockets cone-shaped, pointing in an apical direction. Crural plates clearly developed leaving thin slits perpendicular to commissural plane on the internal mould. Adductor field inconspicuous. Impressions of ribs are preserved in the anterior two thirds of the internal mould. Impressions of growth lamellae preserved in rare cases at the anterior margin.

Geographic and stratigraphic occurrence. - See type horizon and type locality.

\section{Genus nov. A}

Proposed type species. - Fimbrispirifer maximus Zhang, 1983, p. 349.

Diagnosis. - Strongly transverse specimens with bifurcating and trifurcating ribs on flanks, fold, and in sulcus. Both valves almost flat in transverse section. Strong development of shell material in apical region. Ventral muscle field narrow, elongate, and embedded in shell material.

Species assigned. - At present only the proposed type species gen. nov. A. maximus (Zhang, 1983).

Remarks. - The outline of the new genus and the strong development of secondary shell material, as well as the thin and elongated ventral muscle field plead for the erection of a new genus. However, it was not possible to study the type material from Kazakhstan, therefore, open nomenclature is chosen.

Geographic and stratigraphic occurrence. - Eming County, Junggar, Xinjiang, PR China; Mengelu and Zuomubasite formations, Emsian (upper Lower Devonian).

\section{Gen. nov. A maximus (Zhang, 1983)}

Figures 5, 27

1983 Fimbrispirifer maximus Zhang; Zhang, p. 349, pl. 97, fig. 5.

1993 Borealispirifer maximus (Zhang, 1983). - Hou \& Su in Su \& Hou, pp. 143, 144, pl. 1, figs 1-4.

Type horizon and type locality. - Mengkelu Formation, Emsian (upper Lower Devonian); Eming County, western Junggar, Xinjiang, PR China.

Material. - Description made using the account and figures of Hou \& Su in Su \& Hou (1993).

Diagnosis. - See genus which is at present monospecific.

Description. - Form and size: shells medium to largesized, equibiconvex to ventribiconvex in longitudinal section, strongly transverse, and subelliptical in outline. Both valves flattened. Brachythyrid without mucronations. Exterior of ventral valve: ventral interarea low, apsacline, and curved. Sulcus shallow, inconspicuous, and rounded in cross section. Exterior of dorsal valve: dorsal interarea orthocline to anacline. Fold low, inconspicuous, and rounded in cross section. Coarse-ornamentation: flanks, sulcus, and fold covered by fine, bifurcating 
ribs separated by narrower furrows. Bifurcation in general in the posterior part of the shell. Fold with median furrow. Sulcus with median rib (Fig. 5). Micro-ornamentation: according to Hou \& Su in Su \& Hou (1993, p. 143), Zhang (1983, p. 349) described the micro-ornamentation as fimbriate, consisting of lines of micro-spines at the edge of each growth lamella. Interior of ventral valve: filling of the ventral umbo extending gently posteriorly over the hinge line. Ventral muscle field strongly embedded into shell due to strong development of secondary shell material in apical region. Ventral muscle field elongated, longer than wide, and diamond-shaped. Myophragm fine, reaching through the posterior half of the muscle field. Ventral muscle field smooth, without any impressions of ribs. Free portions of dental plates short, leaving short, thin slits, or even only indentations, on either side of the impression of the ventral muscle field on the internal mould. Muscle bounding ridge clearly developed, leaving a coarse furrow on the internal mould that is sharply converging to anterior in the impression of the sulcus. Gonoglyphs coarse and embedded into the shell, preserved as elongated tubercles on the surface of the internal mould in the lateral environment of the ventral muscle field. Impressions of ribs preserved in the anterior third of the internal mould. Bifurcation of ribs not visible. Impressions of growth lamellae at the anterior margin.

Stratigraphic and geographic occurrence. - See genus which is monospecific.

Family Multispiriferidae fam. nov.

Type genus. - Multispirifer Kaplun, 1961.

Diagnosis. - Large spiriferids with mucronations. 'Bundled' ribs that anteriorly bifurcate and trifurcate on flanks, fold, and sulcus. Cardinalia large and coarsely developed, situated on an elevated platform in the same plane with the dorsal interarea. Crural plates lacking, moderate development of secondary shell material in apical region. Micro-ornamentation capillate, some specimens showing marginal, long micro-spines at the edge of each growth lamella.

Geographic and stratigraphic occurrence. - Germany and Belgium; Middle Siegenian (middle Lower Devonian).

\section{Genus Multispirifer Kaplun, 1961}

Type species. - Spirifer solitarius Krantz, 1857.

Diagnosis. - See family.
Species assigned. - Only the type species Multispirifer solitarius (Krantz, 1857).

Geographic and stratigraphic occurrence. - See family.

\section{Multispirifer solitarius (Krantz, 1857)}

Figures 2I, 4I, 5, 29

1857 Spirifer solitarius n. sp. Krantz; Krantz, pl. 9, fig. 1a [non 1b].

1900 Spirifer solitarius Krantz, 1857. - Scupin, pp. 11, 12 [215, 216], pl. 1 [24], figs 1, 2a-d.

1904 Spirifer solitarius Krantz, 1857. - Drevermann, pp. 249-251, pl. 22, figs 8-13.

1934 Spirifer solitarius Krantz, 1857. - Dahmer, p. 11, 17, $31,33$.

1935 Spirifer solitarius Krantz, 1857. - Dahmer, p. 140.

non 1961 Eospirifer (Multispirifer) aff. solitarius. - Kaplun, pp. 89, 90, pl. 8, figs 6-9.

1963 Acrospirifer solitarius (Krantz, 1857). - Vandercammen, pp. 19-24, pl. 3, figs 13-20.

Holotype. - Ventral internal mould designated by monotypy stored under inventory number IPB A. Krantz, No. 5a, A. Krantz collection (illustrated by Krantz 1857, pl. 9, fig. 1a). Width $65.0 \mathrm{~mm}$ and length $37.5 \mathrm{~mm}$.

Type horizon and locality. - Middle Siegen Beds (middle Lower Devonian); abandoned quarry close to Menzenberg (TM Königswinter 5309) near Bad Honnef (Middle Rhine area, Germany).

Material. - Locality and stratum: different localities in the Rheinisches Schiefergebirge, Germany; Middle Siegen beds, mid-Siegenian (middle Lower Devonian). 7 ventral internal moulds with corresponding external mould: Mbg. 3976; SMF XVII 820c, XVII 820d, XVII 1725a, 66337; 4 ventral internal moulds: SMF XVII 820b, XVII 820c, 66337, 66608; 2 ventral external mould: IPB AS Krantz Nr. 5a (holotype); SMF 66609; 2 dorsal internal moulds with corresponding external mould: SMF XVII 820c; 6 dorsal internal moulds: Mbg. 3978; SMF XVII 820c, 66611, 66339; 4 dorsal external moulds: Mbg. 3979, SMF 66610, 66612, 66336.

Diagnosis. - See subfamily.

Description. - Form and size: shells large, transverse, outline subelliptical, and brachythyrid with mucronations; almost equibiconvex to gently ventribiconvex in longitudinal section. Exterior of ventral valve: ventral interarea high, catacline, and often curved, mostly with strong and transverse growth lamellae. Delthyrium open, often with clearly developed deltidial lamellae that form a small 


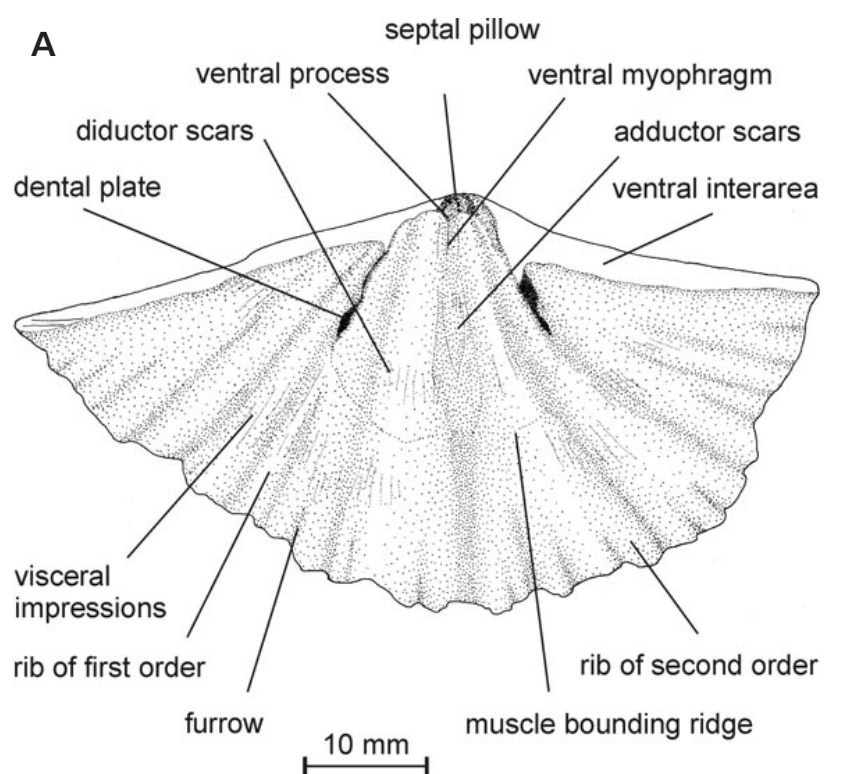

Figure 29. Morphological terms of Multispirifer solitarius (Krantz, 1857). • A - SMF 66337. Ventral internal mould, plan view. Dental plates, ventral process, septal pillow, myophragm, and muscle bounding ridge are preserved as negative forms. • B, C - SMF 66639. Dorsal internal mould, plan (B) and oblique posterior (C) views. Dental sockets, brachiophores, lateral furrows, median process, and muscle bounding ridge are preserved as negative forms.

deltidium in the apical part. Sulcus always with median rib, ribs of third order may be developed. Ex terior of dors al valve: dorsal interarea low, strongly curved, and anacline, but clearly catacline in the lower part. Fold often with median furrow. Ribs of third order may be developed on fold. Coarse ornamentation: ribs of first order begin at the apex, ribs of second order develop by bifurcation anterior of the ventral muscle field on the internal mould. Ribs of first order strong, ribs of second order smaller and weaker, those of third order developed only in sulcus or on fold, in juvenile specimens angular becoming rounded in adult stage in cross section. Ribs of second and third order are clearly smaller and finer than ribs of first order giving them the characteristic 'bundled' appearance. 5 to 8 ribs of first order on each flank, including ribs of second order, number may reach 18. Fine growth lamellae in anterior part of both valves. At the middle of shell length the ribs of first order bifurcate or trifurcate. Trifurcation only on the first 4 pairs of ribs next to sulcus and fold, ribs of second order weaker than the ribs of first order (Fig. 4I). Ribs of third order may also develop in sulcus and on fold. Bifurcation on fold and in sulcus on the inner side of the lateral ribs of sulcus and fold (Fig. 5). Micro-ornamentation: capillate with tendency to development of long marginal micro-spines at the edge of each growth lamellae (Fig. 2I). Interior of ventral valve: filling of the ventral umbo extends gently posteriorly over the hinge line. Ventral process small, in juvenile specimens often very sharp, in gerontic stage often
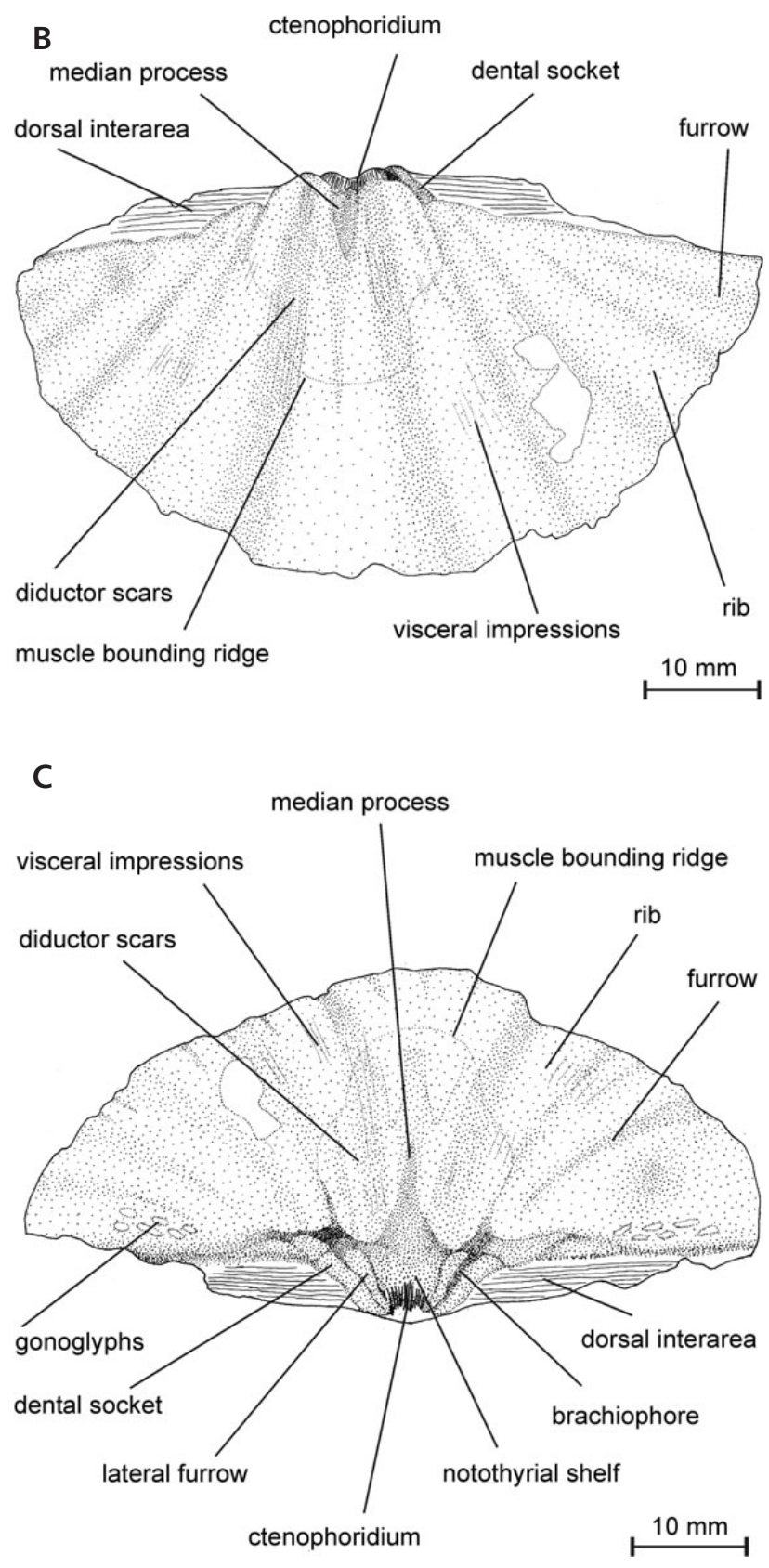

blurred leaving a round indentation on the internal mould. A well developed septal pillow is situated below the ventral process and is laterally bordered by a pair of small ridges after the deltidial lamellae. Lateral apical cavities filled by secondary shell material. Ventral muscle field gently embedded into shell, elongate, and subtrapeziform to subtriangular in gerontic stage. Ventral median septum lacking or weakly developed. Impressions of 1 to 2 ribs on the ventral muscle field. Diductor scars radially arranged. Adductor scars thin and elongated, hardly recognisable on internal mould. Muscle bounding ridge very weakly developed, often only recognisable in juvenile specimens and diminishing in adult specimens. Free portions of dental plates 
wedge-like and embedded into secondary shell material, in juvenile specimens dental plates often thin and longer than in adult stages. Gonoglyphs rarely and only weakly preserved lateral of the ventral muscle field. Sulcus always with median rib. Impressions of ribs of second and rarely third order starting from the flanks of the sulcus bordering ribs. Sulcus bounding ribs not weakened, the first 2 or 3 pairs of ribs remarkably coarser than the following lateral pairs. Impressions of ribs of first order on the internal mould 4 to rarely 5 with ribs of second order often 8 , in rare cases more than 10. Ribs of second order only weakly developed on the internal mould and much weaker developed than ribs of first order. Ribs in juvenile specimens angular in cross section and strongly elevated, in adult stages lower and rounded in cross section due to development of secondary shell material. Multiplication of ribs only anterior of the muscle field impressed on the internal mould. Visceral impressions arranged as radial striae on the surface of the internal mould, mostly lateral of the anterior margin of the muscle field. Interior of dorsal valve: internal mould transverse and without mucronations. Dorsal adductor field embedded into shell material. Cardinalia clearly visible and situated on an elevated shelf that is more or less in the same plane as the interarea. Ctenophoridum situated on a notothyrial shelf and laterally bordered by a pair of furrows leaving a distinct rim on the internal mould that is angular to rounded in cross section. Dental sockets thin and rounded in cross section. Brachiophores low and very thin pointing apically. Crural plates and free portions of crural bases absent, weak indentations lateral of the adductor field may represent remains of crural plates. Median process coarse leaving a deep and coarse furrow on the internal mould that is flattened at its base on the internal mould separating the posterior part of the adductor field. A short myophragm extends out of the adductor field that can be large in rare cases. Dorsal adductor field 'mushroom'-shaped in outline and bordered anteriorly by a fine muscle bounding ridge that leaves a weak furrow on the internal mould. Anterior and posterior pair of adductors clearly differentiable. The posterior pair consists of a 'hippodrome'-like field on each side situated on the fold and the first pair of ribs that may also reach into the second pair of furrows. The posterior adductors are elongated and longer than the anterior adductors. Adductor field situated on the fold, its posterior end is embedded into secondary shell material building two 'horn'-like structures pointing in a posterior direction on the internal mould. Adductors are sometimes impressed as radial striations on the internal mould. Impressions of ribs present anterior of the muscle field but weaker than on the ventral valve consisting almost only of ribs of first order. Striations of visceral impressions preserved in a few specimens. Gonoglyphs preserved as little transverse ridges on the internal mould which are pointing in a lateral direction.
Remarks. - Kaplun in Kaplun \& Krupchenko (1991) erected the genus Multispirifer with its European type species M. solitarius and new taxa from Kazakhstan. Hou \& Su (in $\mathrm{Su} \&$ Hou 1993) realised that the Kazakhstan forms had nothing to do with the European Multispirifer and erected the genus Borealispirifer with the type species B. bifurcatus from Kazakhstan. Talent et al. (2001) considered Kaplun's (1961) taxa of Borealispirifer as species of Struveina, which is erroneous because the two genera possess different micro-ornamentation, capillate versus fimbriate, respectively. In this work, Multispirifer is considered as an isolated branch of delthyridoid spiriferids that is restricted to the Middle Siegenian of Belgium and Germany.

Geographic and stratigraphic occurrence. - See family.

\section{Acknowledgements}

Special thanks are due to Ulrich Jansen, Gerhard Plodowski, and Olaf Vogel (all SMF) for collecting the main part of the material studied from Europe and North Africa. I also thank Ulrich Jansen for giving me access to the brachiopod collections and for fruitful criticism of the manuscript. Technical help was provided by Juliane Eberhardt and Erika Scheller-Wagner (both SMF) and Melissa McMullen (University of Cincinnati, USA). I am very grateful to Mike Reich for kindly supporting me with a working space and literature during a short time research visit in Göttingen and Frank Langenstrassen for discussion of the Eifelian spiriferids (both GZG). The following persons are acknowledged for giving access to their collections and the loan of material: Susan Butts (YPM), Peter Carls (Technische Universität Braunschweig, Germany), Cheng Liwei (IV), Jessica Cundive (MCZ), Lee Davies (NHM), Jed Day (Illinois State University, Normal, USA), Bushra Hussaini and Neil Landman (both AMNH), Ed Landing (NYSM), Gonca Nalcığlu (DEVEC-TR), Mike Reich (GZG), Jann Thompson (USNM), and Namik M. Yalçin (Istanbul University, Turkey). I acknowledge Gordon Baird (State University New York, SUNY Fredonia, USA), Alex J. Bartholomew (SUNY New Paltz, USA), Jed Day (Illinois State University, Normal, USA), and Charles Ver Straeten (New York State Museum, Albany, USA) for guidance in the field. I am grateful to Olga Obut (Trofimuk Institute of Petroleum Geology and Geophysics, Siberian Branch of the Russian Academy of Science, Novosibirsk, Russia) for translation of the Russian literature and to Christian Klug (Paläontologisches Institut und Museum der Universität Zürich, Switzerland) for providing me with Chinese literature. Alan Lord (SMF) improved English of an early draft of the manuscript. The work much benefited from the reviews by Robert B. Blodgett (US Geological Survey, Anchorage, USA), Arthur J. Boucot (Oregon State University, Corvallis, USA), and Michal Mergl (University of West Bohemia, Plzeň, Czech Republic).

This study is part of the DFG (German Science Foundation) Grant JA 987/6-1: 'Biohistoric evolution of spiriferid brachiopods: A model study of a globally distributed Devonian clade' and part of the PPP (Project Based Personnel Exchange 
Programme) project of the DAAD (German Academic Exchange Service) Grant D/06/29290: 'Comparison and correlation of Lower and Middle Devonian sedimentary rocks from the Rhenohercynian Belt (Central Europe) and the Appalachian Basin (Northeastern USA)'. The Lerner Gray Award gave financial support to travel to the United States and work in the collections of the American Museum of Natural History, New York City and the New York State Museum, Albany. The visit to the collection of the Peabody Museum/Yale University, New Haven, Connecticut, USA was financed by one each of Charles Schuchert and Carl O. Dunbar Grants in Aid. The help of Melissa McMullen was financed by the RISE programme (Research Internships in Science and Engineering) of the DAAD. This research received support from the SYNTHESYS Project http://www.synthesys.info/, which is financed by European Community Research Infrastructure Action under the FP6 'Structuring the European Research Area' Programme (GB-TAF-5141).

This is a contribution to the IGCP 499 Devonian land-sea interaction: evolution of ecosystems and climate - DEVEC. Specimens from Turkey were sampled in the frame of the 'Devonian ecosystems and climate of Turkey - DEVEC-TR', TUBITAK Joint Research and Development project.

\section{References}

AMSDEN, T.W. 1963. Articulate brachiopods of the Frisco Formation (Devonian), 1-238. In AMSDEN, T.W. \& VENTRESS, W.P.S. (eds) Early Devonian brachiopods of Oklahoma. Bulletin of Oklahoma Geological Survey 94.

BARRANDE, J. 1879. Systême silurien du centre de la Bohême. Recherches Paléontologïques. Classe des Mollusques. Ordre des Brachiopodes. 5. 226 pp. Published privately, Prague \& Paris.

BENEDETTO, J.L. 1984. Les brachiopodes Dévoniens de la Sierra de Perija (Venezuela). Systématique et implications paléogéographiques. Biostratigraphie du Paléozoïque 1, 1-191.

Billings, E. 1874. Geological Survey of Canada. Palaeozoic fossils, Vol. II, Part 1. 144 pp. Dawson Brothers, Montreal.

BouCOT, A.J. 1959. Brachiopods of the Lower Devonian rocks at Highland Mills, New York. Journal of Paleontology 33, 727-769.

Boucot, A.J. 1960a. A new Lower Devonian stropheodontid brachiopod. Journal of Paleontology 34, 483-485.

BoUCOT, A.J. 1960b. Implications of Rhenish Lower Devonian brachiopods from Nova Scotia. International Geological Congress XXI session, Part XII, 129-137.

BouCOT, A.J. 1975. Evolution and extinction rate controls. 426 pp. Elsevier, Amsterdam.

Boucot, A.J. \& BLODGETT, R.B. 2001. Silurian-Devonian biogeography, 335-344. In BRUNTON, C.H.C., COCKS, L.R.M. \& LONG, S.L. (eds) Brachiopods Past and Present. The Systematics Association Special Volume Series 63. Taylor \& Francis, London \& New York.

Boucot, A.J., MACDONALD, G.J.F., MiLton, C. \& THOMPSON, J.B. Jr. 1958. Metamorphosed middle Paleozoic fossils from Central Massachusetts, Eastern Vermont, and Western New
Hampshire. Bulletin of the Geological Society of America 60, 855-870.

DO1 10.1130/0016-7606(1958)69[855:MMPFFC]2.0.CO;2

BRICE, D. 1982. Brachiopods du Dévonien Inférieur et Moyen des Formations de Blue Fiord et Bird Fiord des Iles Arctiques Canadiennses. Geological Survey of Canada Bulletin 326, $1-175$.

Bultynck, P. \& SOERS, E. 1971. Le Silurien supérieur et le Dévonian inférieur de la Sierra de Guadarrama (Espagne Centrale). Bulletin de Institute Royal des Sciences naturelles de Belgique 47(1), 1-22.

CARLS, P. 1969. Die Conodonten des tiefen Unter-Devons der Guadarrama (Mittel-Spanien) und die Stellung des Grenzbereiches Lochkovium/Pragium nach der rheinischen Gliederung. Senckenbergiana lethaea 50, 303-355.

CARLS, P. 1985. Howellella (Hysterohowellella) knetschi (Brachiopoda, Spiriferacea) aus dem tiefen Unter-Gedinnium Keltiberiens. Senckenbergiana lethaea 65, 297-326.

CARLS, P. 1986. Neue Arten von Vandercammenina und Hysterolites (Brachiopoda, Acrospiriferinae; Devon). Senckenbergiana lethaea 67, 33-41.

CARLS, P. 1987. Ein Vorschlag zur biostratigraphischen Redefinition der Grenze Gedinnium/Siegenium und benachbarter Unter-Stufen. 1. Teil: Stratigraphische Argumente und Korrelation. Courier Forschungsinstitut Senckenberg 92, 77-121.

CARLS, P. 1996. Keltiberien. In K. WEDDIGE, K. (ed.) Beiträge zu Gemeinschaftsaufgaben der deutschen Subkommission für Devon-Stratigraphie, 1: Devon-Korrelationstabelle. Senckenbergiana lethaea 76, 278, column R142di96.

CARLS, P. \& HEDDEBAUT, C. 1980. Les Brachiopodes Spiriferida. In Plusquellec, Y. (ed.) Les Schistes et Calcaires de l'Armorique (Dévonien inférieur, Massif Armoricain); Sédimentoloige - Paléontologie - Stratigraphie. Mémoires de Société géologique et mineralogique de Bretagne 23, 215-222.

CARLS, P., MEYN, H. \& VESPERMANN, J. 1993. Lebensraum, Entstehung und Nachfahren von Howellella (Iberohowellella) hollmanni n. sg., n. sp. (Spiriferacea; Lochkovium, UnterDevon). Senckenbergiana lethaea 73, 227-267.

CARLS, P. \& VALENZUELA-Ríos, J.I. 2002. Early Emsian Conodonts and associated shelly faunas of the Mariposos Fm (Iberian Chains, Aragón, Spain), 315-333. In GARCÍA-LÓPEZ, S. \& BASTIDA, F. (eds) Palaeozoic conodonts from Northern Spain. Instituto Geológico y Minero de España, serie Cuadernos del Museo Geominero, Madrid.

CARTER, J.L., JOHnSON, J.G., GOURVEnNEC, R. \& Hou HonGFEI 1994. A revised classification of the spiriferid brachiopods. Annals of the Carnegie Museum 63(4), 327-374.

ClARKE, J.M. 1908. Early Devonic History of New York and Eastern North America; Part I. New York State Museum, Memoir 9, 1-366.

ClARKE, J.M. 1909. Early Devonic History of New York and Eastern North America; Part II. New York State Museum, Memoir 9, $1-250$.

COMPTE, P. 1938. Brachiopodes dévoniens des gisements de Ferrones (Asturies) et de Sabero (Léon). Annales de Paléontologie 27, 6-49. 
CONRAD, T.A. 1839. Descriptions of new species of organic remains. $3^{\text {rd }}$ Annual Report of the New York State Geological Survey, 57-66.

COOPER, G.A. 1942. New genera of North American brachiopods. Journal of Washington Academy of Sciences 32(8), 228-235.

COOPER, G.A. 1944. Phylum Brachiopoda, 277-365. In SHIMER, H.W. \& SHROCK, R.R. (eds) Index Fossils of North America. Wiley \& Sons, New York.

DAHMER, G. 1934. Die Fauna der Seifener Schichten (Siegenstufe). Abhandlungen der Preußischen geologischen Landesanstalt N.F. 147, 1-91.

DAHMER, G. 1935. Revision der Fauna von Menzenberg (Siegen-Stufe). Decheniana 91, 135-150.

DAWsON, J.W. 1868. Acadian Geology. - The geological structure, organic remains of Nova Scotia, New Brunswick, and Prince Edward Island. $2^{\text {nd }}$ edition, revised and enlarged. 694 pp. Macmillan \& Co., London.

DrevermanN, F. 1904. Die Fauna der Siegener Schichten von Seifen unweit Dierdorf (Westerwald). Palaeontographica 50, 229-287.

DROT, J. 1964. Rhynchonelloidea et Spiriferoidea siluro-dévoniens du Maroc pré-saharien. Notes et Mémoires du Service Géologique du Maroc 178, 1-288.

FAgERSTROM, J.A. 1961. The fauna of the Middle Devonian Formosa Reef limestone of southwestern Ontario. Journal of Paleontology 35, 1-48.

FREDERIKS, G.N. 1924. Paleontologitcheskie ztoudy. 2: O verkhne kamennougholnykh spiriferidakh Ourala. Ivestyia geologicheskogo Komiteta 38(3), 295-324. [in Russian]

GARCÍA-ALCALDE, J.L. 2004. Lower Devonian Delthyridoidea (Brachiopoda, Delthyridina) of the Cantabrian Mountains (N Spain). Bulletin de l'Institut Royal des Sciences Naturelles de Belgique 74, 9-38.

GEDIK, İ., YILMAZ, İ., KOZLU, H. \& YALÇÝN, M.N. 2005. Devonian in Northwestern Turkey, 53-61. In Devonian Land-Sea Interaction: Evolution of Ecosystems and Climate in the Devonian DEVEC, IGCP Project-499 - International Workshop Depositional Environments of the Gondwanan and Laurasian Devonian, 26 September-3 October 2005, Turkey. Abstracts \& Field Guide Book. Istanbul.

GIEBEL, C.G. 1858. Die Silurische Fauna des Unterharzes nach Herrn C. Bischoff's Sammlung. Abhandlungen des Naturwissenschaftlichen Vereines der Provinzen Sachsen und Thüringen 1, 25-70.

GOURVENNEC, R. 1989. Brachiopodes Spiriferida du Dévonien inférieur du Massif Armorican. Systématique, paléobiologie, évolution, biostratigraphie. Biostratigraphie du Paléozö̈que 9, $1-281$.

GourvenNeC, R. \& CARTER, J.L. 2007. Spiriferida and Spiriferinida, 2772-2796. In SELDON, P.A. (ed.) Treatise on Invertebrate Paleontology, Part H, Brachiopoda 6 (revised). Geological Society of America \& University of Kansas, Lawrence, Kansas.

Gradstein, F.M., OGG, J.G. \& SMITH, A.G. 2004. A Geologic Time Scale 2004. 589 pp. Cambridge University Press, Cambridge.
HALAMSKI, A.T. 2004. Faunistic analysis of the Middle Devonian Brachiopods from the Northern part the Holy Cross Mountains. 354 pp. Unpublished Ph.D. thesis, Polish Academy of Sciences, Institute of Paleobiology, Warsaw, Poland \& Université Lyon I, U.F.R. des Sciences de la Terre, Lyon, France.

HALL, J. 1860. Descriptions of new species of fossils (from the Hamilton Group of western New York, with notices of others from the same horizon in Iowa and Indiana). $13^{\text {th }}$ Annual Report of the New York State Cabinet of Natural History. Contributions to Palaeontology, 76-94.

HALL, J. 1867. Descriptions and figures of the fossil Brachiopoda of the upper Helderberg, Hamilton, Portage and Chemung Groups. New York Geological Survey, Palaeontology of New York 4, 1-428.

HAVLÍČEK, V. 1959. Spiriferidae v českém siluru a devonu (Brachiopoda). Rozpravy Ústředního ústavu geologického 25, 1-275.

HAVLÍČEK, V. 1994. Immigration of the Rhenish-type and Australian brachiopod stocks into the Prague basin (Central Bohemia) in the Lowest Emsian (Lower Devonian). Věstník Českého geologického ústavu 69(4), 41-45.

Hou HongfeI 1959. Spiriferid fossils from Lower Devonian (Eifelian) in Guangxi. Acta Palaeontologica Sinica 7(6), 450-475. [in Chinese with Russian and English abstracts]

HOU HONGFEI \& XIAN SIYUAN 1975. The Lower and Middle Devonian brachiopods from Guangxi and Guizhou. Professional Papers of Stratigraphy and Palaeontology 1, 1-85. [in Chinese]

HÜFFNER, E. 1916. Beiträge zur Kenntnis des Devons von Bithynien. Jahrbuch der Königlich preußischen geologischen Landesanstalt, für 1916, 37(1), part 1, 261-357.

IVANOVA, E.A. 1972. Osnovnyye zakonomernosti evolyutsee spiriferid (Brachiopoda). Paleontologicheskii Zhurnal 1972(3), 28-42. [in Russian]

JANSEN, U. 2000. The Early Devonian genus Acrospirifer. A taxonomic odyssey. The Millenium Brachiopod Congress, Abstracts. London.

JAnSEN, U. 2001a. Morphologie, Taxonomie und Phylogenie unter-devonischer Brachiopoden aus der Dra-Ebene (Marokko, Prä-Sahara) und dem Rheinischen Schiefergebirge (Deutschland). Abhandlungen der Senckenbergischen Naturforschenden Gesellschaft 554, 1-389.

JANSEN, U. 2001b. On the genus Acrospirifer Helmbrecht et Wedekind, 1923 (Brachiopoda, Lower Devonian). Journal of the Czech Geological Society 46(3-4), 131-144.

JANSEn, U., Becker, G., Plodowski, G., Schindler, E., Vogel, O. \& Weddige, K. 2004. The Emsian to Eifelian near Foum Zguid (NE Dra Valley, Morocco), 19-28. In EL HASSANI, A. (ed.) Devonian neritic-pelagic correlation and events in the Dra Valley (Western Anti-Atlas, Morocco). International Meeting on Stratigraphy, Rabat, March 1-10, 2004. Documents de l'Institut Scientifique 19.

JANSEN, U., LAZREQ, N., PlODOWSKI, G., SCHEMM-GREGORY, M., SCHINDlER, E. \& WedDige, K. 2007. Neritic-pelagic correlation in the Lower and basal Middle Devonian of the Dra Valley (S Anti-Atlas, Moroccan Pre-Sahara). The Geological Society, London, Special Publication 278, 9-37.

DOI $10.1144 / \mathrm{SP} 278.2$ 
JOHNSON, J.G. 1970. Great Basin Lower Devonian Brachiopods. The Geological Society of America, Memoir 121, 1-421.

JoHnson, J.G. \& HOU HONGFEI 2006. Delthyridoidea, 1825-1847. In KAESLER, R.L. (ed.) Treatise on Invertebrate Paleontology, Part H, Brachiopoda 5 (revised). Geological Society of America \& University of Kansas, Lawrence, Kansas.

JOHnSON, J.G., KLAPPER, G. \& SANDBERG, C.A. 1985. Devonian eustatic fluctuations in Euramerica. Geological Society of America Bulletin 96, 567-587. DOI 10.1130/0016-7606(1985)96<567:DEFIE >2.0.CO;2

JONES, B. \& BouCOT, A.J. 1983. Spiriferida from the Lower Devonian strata of Southwest Ellesmere Island, Arctic Canada. Journal of Paleontology 57, 327-346.

KAPLUN, L.I. 1961. Brakhiopody nizhnego devona severnogo pribalkhashya, 64-114. In Materialy po geologii i poleznym iskopaemym Kazakhstana. Stratigrafiya i paleontologiya. Moscow. [in Russian]

KAPLUN, L.I. \& KRUPCHENKO, N.V. 1991. Brakhiopody nizhnego i srednego devona Dzhungaro-Balkhashskoi provintsii, 111-147. In Dubatolov, V.N. \& Stukalina, G.A. (eds) Biostratigrafiia nizhnego i srednego devona Dzhungaro-Balkhashskoi provintsii. Institut Geologii i Geofiziki (Akademiia Nauk SSSR), Nauka, Moscow. [in Russian]

KAYSER, E. 1878. Die Fauna der ältesten Devon-Ablagerungen des Harzes. Abhandlungen der geologischen Special-Karte Preußischer Thüringischer Staaten 2(4), I-XXXIII + 1-295.

KAYSER, E. 1889. Die Fauna des Hauptquarzits und der Zorger Schiefer des Unterharzes. Abhandlungen der Preußischen geologischen Landesanstalt N.F. 1, 1-139.

KAYSER, E. 1900. Devon-Fossilien vom Bosporus und von der Nordküste des Marmara-Meeres (zwischen Pendik und Kartal). Beiträge zur Paläontologie und Geologie ÖsterreichUngarns und des Orients. Mittheilungen des Paläontologischen Institutes der Universität Wien 12, 27-41 [1-15].

KozŁowsKI, R. 1946. Howellella, a new name for Crispella Kozlowski, 1929. Journal of Paleontology 20, 295.

KRANTZ, A. 1857. Über ein neues bei Menzenberg aufgeschlossenes Petrefakten-Lager in den devonischen Schichten. Verhandlungen des Naturistorischen Vereins Preussischen Rheinlande und Westphalens 3, 150-152.

LidDle, R.A, HARRIS, G.D. \& Wells, J.W. 1943. The Rio Cachiri section in the Sierra de Perijá. Bulletins of American Paleontology 27(108), 27-108.

MAY, A. 1988. Über Vandercammenina (Brachiopoda: Spiriferacea) aus dem Mittel-Devon des Sauerlandes (Rheinisches Schiefergebirge). Hercynica 4(1), 15-23.

MERRIAM, C.W. 1940. Devonian stratigraphy and paleontology of the Roberts Mountains region, Nevada. Geological Society of America, Special Paper 25, 1-114.

MEYER, O.E. 1913. Die Devonischen Brachipoden von Ellesmereland, Report of the Second Norwegian Arctic Expedition in the 'Fram' 1898-1902. Videnskabs-Selskabet i Kristiania 29, $1-43$.

MichARD, A. 1976. Eléments de Géologie Marocaine. Notes et Mémoires du Service Géologique 252, 1-408.
MiLleR, S.A. 1889. North American Geology and Paleontology. 664 pp. Western Methodist Book Concern, Cincinnati.

MuIR-WooD, H.M. 1925. Notes on the Silurian braciopod genera Delthyris, Uncinulus, and Meristina. Annals and Magazine of Natural History, series 9, 15, 83-95.

Oehlert, D. \& Davoust, P. 1879. Sur le Dévonien du départment de la Sarthe. Bulletin de la Société géologique de France, $3^{e}$ série 7, 697-717.

PaeckelmanN, W. \& Sieverts, H. 1932. Neue Beiträge zur Kenntnis der Geologie, Palaeontologie und Petrographie der Umgebung von Konstantinopel. 1. Obersilurische und devonische Faunen der Prinzeninseln, Bithyniens und Thraziens. Abhandlungen der Preußischen geologischen Landesanstalt 142, 1-79.

PHILLIPS, J. 1841. Figures and description of the Palaeozoic fossils of Cornwall, Devon and West Somerset. xii +231 pp. Longman \& Co., London.

PITRAT, C.W. 1965. Spiriferidina, H667-H728. In MoORE, R.C. (ed.) Treatise on Invertebrate Paleontology, Part H, Brachiopoda, Vol. 2, Geological Society of America \& University of Kansas, Lawrence, Kansas.

QUIRING, H. 1915. Beiträge zur Kenntnis der Spiriferenfauna des Mitteldevons der Eifel. Jahrbuch der Königlich preußischen Landesanstalt für 1914, 35(1), 327-335.

SCHEMM-GREGORY, M. 2007. The Lower Devonian brachiopod genus Acrospirifer Helmbrecht and Wedekind, 1923 - globally distributed or highly endemic? Subcommission on Devonian Stratigraphy and IGCP 499 Devonian Land Sea Interaction: Devonian Global Change: compelling changes in the Devonian world, highlighting new findings in the terrestrial and marine biomes: fish, invertebrtes, plants, terrestrial vertebrates, global warming, mass extinction, bolide strikes, and global correlation. Program and Abstracts; Eureka, Nevada, 9-17 September 2007, 78-79.

SCHEMM-GREGORY, M. 2008a. A new species of Filispirifer (Brachiopoda: Delthyridoidea) from the Dra Valley, Morocco (Lower Devonian). Zootaxa 1739, 53-68.

SCHEMM-GREGORY, M. 2008b. The phylogeny of delthyridoid spiriferids (Brachiopoda, Devonian) - A new interpretation, 109-110. In KiM, I.A., SAlimova, F.A. \& MeShCHANKINA, N.A. (eds) Global Alignments of Lower Devonian Carbonate and Clastic Sequences (IGCP 499 project / SDS joint field meeting): Contributions of International Conference. August 25-September 3, 2008. Kitab State Geological Reserve, Uzbekistan.

SCHEMM-GREGORY, M. 2008c. A new delthyridoid spiriferid genus from the Dra Valley, Morocco, and its phylogenetic affinities (Brachiopoda, Lower Devonian). Paläontologische Zeitschrift 82, 386-402.

SCHEMM-GREGORY, M. in press. A new spiriferid genus and its phylogenetic position within the Delthyridoidea (Brachiopoda, Lower Devonian). Neues Jahrbuch.

SCHMIDT, H. \& TRUNKO, L. 1965. Die Basis des Givet im Bereich der Lenneschiefer. Fortschritte der Geologie von Nordrhein-Westfalen 9, 755-806.

SCHUCHERT, C. 1929. Classification of brachiopod genera, Fossil 
and Recent, 10-25. In POMPECKJ, F.F. (ed.) Fossilium Catalogus 1: Animalia, pars 42: Brachiopoda. W. Junk, Berlin.

SCUPIN, H. 1900. Die Spiriferen Deutschlands. Palaeontologische Abhandlungen, N.F. 4, 207-344.

SOLLE, G. 1953. Die Spiriferen der Gruppe arduennensis-intermedius im rheinischen Devon. Abhandlungen des hessischen Landesamtes für Bodenforschung 5, 1-156.

SOLLE, G. 1971. Brachyspirifer und Paraspirifer im Rheinischen Devon. Abhandlungen des hessischen Landesamtes für Bodenforschung 59, 1-163.

SPRIESTERSBACH, J. 1915. Neue und bekannte Versteinerungen aus dem rheinischen Devon, besonders aus dem Lenneschiefer. Abhandlungen der Preußischen geologischen Landesanstalt, N.F. 80, 1-80.

STEININGER, J. 1853. Geognostische Beschreibung der Eifel. 144 pp. Lintz'sche Buchhandlung, Trier.

Su YANGZHEN \& Hou Hongfei 1994. The Early Devonian spiriferid brachiopod Borealispirifer n. gen. from the Balkash-Mongolia-Okhotsk Region, 139-147. In YANG ZUNYI (ed.) Stratigraphy and Palaeontology of China 2. 240 pp. Geological Publishing House, Beijing.

SWARTZ, F.M. 1929. The Helderberg Group of parts of West Virginia and Virginia. Shorter Contributions to General Geology, Professional Paper 158-C, 27-75.

TAlent, J.A., Gratsianova, R.T. \& Yolkin, E.A. 2001. Latest Silurian (Pridoli) to Middle Devonian (Givetian) of the Asia-Australia hemisphere: rationalization of brachiopod taxa and faunal lists; stratigraphic correlation chart. Courier Forschungsinstitut Senckenberg 236, 1-221.

TERMieR, H. \& TERMieR, G. 1949. Essai sur l'évolution des Spiriféridés: Maroc. Service Géologique, Division de Mines et Géologie, Notes et Mémoires 74, 85-1123.

THIENHAUS, R. 1940. Die Faziesverhältnisse im Südwestteil der
Attendorner Mulde und ihre Bedeutung für die Stratigraphie des bergisch-sauerländischen Mitteldevons. Abhandlungen der Reichsstelle für Bodenforschung, N.F. 199, 1-77.

VAnderCAmmen, A. 1963. Spiriferidae du Dévonien de la Belgique. Mémoires de l'Institut Royal des Sciences Naturelles de Belgique 150, 1-170.

VERNEUIL, E. de 1850. Tableau des fossiles du terrain dévonien du département de la Sarthe. Bulletin de la Société Géologique de France 7 (série 2), 778-787.

Verneuil, E. de 1869. Appendice a la Faune Dévonienne du Bosphore. L'Asie mineure, Paléontologie, 425-495.

WAAGEN, W.H. 1883. Salt Range fossils, Part 4(2) Brachiopoda. Palaeontologica Indica, Memoires 13, 391-546.

WANG YÜ, LIU DiYONG, WU QI \& Zhang ShILAN 1974. Brachiopoda (Devonian), 240-247. In Nanking Institute of Geology and Palaeontology (ed.) A Handbook of the Stratigraphy and Paleontology in Southwest China. Science Press, Beijing. [in Chinese]

WANG YÜ \& RONG JIA-YU 1986. Yukiangian (Early Emsian, Devonian) brachiopods of the Nanning-Liujing District, central Guangxi, southern China. Palaeontologica Sinica 172(22), 1-282. [in Chinese with English abstract]

Williams, A. \& BRUNTON, C.H.C. 1997. Morphological and anatomical terms applied to brachiopods, 423-440. In KAESLER, R.L. (ed.) Treatise on Invertebrate Paleontology, Part H, Brachiopoda. Revised. Volume 1: Introduction. Geological Society of America \& University of Kansas, Boulder, Colorado \& Lawrence, Kansas.

ZhANG YAN 1983. Late Palaeozoic Brachiopods, 244-425. In Zhang YAn, Fu LiPU \& Ding PEIZHEN (eds) Palaeontological Atlas of Northwest China, Shaanxi, Gansu and Ningxia Provinces. Part 2, Upper Palaeozoic. Geological Publishing House, Beijing. [in Chinese] 